

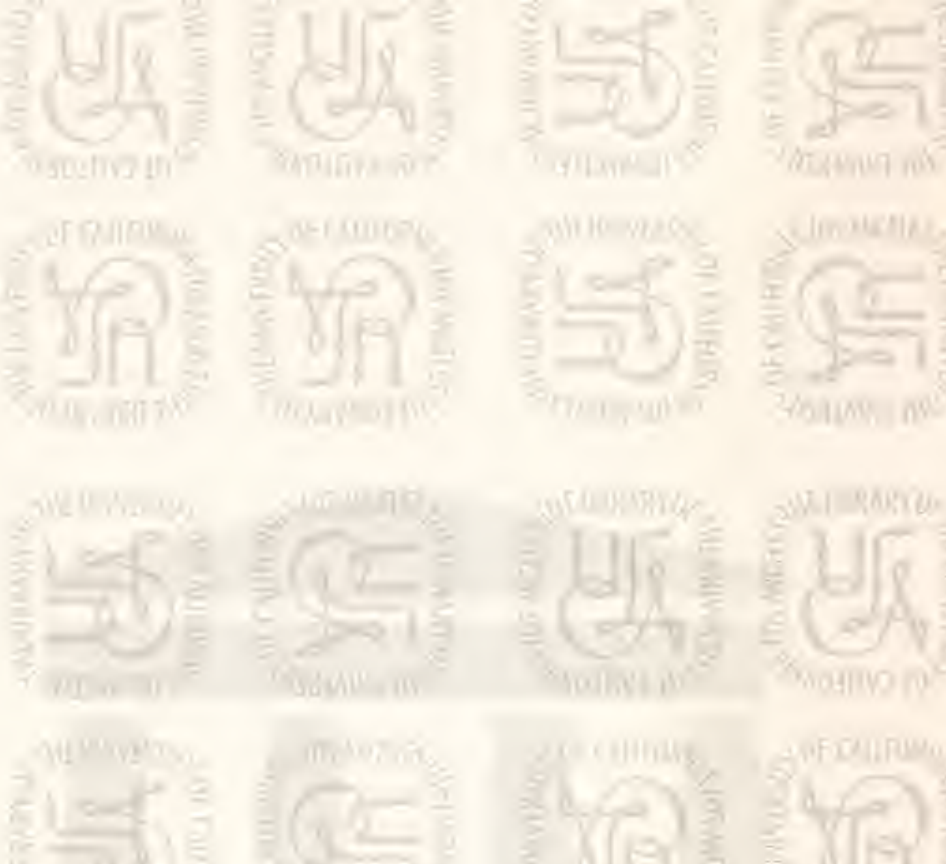

Digitized by the Internet Archive in 2008 with funding from Microsoft Corporation
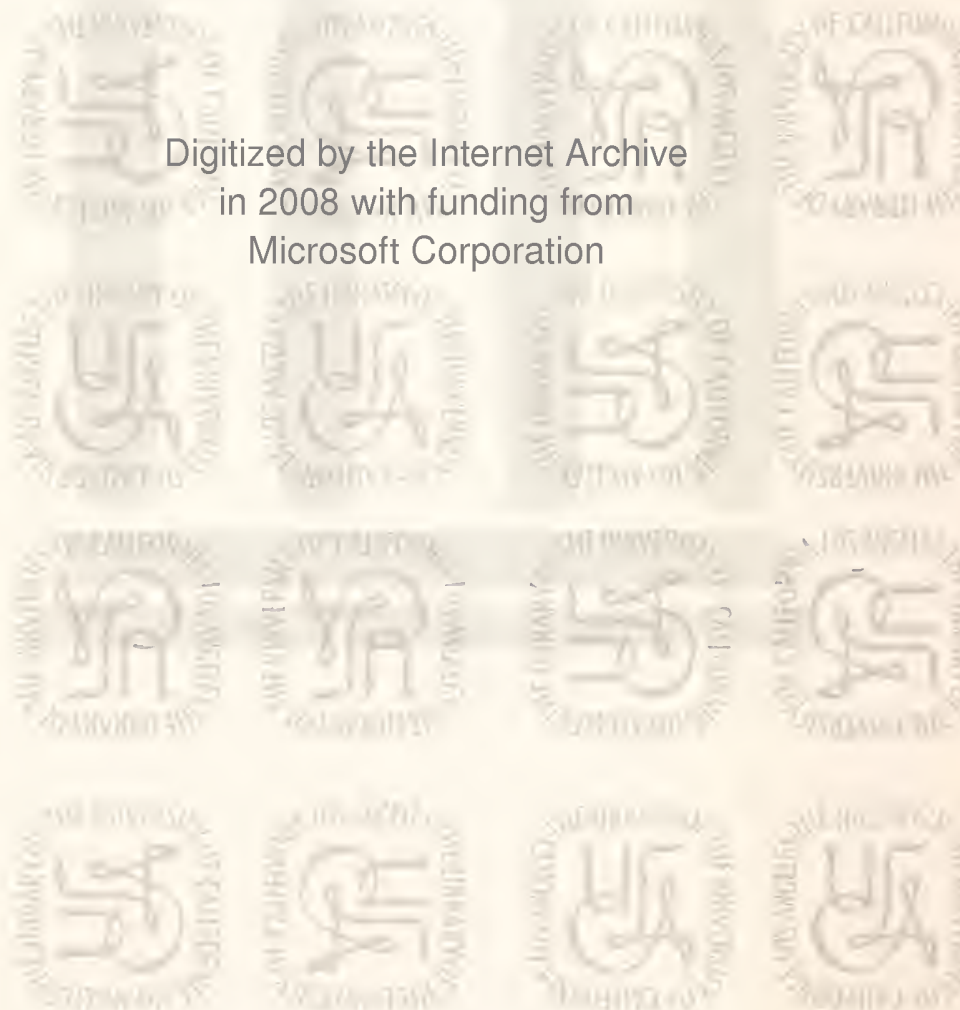

http://www.archive.org/details/travelsinupperlo03sonn 





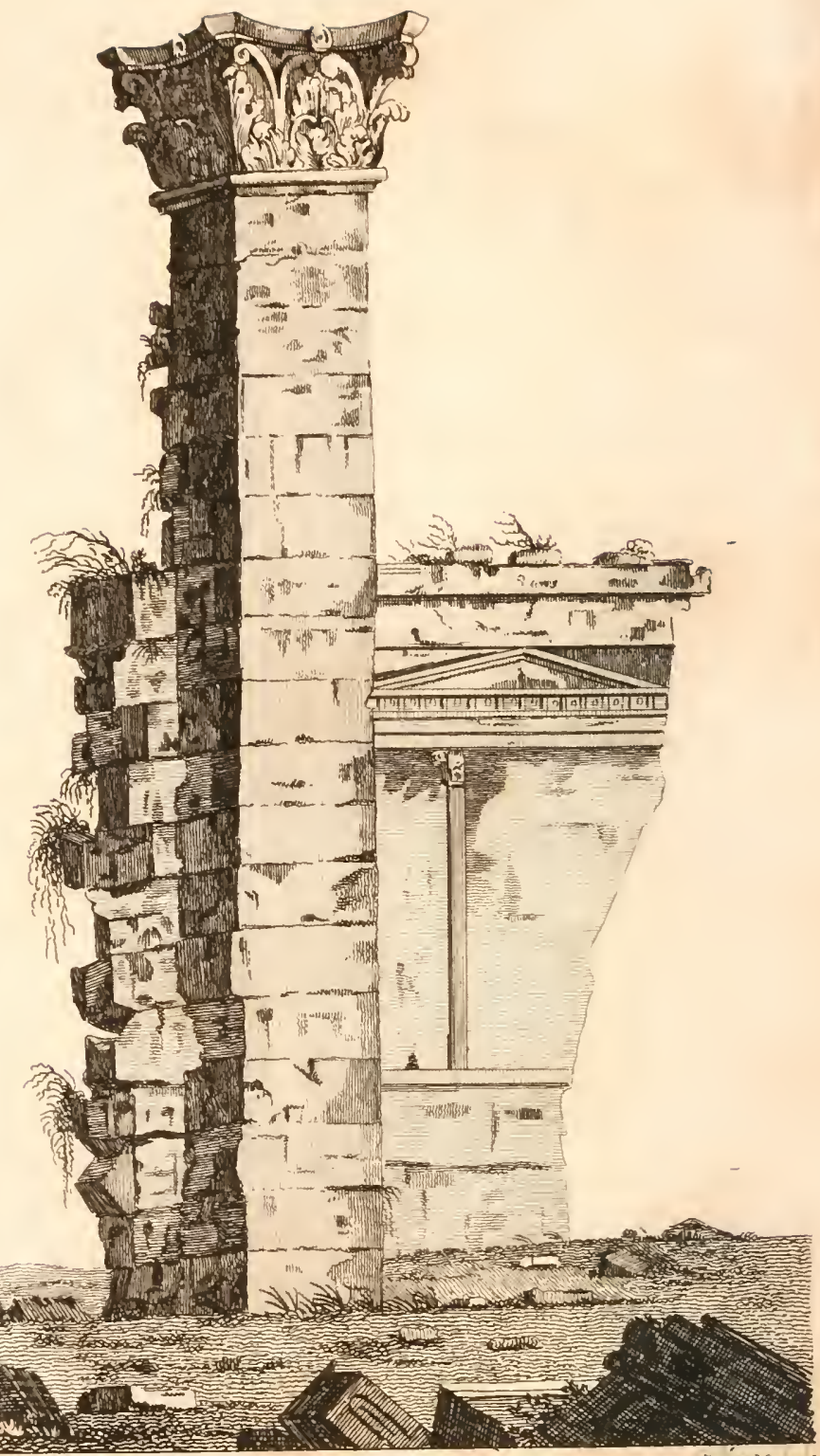

$$
\text { 'Yotumen of Strance. }
$$




\title{
TRAVELS
}

IN

UPPER AND LOWER EGYPT:

UNDERTAKEN EY ORDER OF

THE GLD GOVERNMENT OF FRA:CE;

\author{
BY \\ C. S. SONNTNT,
}

ENGINEER IN THE FRENCH NAYY, AND MEMBER OF SEVERAL SCIENTIFIC AND LITERARY SOCIETIES.

ILLUSTRATED WITH FORTY ENGRAVINGS;

CONSISTIXG OF

Portraits, Views, Plans, a Geographical Chart, Antiquities, Plants, Animals, \&c.

Drawn on the Spot, under the Author's Irspection.

...... Tolerantia rerum

Spernebat cunctas insuverata minas.

Vertice nudato, ventos pluviusque ferebam.

Non in:hi solstitium, non grave frigus erat.

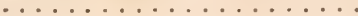

Quamvis exiguo poteram requiescere somno,

Lt quamvis modico inembra forere cibu.

Corn. Gallus, Epig. I. Senect. Descr.

Transiated from the French,

BY HENiRY HUNYER, D. D.

NEIV EDITION.

IN THREE VOLUMES.

VOL. III.

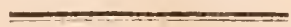

LONDON :

PRINTED FOR JOHN STOCKDALE, PICCADILLX. 1807 . 
S. Los Na1.2, Printer, Little Queen Street, Londor. 


\title{
C O N TENTS.
}

\author{
VO L. III.
}

\section{Chap. XXXVIII.}

Project of a journey into Alyssinia-The manner in which the author supplied the insufficiency of the means wherewith government furnished him-Disgust with which travellers are oppressed-Preparation for a journey into Upper Egypt-Facility of the eastern nations in speaking languages-Syrian interpreter -Boulac-Curlews-Balhs-Embabé-Butter-Lupin-Ancient Cairo-Joseph's sranaries-Aqueduct-Nilometer-Gizals - I

\section{CHAP. XXXIX.}

Departure from ancient Cairo-Scheick Itmann-Quarries-Monasteries-Fishesandbirds-Whirlwinds and water-spouts-Watering of the ground -Particular's of the voyage-Houses of the villages of Upper Egypt-Carthomus-Sudden gust of wind from the south-Benisouef-Accident on the voyage-Mountains-Manner in which the women of Upper Esypt carry water - 20 


\section{Chap. XL.}

Miniet-Bardacks-Ancient city-Manner of selting fractured limbs-Rain and squalls of windScheick Abadé-Ancient city of Antinoë-Catacombs-Mellavoni-Mountain of AboufechaMunfelout-Convent of the Pulley-Large boat -Siout-Jackal-Grottoes of the MountainsBirds of Siout

37

\section{Chay. XLí.}

Practice of phis'sic in Ergy-Peculiarities on this suljoit-Eigyptian physicians-Species of leprosy - Fiolent disorder of the eyes, with which the author reas athachicat-Rents of the houses in Egypt - Circumcision-Rain in Upper Egypt-Researches in quest of treasure-Perfidy of the Syricn intertreter

\section{Chap. XLII.}

Preparations for a journey to Semaar-Conspiracy betwen the chilef of the caravan of Nubia and the Syriun interpreter, in assassinate the anlhor, obliged to renounce the journey into Aly'ssiniaCaravons of the Nubians-Monkeys-Perroquets -Nubians - Visit to a camp of Bedouins-Percnopters-Cophts-Repast-Rubbers for the feet - Apricots - Vater-melons - Melons-Dates Hemp, its intoxicating quality 


\section{Chap. XLIII.}

Tomieh - Aboutigé - Robbers - Tahta - CophtSick man, and the method in which the author repressed his arrogance-Catholic Cophts-The persecutions which they suffer-Engraved stones and medals-Apples-Melons-Doun Sä̈di-Species of palm-tree of Thebain-Different species of the leprosy

95

\section{Chap. XLIV.}

Soutuaje-Italian monks of the Society de Propagandâ Fide, their incivility, their mode of life, their house-Letler of their superior-Catholic Cophts - Echmimm - Panopolis - Catholic priest-Antique figure-Mosque-Plains of EchnimmMelons-Courteanns-Chrysomal. - $\quad$ II4

\section{Chap. XLV.}

Italian monks - Cophtish curé-Excessive heatBardis-Donn-Monks of Farschout-Arabian frince-Farschout-Author's boat put in requisition-Justice which the Arabian prince ordered to le done him-Intolerance on the part of a Mamelus-Departure from Salaet-Rafts of pastécasCrocodile-Hou, Diospolis-parva-Kafr Essäad - Riafts of earthenvare-Birds-Dogs-Danserous passage of the Nile-Accident which befell the author's lioat-El Bal, another dangerous place 


\section{Cha . XLVI.}

Tentyris-Dendera-Emir-Temple of Isis-Description of several eviraordinary figures-Trochilus of the ancients-Colours-Egyptian village built upon the ancient temple-Efforts of barbarism to destroy it-Figilance in the boat-Fruits - Silnation of Dendera

\section{Chap. XlViI.}

Alnoub-Ballas - Earthen pols-Water-melon-Néguadé-Earlinquake-The hyenu-Wild and domestic animals-The tiger-The lion-The hippopolanus-The bear-Boat anchor-RobbersThe stork-The pelican-Ismän-Abon-Ali: description of him; his plan 10 make himself young again

\section{Chap. Xlvili.}

Retron 10 Néguadé-Swelling of the Nile-Waterspimers-Kous-Remains of the city of ApolloMokka coffee- Fertility of the soil in Upper Egypt - Its agriculture-Granivorous birds-Swallows - Laundress - Ravens - Flies - Bugs - Insects still more disgusting-Ichncumon fly-Drone bee - Wasp - Scorpion-Crab-Degeneracy of the people of Egypt-IVomen of Thebäs - Those who harse embraced the Catholic faith, have become subject to foreigrz monks-Effects of jealonsy 
in women-Purgatives - Senna-Tenereal dis. eases-Mastich

\section{Chap. XLIX.}

The effects of missions in Eigypt-Character of the European monks who reside there-Perfily of those of Néguadé-The author's farewell to IsmanAbou-Ali-The gardens of Kous-Citron-lreesGrapes - Melons-Water-melon-Dates-Doum -The real acacia-Sésame, its oil, node of preparing it-Diseases of the skin at the period of the sicelling of the Nite

214

\section{Chap. L.}

Treachery of a Coph-Character of the men of that nation-Dungerous underhand dealings which oblige the Author 10 give up the voyage of the Red Sea-Wasp-New war in Upper Egyph-ITestern side of the ancient cily of Thebes-GourneiWicked men by whom that rillage is intabitedFragments of antiquity-Disagreealile nightit passed at Gournei-A sick man-Physician of the country - Ronte from Gournei 10 Néguadé - 230 Chap. LI.

Copht of Kous-Sheep of Yemen-Sheep of EigyptGoats-Hogs-Motives which have induced the Egyptians to exclude these animals from bing a part of their food-Crocodile-Lizard-Fragments of ancient stones and glasses-Slones antidotes to poison

Chap. 
viii

Chas. LII.

Kenmé - Koft - Dendera-Kilhé - Commolions Surges of the Nile-Pirates-Saht-BélanéBirds - Girgé - I taliun nonks - Mershé-Guépiers-Tahta-General rebellion in this districtVenereal diseases-Fevers-C I ornis-Bloody piles - Flies - Irhneunon fites - Scorpion-LisardsBoat - Kau-el Kebir - Weevils - Skirmish betroen the Arabs-Repairs of the ban-Aboutigé -Courteanis-Dirt-eaters-Muriflout 264

\section{Chap. LIII.}

Turkish Aga-Mecticine of the Egy-tions-Armiy of Cairo-Miussulman priesis-Bread of lentilsLisards-Bout-Dragon-fies-Guals and water-spinners-Winds-Egyptiun sailors-Mountains-Unpleasant adventure, and ble method by sohich the author extricuted himself-Chuins of moantains, and ohservations respecting themQuariy of white lime-The petican-PyramidsBirds-Dïr Ettin _ - $\quad$ - $\quad 285$

\section{Chap. LIV.}

Glance on the expedition of the French into EgyptJourney from Cairo to Russella-IVatering-machines-Loss of several animals-Altack of the consul of Rossetra by the Bedonins-Birds of passage-Hilgp-hog-Frogs--Rreds-MastichRamadan-Departure from Alexantria - 349 


\section{TRAVELS}

IN

\section{UPPER AND LOWER EGYPT.}

\section{CHAP. XXXVIII.}

Project of a journey into Alyssinia-The manner in which the author supplied the insufficiency of the means wherewith government furnished him-Disgust with which travellers are oppressed-Preparation for a journey into Upper Egypt-Facility of the easlern nations in speaking languages-Syrian interpreter - Boulac-Curlews-Baths-Embabé-Butter-Lupin-Ancient Cairo-Joseph's granaries-Aqueduct-Nilometer-Gizah.

THE project of penetrating into Abyssinia, of visiting those immense and interesting countries in the interior of that part of the globe which is least known, to do honour to my country by an important expedition, which an Englishman, aided by every means, by every assistance with which government could supply him, had attempted successfully; in a word, to compensate by a bold and glorious enterprise, the contracted concepVOL. III. 
ions, the sordid idras, with which the ancient govern nent of France had accompanied expediti.) of that nature, as well as to add something to we means more contracted still which it employed for the execution of them; this project, I say, never quitled my imagination, and I attempted every method which could ensure me a favourable issue. Having at my disposal but a very moderate sum, and what would have been scarcely sufficient to accomplish a journey through some of the cantons of Europe, I had adopted the same plan which was my resource in the other expeditions intrusted to me, and which I would not abandon : this was to add something from $m y$ private property to what was allowed to me by parsimony, at that time the usual companion of useful enterprises, whilst excess of liberality and profusion spread a fatal lustre over the fintasies of luxury, or the attempts of a dclusive glory, and frequently of inmorality.

I can take all those to witness, who like myself were sent abroad: not one of them but has had causc of complaint, and has suffered from that spirit of avarice which directed their mission; there is not one who has not become the victim of his zeal; there is not one of them who did not receive promises of encouragement before his departure, and who was not left unsupported in 
the course of his travels; in a word, there is not one among them who, after having been the dupe of deceitful promises, after having endured the anxicties of penury, the horrors of dereliction in the midst of painful and glorious enterprises, who did not experience on his return the humiliation of soliciting in vain the slightest indemnification, frequently even the reimbursement of what he had advanced, and of presenting himself ineffectually before an insolent clerk of uffice, who treated him with haughtiness and disdain.

And this kind of contempt, which was affected with respect to great and generous undertakings, ranked among the vices with which the atmosphere of the court was poisoned. Self-love, which transforms the statesman into the wretched slave of his passions; intrigue, which, sometimes supported by ambitious opulence, sometimes conducted with grace by the most seducing as well as the most unbridled depravation of manners, had rendered it a residence inaccessible to the man whose soul, ele. vated and ennobled with the love of his country, disdained to abase himself to those shamefil resources of corruption, and to tarnish the dignity of his scntiments and the lustre of commendable actions by vile expedients, although they were the most direct means of procuring him juslice. Accordingly, that man was sure to be discouraged 
who only possessed the merit of having been usefil. He was made to drink deep of the bitter cup of neglect, and it was apparent that endeavours were made to excite regret in him, and to give him cause to repent of the labours he had endured. He who had claims upon the national gratitude, was disregarded by a government, which had long before renounced the privilege of being its interpreter; and just rewards were of such difficult attainment, their sordid parsimony contrasted in a manuer so mortifying with that profusion with which favour remunerated the cohort of its adorers, that with the smallest degree of honest pride a man chose rather to renounce his claim, than to make it good by solicitations too frequently ineffectual, and always degrading.

This was the course which I constantly pursued. Proud of having, in the prosecution of my lisbours, no other motive to excite me but the love of my country, I have with perfect disinterestedness pursued a career in which I might probably have had some success, had I been better seconded, had they understood how to turn my dispositions to a good account, and to make a more advantageous use of a zeal which obstacles inflamed instead of damping. Never have I been seen harassing a man in power with my inportunities, or basely paying my court to subalterns; and if a 
just indemnification did not follow the simple exposition of my rights, I retired, and spoke no more on the subject. Better satisfied with a generous devotedness to the public service, than with a recompense which would have detracted from its merit, I congratulated myself on this, that, if I had not rendered myself useful, I had at least endeavoured to do so, and that no view whatever of personal interest had tarnished my efforts. My conscience permitted me to taste, at the expense of my purse, a pure joy, a contentment, which the self-interested mind can never enjoy. But this character of pride and independence at which fortune is intimidated, procured for me at least some consequence, and I have often received praises in exchange for my money.

I endeavoured then, at my own private expense, to open a passage to myself for visiting Abyssinia. That of the Red Sea appeared to me the least diffi-

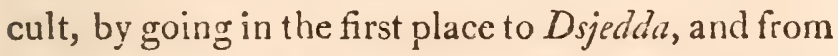
thence to Sounquem, and to Arkiko. I requested a French merchant to conduct me into the territories of the Cophts, who carry on the commerce of India by way of Suez, and who were the owners of those mi-erable vessels, by which men and mcrchandise are transported, through many delays and dangers, across those rocks and sands with which the coasts of Arabia are surrounded, and of which 
ships of this kind uever lose sight. But it was necessary to wait a long time for a passage to Dsjedda. I should have been, most probably, detaiucd there still longer, before I could have found an opportunity of reaching the shores of Ethiopia. These reflections determined me to take the route of Upper Egypt, though it was not perfectly free. A party of Mamelucs, attached to Isinaël Bey, whom Mourat had just put to flight, had retired thither, and deranged the organization, very faulty without doubt, but sometimes a protection of the government of these countries. Besides, the disturbances, although in themselves very trifling, had there opened a door for the pillages of the Arabs and the piracies of the fellahs; and the dangers, always indeed existing even in the moments of tranquillity, became inevitable, when the agitation, rarely interrupted, tormented them with concussion upon concussion.

But these circumstances did not alter my resolution; and if the desire of visiting a country unknown to me had not determined me to surmount difficulties, the uneasiness I experienced at Cairo, would have been sufficient to decide my conduct. I was eager to quit a city, where the traveller was shut up in a narrow enclosure, the linits of which he could not transgress without exposing himself, and without the danger of exposing 
posing other men, and where the quality of European was a stamp of infiny, and a itle which ensured insult and rexation.

I obtained from Mourat Bey orders addressec? to all the commanders of Upper Egypt, that they should give ine assistance and protection. To these he added a letter to Ismain Abou Ali, a very powerful prince of the Arabs, the same man by whose assistance Mourat was restored to the situation of Scheick el Belled; he wrote to his friend, that having heard his health was disordered, he had sent him a skilful physician, with whom he would be pleased, and whom he recommerded as a person dear to himself. I was thus transformed into a physician, nay, a physician to princes; and to this aitle was I indebted formy escape from the dangers which awaited me in Upper Egypt.

Letters were also procured for me from the superior of the missionaries for the propagation of the faith, as they are called, and who have four houses for the reception of monks in Upper Egypt. It will be seen what effect this recunmendation produced upon these monks, equally contemptible with those of the descrt of Nitria.

A French physician arrived from Aleppo, at Cairo, with the intention of going into India by B 4 the 
the Red Sea, was detained by I know not what obstacles, in the last of these two cities. He had brought with him from Aleppo a Maronite Christian, who spoke seven languages with the utmost ease, though without understanding the principles of them. This Frenchman, who appeared to have given up his intended journcy, ceded the Syrian to me, whose fickle disposition had inspired him with a desire to follow me. I imagined that this acquisition would be of great service to me, but I found in him a villain equally brutal and dangerous.

It is truly wonderful with what facility the eastern nations, the Turks and Arabians excepted, whose superstitious pride will not allow them to learn any other language but that of the Alcoran, acquire the power of speaking the different idioms, even those of the nations of Europe. I, who never possessed great aptness in the study of language, have often envied this natural talent of the Orientalists, and the ease with which they acquire the use of it in a very short space of time. It was not uncommon to meet among them sevcral who had the same knowledge in this respect as the Syrian, whom I had just made my unterpreter, and who spoke French extreniely well, as be did, although he learnt it merely by frequenting the company of the small number of our merchants at Aleppo. 
I had made a bargain with the reis (master) of a little kanja, to convey me into Upper Egypt. The boat was to be entirely at my disposal; no other person had the power of entering it, and I was at liberty to proceed or to stop, at my own discretion. On these conditions I agreed to pay the reis and his boat's company, at the rate of a pataca and three quarters, that is, about seven shillings and sixpence a day.

That of our departure was fixed upon. But on arriving at Boulac, we found it impossible to attempt sailing up the Nile. The wind blew with so much violence from the south, that no effort could have steered a boat against its impetuosity. 'Too well pleased with having quitted my gloomy and disquieting situation at Cairo, I was not tempted to return thither to wait for more favourable weather, and I preferred passing the day at Boulac. The better to disguise my European appearance, I had thrown aside the sesta at la Druese, and had adorned my head with a red turban, by means of which, with the other parts of my dress, I passed for a Turk, and I was at liberty to go where I pleased without exciting any obscrvation. This precaution had been suggested to me by Mourat Bcy himself: "Disguise thyself " carefully," said he to me before my departure; " equip thyself in such a manner that the most 
" clear-sighted may not be able to recognise in " thee a Nazarean. Thou maycst be such before " my Kiaschefs, before all those who possess autho" rity, and are in duty bound to protect thee: but " to those dogs of fellalis appear to be a Mussul" man; make thyself pass, upon occasion, for one " of my officers; this is the sole means of escap" ing their wickedness and barbarity."

I remained the whole day with my pipe in my hand walking along the banks of the Nile. A great stirring therc attracted attention. A multitude of men, occupied in removing bales of merchandise, exhibited the activity of commercial poris. A great number of boats arranged in rows, sunk by degrees in the water as they received their lading; whilst others whose cargo was unloaded rose above the rest. All agitated by the waves which an impetnous wind put in motion, balanced their long sail-yards, and the moving and diversified picture which the port of Boulac presented to my view, made those moments pass rapidly aw ay which I was under the necessity of passing there.

Notwithstanding the tumult which reigned upon the banks of the river, a flight of wild ducks, and which were, however, not entirely of that description, swum peaceably on a part of the surface of the water, which remained undisturbed by the winds. 
winds. I saw also two curlew's of a deep green plumage, with reflexes of a copper colour. I presume this is the species of which Buffon has takcn notice, under the denomination of the green curlew, or curlew of Italy*. These birds, which have on the whole a pretty strong resemblance to the curlew of the woods of Guiana $\eta^{2}$, are passage birds in Egypt, where they follow the course of the Nile up to the cataract. The Arabs call them schéleck.

At night I visited the baths, which at Boulac are very fine. I had at Cairo accustomed myself to the use of those kind of baths, and I was fond of frequenting them. There was one there near the quarter where the French resided, and I seldom allowed many days to pass without going thither. It is well known that these baths of the East, described by all travellers, and which I have seen badly imitated at Paris, are immense buildings, where people bathe without water, and where warm and humid vapours moisten the body, and, mingling with the sweat which they excite, descend in large drops over all the limbs. You extend yourself upon marble, heated, and slippery with humidity; a servant whose hand is enclosed in a little square

* Hist. Nat. des Ois. \& pl. enlum. No. 119.

+ Buffon, Hist. Nat. des Ois. \& pl. enlum. No. 820. Ar. quate viridis silvatica. Lin. Flamand de bois. Barrére, Franc. Equinox. page $12 \%$, tt Ornitholog. page it. 
bag of coarse camlet, rubs you pretty roughhly; he loosens and rolls over the skin, the little nasses impregnated with sweat. He gives you notice, by slight strokes with the palm of his hand, to turn on one side, on the other, on the back, on the belly. He presses, he seems to knead softly all the parts of the body, he gives a brisk movement to the members one after the other, and makes all the joints, and even the muscles of the breast, to crack. After he has cleaned you well, and suppled all your limbs, the same man conducts you towards a bason in which warm water flows: after having covered you with a thick layer of soap, he throws the water over you in large quantities, which, in falling along the body, carries off the froth of the soap. Of all the processes of these baths, this was the one which incommoded me the most. The quantity of water thrown over iny person deprived me of breath almost even to suffocation; I was almost always reduced to cry for mercy from my pitiless waterpourer. You are afterwards re-conducted into the first room where you had left your clothes, and there laid down and wrapt up in dry linen, which is changed as it imbibes the humidity of the body; young boys gently press all the parts of it, in order to dry them perfectly and by degrees. They likewise draw a piece of pumice-stone over the soles of the feet. During these operations, which it is impossible to perform with greater delicacy, you enjoy 
juy a delicious repose, and cannot forbear yielding to a kind of voluptuous languor.

The little bag or rubber of the eastern nations has succeeded to the curry-comb of the ancients, and is far preferable to it. Being formed of stuff, it is far more soft, and draws from the pores all those humours which obstruct them, much better than the instrument of metal with which it was customary to scrape the skin among the Romans. But although the baths in Turkey, and particularly those of Cairo, are extremely handsome buildings, they are far inferior in grandeur and magnificence to those which the Romans constructed under their emperors. The ruins of them which remain, strike us with wonder. Vitruvius has given the description of these supcrb buildings. They were of so prodigious an extent, that Ammianus Marcellinus compared them to provinces *. All the most brilliant productions of luxury, all the voluptuousness which was the offspring of effeminacy, were assembled there. You could there enjoy at once all those pleasing sensations which the air and the water produce; moveable bathing-machines were suspended, and to the pleasure of bathing was added that of being gently swung in the air.

More simple, and perhaps more agrecable, the baths of Turkey and of Egypt have many atirac* Potzìs provinciarum instar quàm ullius ediffiii formá. 
tions for all the inhabitants of the East. 'They had very great allurements in my eyes also, and indeed there was nothing at Cairo I liked but them. The most perfect tranquillity, the most rigid decency, reigued through the whole enclosure. Although several persons were assembled there, not a word was spoken in the room, around which the beds for repose were arranged, and where you take off and put on your clothes. Every one in calmness, in silence, and in voluptuous enjoyment, experienced those sweet and truly undefinable scnsations which delicate pressures could produce.

The women have their appointed days and hours for visiting the baths. At that period no man dare approach them. Other women appointed to wait on the bathers, cause them to pass successively through all the ceremonies observed in those kind of places, but they are performed with more care and delicacy than among the men. Rose-water is not spared, and the smoke of perfumes mingles itself with humid rapours. As the women have not, like the men, renounced one of the most beautiful ornaments of nature, the care of their head-dress is one of those most attended to in the toilet of the batlıs. To cleanse their hair, they make use of a kind of clay which is brought express from Turkey, and which they bedew with sweet-scented waters. But it is not solely a motive of health, or the desire of cleanliness, which tempts them to risit the baths: 
they form there parties of pleasure. Peaceful calm ceases to reign amongst them; young and beautiful captives there abandon themselves to mirth, and to those amiable follies which, if we must believe a certain critic, are not always perfectly inmocent.

Opposite to Boulac, on the western shore of the Nile, is the little village of Embabé, renowned for the excellent quality of the butter made there. This is the only place in Egypt where butter may be caten fresh; in every other part it is good for nothing.

The fertile plains which surround Embabé on the westcrn side, enrich it with several kinds of culture. They produce, in particular, a kind, or rather a variety, of lupins*, of which there is a great consumption in Egypt. They boil the peas with salt and water, and eat them after having taken off the hard and thick skin with which they are covered. They are sold ready dressed in the streets and in the markets. The village of Embabé supplies Lower Egypt with them, where they are known under the name of embaben, after the place from which they comc. However, the general name of these lupins is termess. They will neither serve for soup, nor for any other sort of ragout, they are so

* Lupinus termis; calycibus alternis, appendiculatis, labio ufroque integro, acuto. Forskal, Flora Egypt.-Arab. page 131 .

extremely 
extremcly hard; but when boiled with salt, they are very much to the taste of the Egyptians. You hardly sce any one in the strects but pcople cleaning termess. The Christians of the East, little ambitious of imitating their tyrants in an abstinence from strong liquors, eat lupins, to excite in them a desire to drink brandy, which they often do to excess. They make also a flour from it, which they use in the same manner as that of farinaceous plants. It is, in particular, very good for clcaning the hands and softening the skin. The stalks of the lupin reluced to cinders, serve in preference to other coals in the preparation of gunpowder: thus this plant combines in its parts several kinds of utility.

The south wind having subsided, we departed from Boulac the 21st of March 1778, at eight o'clock in the morning. Our voyage was not of long duration. The eis having pretended that some repairs were necessary to the boat, we stopt at Old Cairo, the Mins el Atik of the A rabs, about half a league from Boulac. This city, which marks the situation of the Babylon of Egypt, is the port of those boats which descend from Said, as Boulac is that of the Delta. In the middle of the Mahometan mosques, the Jews liave a synagogue, and the Catholics a convent and a church; but the Cophts, as being on thcir own territories, have re- 
served to themselves that which passes in the eyes of the religious for the most precious spot; this is a grotto or low chapel, in which, as a pious tradition informs us, the Virgin lived some time with the infant Jesus when they were obliged to flee into Egypt. Such traditions as these are never without their use to the monks. When the Latins wish to visit this chapel, they pay for their admission to the Cophts; and if devotion carries them so far as to celebrate mass there, the Cophtish monks are paid for this complaisance by those of the Catholic persuasion; and these take care in their turn to receive a recompense from those who employ them.

You see at ancient Cairo the granarics of Joseph, if the name of granaries can with propriety be given to a vast space of ground surrounded with walls twenty feet in hcight, and divided into a sort of courts which have no roof, or any other covering whatever, in which are deposited the grains brought out of Upper Egypt for the revenue, where they are the food of a multitude of birds, and the receptacle of their ordure. The walls of this enclosure are of a bad construction, they have nothing in their appearance which announces an ancient building, and the love of the marvellous alone could have attributed its elevation to the Patriarch Joseph.

VOL. III.

c

Another 
Another work of the Arabs, which is, nowever, remarkable for its beautiful construction and its boldness, indeed the only one worth seeing in the aucient city of Cairo, is the aqueduct which conveys the water of the Nile into the castle. It is supported by three hundred and fifty arcades narrow and very high. The water is conveyed thither by a chain-pump with four wheels, which is moved by oxen.

In front of ancient Cairo, the Nile lcaves in the middle of its bed an island about five hundred paces broad, on which is built the mekkias, that is to say, measure. It is there, in fact, that on the graduations of a pillar the increasc of the water is measured, and after these observations, public criers go about the streets of Cairo proclaiming the successive heights of the water, the promisc of fertility and abundance. It is thought that this nilometer was built by the Arabs. The island is called Roudda, or gardens, because, in fact, it is laid out in gardens, and inhabited only by gardeners.

On the opposite side of the isle Roudda, the lown of Gizah extends itself on the western shore of the Nile. The numerous date-trees which surround it, among which the lofty iurrets of its mosques mingle themselves, the river, whose 
waves roll by the very foot of the houses, give it from afar a pleasing appearance. The French merchants at Cairo had a country-house there, on the very brink of the Nile, and to this they frequently resorted for the purpose of breathing a pure air, instead of those infectious exhalations among which they habitually lived, and to enjoy a respite from that turbulent existence which disturbed their minds in the city. Gialh brings back the recollection of mighty objects. Memphis was in its vicinity, and it is still the nearest place to the most valuable monuments which ancient Egypt has left of her glory and her power. The pyramids are at the distance of about two or three leagues from it, and they bcar indiscriminately the name of the Pyramids of Memphis, or the Prramids of Gizah. 


\section{CHAP. XXXIX.}

Departure from ancient Cairo-Scheick ItmannQuarres-Monasteries-Fishes and Birds-_Whirlwinds and water-spouls-Watering of the ground-Particulars of the voyage-Houses of the villages of Upper Egypt-Carthamus-Sudden gust of roind from the south-Benisouef-Accident on the voyag-Muntuins-Manner in which the women of Upper Esypt carry water.

IT was not without considerable trouble that I collccted my reis and his sailors, who were busy conversing with their acquaintances, and never thinking about the repairs necessary to the boat. I had still more difficulty to make them resolve on departing. We quitted ancient Cairo on the evening of the same day that we arrived there. A fresh brceze from the north had succeeded to the scorching and contrary wind of the south. Tivo immense sails disposed in hares-ears $*$ drove on our light kanja with great rapidity; and her prow, whitened by the foam of the waves, opened for itself an easy passage, notwithstanding the resistance of the cur-

* This is the name given to the arrangement of two triangular sails, when the one is stretched to the starboard side, and the other to the larboard.

rent. 
rent. We stopped towards night, about cight leagues distance from ancient Cairo, opposite to Scheick Itmann, a little village of which the houses or huts are of mud. Its appearance is not the less pleasing. Groves of date-trees surround it; their verdant summits, which bear long and shooting stalks, whilst others are bent downwards by the winds, seem to cross each other in order to form a shade to the roofs of the houscs, enliven the gray and obscure tints of the village, render it beautifully picturesque, and form a most interesting landscape. Several white herons came to pass the night upon these date-trees, and composed there a charming bouquet of a beautiful green and a dazzling white.

From ancient Cairo the castern shore of the Nile is bordered by that chain of mountains which begin at Cairo itself. You see in them great cavities formed by the extraction of the stones which have becn quarried there. The opposite side of that mountain which overlooks the Nile, has beendug up over almost all its surface. It is probable, that from thence, in ancient times, those stones were extracted which they employed in the construction of the city of Memphis, and of the pyramids. The masses of which these last monuments have been built, arc absolutely of the same grain with the calcareous rock of the mountain : and this circum. 
stance would have been sufficient to overthrow the opinion of some of the moderns, who imagined that these pyramids were only composed of factitious stones, though besides the most ancient of the historians who have written on Egypt, Herodotus, had not positively said, that upon the mountains of Arabia (that chain which is on the side of the Red Sea) may be seen the quarries from whence were hewn the pyramids of Memphis:.

At a full quarter of a league before your arrival at Scheick Itmann, on the eastern shore of the river, is Toura, which has retained something of the ancient name Troja, which it formerly bore. Or each side, and from distance to distance, you see those useless buildings, which, under the name of monasteries, cnclose societies of men more uscless still. They were peopled by Cophtish monks.

Opposite to Scheick Itmam, a village called $M a-$ sara (a press) appears on the same side with Toura; but retreating somewhat farther into the land. Above the first mentioned place there is a pretty large canal, the direction of which to the westward does not extend very far.

I bought some littlc bemis, fishes which I have made mention of at the conclusion of the preced-

* Book II. sect. 8. Iarcher's translation, vol. ij. p. 7. 
ing volume. A fisherman caught them with a siveep-net, which he threw from above the brink of the river. He did not catch any others; but if the fishy brood was rare in the waters of Scheick Itmann, numerous flocks of birds animated its vicinity. The lively and active lanndress rambled through the fields, waving its long tail; the ignoble kite, the same bird which at Cairo is a denizen of the place, interrupted with his shrill and plaintive cry the amorous cooings of the turtle-doves, perched upon the date-trees, while the sivallows, on pointed wings, cleaved the air in their rapid flight.

On the $22 \mathrm{~d}$, towards mid-day, we continued to proceed up the Nile. I very soon discovered, at a little distance inland, the pyramids of Sakkara, and likewise the town of that name, celebrated for the mummics of men and of animals, which are preserved in its vast catacombs. We passed opposite to Schim, a village situated at some distance from the western shore. A little higher up we saw, on the other side, a place callcd Berdrisgé, and we stopped about six o'clock in the evening bcfore $K a f r$ läut, a village of earthen huts, like those which I have just mentioned, and the residence of a Kiaschef. The western shore of the Nile is in this place lofty and cteep, and the village built on it may be perceived at a distance. 
We had procecded nearly seven leagues in the course of this day; the north wind continued to be favourable to us; but it blew sometimes violent squalls, and in whirlwinds which, but for the precautions I was carcfui should be observed, and which would have given no uneasiness to the Egyptian mariners, might have rendered it dangerous. These whirlwinds are very frequent upon the Nile; they communicate their motion to that part of the river on which they bear, and cause it to boil up. I had the pleasure of secing, in the plain of Sakkara, columns of sand, raised by the wind almost to the clouds, and preserving in their immense height the perpendicularity of a perfect cylinder.

That chain of mountains which, at the back of Toura, was close to the banks of the Nile, retires here, and leaves a vast space for cultivation. There are no longer here the level plains of the Delta, and the other cultivated parts of Lower Egypt, which by easy waterings are moistened sufficiently to produce fertility. The waters of the river flowed in their natural bed, between two steep shores. In order to water their lands, the inhabitants are obliged to employ machines for drawing up the water. These are a kind of swipelevers, placed upon a horizontal cross.bar, and to which leathern buckets are fastened. A man, half covered 
covered with rags, and animating himself with singing mournful and rustic songs, passes whole days in moving one of these levers, and in pouring the water into troughs or furrows, which convey it to the plantations. Very often, four or five of these machines are necessary, among which there are some double, that is, the same cross-bar supports two levers, in order to raise the water to the level of the ground to be watered. The eastern shore is elevated and perpendicular; the western has an imperceptible declivity; but it requires still greater labours, on account of the necessary length of the water-conduits, in order to diffuse the water to advantage.

The clumsiness of these hydraulic inventions, the nakedness of the misery, which renders hideous those unindustrious and half-savage creatures who employ them; habitations, the walls of which, hardly raised above the ground, are built with no other materials than miud, are objects which inspire disgust and melancholy, when on looking back in imagination to former times, we compare the ancient situation of the very same country with that which disgraces it in the present day.

Two numcrous flights of wild ducks made their appearance in the course of this day; and on the shore, white herons, goëlands, and wild gecse, 
were narrowly watching the fish on their passage.

With pcople like the Egyptians I could not expect to accomplish a voyage exempt from disputation. Greedy and dishonest, whatever benefit you confer on them, they are never contented, and the more that is given them, the more they think they have a title to exact. I had with me an ample provision of coffcc, and some excellent tobacco of Latichea; and from the moment of my departure, I had shared it with my boat's crew; but these insatiable rascals insisted that I did not give them enough; and as if my liberality had been a debt due to them, they demanded that I should deliver up to their discretion the coffee and the tobacco. However, to let them sce that their claims, uttered in the most insolent tone of voice, did not produce any impression on me, and how much they deceived themselves in believing they could intimidate me, I discontinued the donation of those little douceurs, which I had the complaisance till then to bestow. They broke forth into menaces and murmurs, which were of pretty long duration, but which they gave up, when they perceived that they derived no advantage whatever from them.

At eight in the morning of the 27 th, we departed 
parted from Kafr läat with a light north wind, which, about mid-day, arose into very violent squalls. After a navigation of about the space of five leagues, we stopped at Ritha, a village on the western shore, and almost opposite to which is $A:$ fieh, situated at the foot of the mountain of the east, upon a narrow canal, formed by a pretty considerable island. Boats do not pass by this canal, unless they are to land at Atfieh itself. This was formerly a city consecrated to Venus, under the name of Aphroditopolis.

I saw a very remarkable pyramid in-land, at four or five leagues distance from Riha. The course of the river is divided from Kafr Iäat by a chain of small islands, among which there are some pretty extensive, and which advance sometimes toward the one shore, and sometimes toward the other.

A multitude of birds, of different kinds, are to be found in the environs of Riha. There are herons, armed plovers, others of a sort which I have described in the Delta, at Mehallet-Abou-Ali, in the preceding volume, a great many lapwings looking for worms on the brink of the river, \&c.

The squall of wind fell in the evening; a total calm in the atmosphere succeeded it, and continued till the morning of the following day, the 
24 th. Not the slightest breeze swelled our sails to forward our voyage. The sailors drew the kanja along by a rope; a light wind from the north-east arose in the morning, but it was not of long duration, and we stopped at Zoule, a cousiderable village ou the western shore, at the distance of about two leagues from Rika. In the afternoon the wind came round to the west, and afterwards to the south-west; of consequence it came from the same point towards which we were directing our course. I made them to take the rope again, and we arrived by slow degrees at Zavoui el Mansloub (the watering-place of the cross), a little town built on the western shorc of the Nile, opposite to Géziret Barraké (blest island), a little isle, on which you see a village, and lands in a state of cultivation*. We had only procecded one lague beyond Zoule. These denominations of cross of benediction, collected on the same spot, are very remarkable in a country where crosses and their benedictions are looked on with horror.

At night, one of my companions caught with a fishing-line a small ccl of the Nile; the upper part of its body was of a lightish green, without doubt because it was young.

* Mr. Bruce has very improperly reproached Nurden witls having written that Géziret Barraké meant the watering of the cross. It is Zavoui el Nansloub to which Nurden has given that meaning. (See the Work of thofe two travellers.) 
It was equally impossible, on the 24 th, to makc use of sails, and we were obliged to continue the tedious and fatiguing method of working the boat with a rope. I walked along the side of the Nile, and killed several wild pigeons, whose hard and dry fiesh had nothing in it to gratify the appetite. I saiv also several armed plovers, and of those which have been mentioned formerly.

Our sailors rested themselves, at the end of a league, at Konrigé, a town to the westward of the river. There are here several mosques, the indication of an extensive population. We took our departure again, in the afternoon, with the wind still against us, and we moored for the night at Schment el Arab, a village built on the same side with Komrigé. The houses in this place, like all those of Upper Egypt, are of a square form, and pigeon-houses are raised over their roofs, which have, from a distance, the appearance of ornaments of architecture: these give to the villages a pleasing look before you reach them, but, on your arrival, you perceive only mud walls, and the livery of wretchedness.

During this complete day we had not advanced quite so much as three leagues. The whole length of this space of the eastern shore of the river is one steril and uninhabited plain of sand. That of 
the western, on the contrary, presented to the view ficlds adorned with cultivation and fertility. I observed there several large tracks of ground planted with the carthamus:, which the Arabs call asfout. Its seeds, which are described sometimes by Europeans under the name of parrots'seeds, because they are the favourite food of birds of that species, are known in Egypt by the name of cartom, from whence we have derived that of carthamus. Under a shell which is hard, thick, and of a glittering white, these seeds possessing nearly the form of a quince, contain an oily almond of a sharp and bitter flavour. The Egyptians extract an oil from this fit for burning. With the husks they make a paste, of the colour of chocolate, but without having the taste of it.

But the most uscful part of the plant, and which is incleed an indispensable requisite in the dying of cloths, is the flower. Its colour is a beautiful saffron red, but it has a very strong and disagreeable smell. When dried it is transported into Europe. It is called, in the commerce of the Levant, by the name of saframun.

The culture of the carthamus is one of the most productive carried on in Egypt; it there occupies entire plains, and the safranum is exported in large

* Carthanus tinctorius. Lin. quantities, 
quantities, and is bought up by European traders. Under a genial and pure sky, the flowers acquire, in a short time, the brilliancy of that beautiful colour which distinguishes them, and no rains descend to tarnish their lustre. In our northern countries, on the contrary, the rains would be always an inconvenience opposing the culture of the carthamus; not because it would not thrive with us, for, during several years past, I have cultivated this plant in a spot in one of our coldest departments, that of Meurtha, but without reaping any advantage, at least from the crop of flowers. In truth the slightest shower of rain is sufficient to soil or break them down, and to destroy the crop. The climate of Egypt agrees with it perfectly, and it is an important branch of commerce for the new colony.

We commenced our route again on the $26 \mathrm{th}_{\text {s }}$ and were still reduced to the necessity of hauling our boat along, the wind continuing to blow from the south. It employed us the whole morning to reach Bousch, a town about a quarter of a league upon the western shore, in which was held, at the very time of our passing by it, a considerable mar. ket for cattle and provisions.

We encountered, at Bousch, one of those violent gusts of wind from the south, so celebrated in those countries, and at the same time so dangerous. 
Wretched is the situation of those who find themselves entangled in the vast sandy deserts with which Egypt is bordered; intrepidity is then of no avail whatever, and the most valiant armies may be there overwhelmed with clouds of sand which the wind drives impetuously along, may be stifled to dcath, and perish in despair. The atmosphere was on fire, and at the same time darkened by whirlwinds of dust. The thermoneter of Réaumur rose to twenty-seven degrees. "Both men and animals inhaled only scorching vapours mingled with a fine and hot sand. The plants were dried up; all animated nature faded away.

This gust of wind still continued on the 27 th ; it seemed even to have augmented in violence. My boatmen were quite dejected; it was by dint of promises alone, that I could prevail on them to put the kanja in motion once more, still dragging it with the rope; but the impetuosity of the wind very soon rendered their efforts useless, and we were obliged to stop behind a point of sand, which put our boat under shelter from the current, which the fury of the gale increased in rapidity and argitation, but which did not sccure us from the inconveniencies we sufiered from the south wind. The heat was even greater than on the preceding day. The thermometer had risen to twenty-eight degrecs. The sweat distilled from every pore, and the 
the sand which the wind hurried along with it adhered to nur faces and formed a mask on them. Our employment cvery moment was to kcep our eyes cool with the water of the river, to cleansethem from the sand which stuck to them, and to keep them open. The air was darkened with a thick fog of sinall dust, and as red as fire. It insinuated itself into every thing. Our caffas, our closest shut trunks, were not secured from it; and if we attempled to eat, our mouths were filled as much with dust as with food. $x$

This scorching wind abated at length, towards the evening, and we were enabled to approach near a little town called Benisouef, built to the westward of the Nile, and about four leagues from Schment el Arab. The houses, constructed of brick cemented with earth, and the turrets which seemed to vie in height with the datc-trees surrounding them, render the appearance of this place less harsh, less gloomy than that of the other villages which I had hitherto seen. Of all the places situated along the Nile from Cairo, that is, for the space of more than thirty leagues, this is the largest, as it is the least wretched. A manufactory of coarse carpets renders it commercial. The country around it is fertile and smiling, and the people who cultivate it seem to be less miserable, less depressed by suffering, than those who live nearer to the capital. A 
Kicuschef commanded at Benisonef. As I dich not choose to make any stay there, I dispensed with the ceremony of visiting him.

A dead calm had succecded, on the $28 \mathrm{th}$, to the burning tempest from the south. Only, towards four in the evening, a slight brecze from the north arosc; we took the advantage of it to continue our route, and we arrived in the night-time at Bébé, a larese village, the residence of a Kiusclief, and situated on the same side with Benisouef, from whence it is distant only about three leagues. You see here a mosque, and a convent of Cophts.

In this voyagc by night, we run the greatest danger imaginable, through the negligence and unskilfulness of our boat-men. We ran foul, in the most rapid current, of one of those large barges which are called masch, and which come down from Upper Egapt very heavily laden. I know not how our frail kanja sustained such a shock, without being dashed to pieces. This was not all; and as if we had been destined to perish at that very instant, after having driven violently against the barge, a. gust of wind came upon us unexpectedly, which, taking our sails ahead, endangered our foundering, and half filled our little vessel. We spent the remainder of the passage, as far as Bélé, in baling out the water which the boat had taken in. 
On the morning of the $2 g^{\text {th }}$ we set sail with a fine brceze from the north-east. The weather was delightful, and the atmosphere, freed from the clouds of dust with which it had been loaded the preceding days, was encircled by its resplendent canopy of azure. Mountains of sand and of rock elevated and hewn perpendicularly, present on the eastern shore of the Nile, the course of which they contracted, a chain of impreguable ramparts. They extend themselves to a distance by immense and frequent interscctions into the desert, the horrors of which they augment; and the river, washing them with its current, imperceptibly undermines their foundation. These lofty masses of stone advance sometimes into the Nile, so as to render the straits which they thereby form very dangerous for navigation. In other places they resemble natural fortresscs, which would be, in rea lity, abundantly sufficient to defend the passage of the Nile. Refusing to harbour any human being, these barren and horrible mountains are the domain of a multitude of birds who have there fixed their habitation, where they never meet with any disturbance, and from whence they spread themselves over the waters, and through the country, to search for prey and for pasture. The name of Dsjeblel el Teir (mountain of the birds) given to this chain of rocks, indicates with what sort of inhabitants it is peopled. 
We anchorcd at night at Scheick Zäar, after having sailed nearly five leagues. This is a pretty large place on the western shore. We departed from thence on the $30 t h$, and arrived at night at another well-built town on the same side, and which is called Senn-Seni. The north wind was very high, aud the atmosphere gloomy and loaded with rapours. An innumurable flight of wild ducks passed near us in the course of this day.

I observed, at Senm-Seni, the manner in whicls the women there carry their provision of water from the Nile. It is impossible for them to be more heavily laden; they carry three earthen vessels; one, very large, upon the head; the second, somewhat less, and supportcd by a rope which they pass along the forchead, hangs behind the back; and, to conclude, the third, which is least of all, is placed upon the left shoulder and held by the right hand.

The weather cleared up on the $3^{1 \text { st, }}$ and a fine breeze from the north soon carried us to Miniet. The same chain of mountains of which I have been speaking, followed that shore of the Nile which looks towards Arabia. Cut perpendicularly, it appeared like a lofty wall constructed by the hand of art. 


\section{CHAP. XL.}

Minie-Bardacks-Ancient city-Manner of setring fractured limbs-Rain and squalls of avindScheick Abadé-Ancient city of Anlinoë-Catacombs - Mellavoui - Mountain of AloufedaManfelout-Convent of the Pulley-Large boat -Siont-Jackal-Grotloes of the MountainsBirds of Siout.

If the eastern shore of the Nile presents, in this part of Upper Egypt, a frightful appcarance, by its sands and barren rocks, that of the western attracts attention by its cultivated fields and its numerous habitations. Among these Miniet descrves to be distinguished. This city is very pretty when compared with the other places of the same country. Narrow streets through which you walk in the dust, houses built of unburnt bricks and bound with earth, slovenly and irregular buildings, are not, surely, very fine ornamcntal features in a city. However, when for a long time the eye had habitually dwelt only on towns and villages, the condition of which excited pity, the city of Miniet could not fail to give pleasure. The house accupied by the Kiaschef, as well as those of some of the great people, was built of stones, and their whiteness 
lieved the monotony of the reddish gray of the others. The bazars, or places for the resort of merchants, are very "cll arranged; the cruivds which frequent them announce ai extersise population, and some activity in conmerce. 'The cxchequer thas established there, for loaded veusels. a tax, which is the more easily levied, as the Nile is not very broad in this part. There is lere a manufactory of earihen vessels called bardacks, in which the water acquires that coolness so nccessary in a scorching climate where you have frequently occasion to quench your thirst. The clay of which they are formed is dug from the environs, and they are a very profitable branch of industry to Miniet.

Pillars of granite broken and overthrown, others shanding, and heaps of rubbish, indicate that Miniet occupics the place of a more ancient city, but there is a diversity of opinion respecting its name. Some have pretended that this was the sitc of Fiermopolis, doubtless Hermopolis the Great, a cclebaited city distinguished thus from two others of the same name formerly cxisting in Egypt. Others are of opinion that these ruins are those of Cynopolis where the dog was worshipped; finally, Mr. Bruce looks on Miniet as the ancient Philae. However this may be, the modern city is nearly fifty leagues distant from that of Cairo. 
Two letters of recommendation had been given me at Cairo, the one for the Kiaschef of Miniet, who was called Attas, and the other for a rich proprietor, a friend of the French merchants, who then resided on his own estates. They were both absent. The Kiaschef was making the tour of his district to levy contributions, and the Turk of Cairo was in one of his villagres not far from Miniet. I had the letter intrusted to my care conveyed to him. The next morning he sent me his complinents, with a present of five sheep, and two large pots of butter, which he begged me to accept as a slight indemnification to compensate the hospitality which he lamented he was not on the spot to exercise towards me.

The second in command at Miniet having heard it said that I was, or that I ought to be a physician, clesired me to be called in. He had broken his leg three days before. A Copht had set it again, but he had treated his patient in a truly curious manner. He was laid on the earth, without either mattrass, mat, or carpet, but on a bed of sand. His thigh and leg were stretched out and fastened between stakcs driven into the earth, which supported likewise a little brick wall crected, on each side, so that a piece of mason work contained the fractured limb, till the cure was perfectly completed. In order to hasten the knitting of the bone, the sur-

D 4

geon 
geon had composed a kind of plaster, with earth, oil, and the white of an egg, and this he spread over the limb every day.

On the evcning of the 2d of April a dreadful storm arose. A shower of hail, which is a very uncommon thing in Upper Egypt, was accompanied with sudden and violent gusts from the soutli-west. Whirlwinds of clust intercepted the rays of the sun, and short and precipitate undulations agitated the surface of the Nile. This stormy weather having subsided on the afternoon of the $3 \mathrm{~d}$, we departed from Miniet, and stopped three leagues farther off at Moulaha, a village belonging to the Kiascheflick of Miniet, and built on the same shore with that city. The wind came round at night with great impetuosity to the north; we were very much incommoded the whole night through by the motion of our boat, and the continual shocks she underivent against the shore.

The same gusts of north wind continued to pursue us still on the $4^{\text {th }}$, and carried us with a dangerous velocity to Scheick Abadé, a resort of pirates, to the east of the Nile. Immense ruins, and a long succession of rubbish, announce that a great city existed there in ancient times. This was the fruit of a disgraceful passion, which poorly disguised the appearance of gratitude affected by 
Adrian in founding it. It is well known to what a degree this prince, renowned for his political and warlike talents, was, at the same time, despicable, on account of his passion for Antinnis, the perfection of whose form is evinced by one of the most beautiful statues of antiquity, still in preservation. Adrian, during the time that be was in Egypt with his court and army, consulted the soothsayers, whose responsestruck hisimagination. The oracle declared that the greatest danger threatened him, unless a person dear to him, and by whom likewise he was beloved, shonld sacrifice himself for his preservation; and the dastardly Emperor had the cruelty to accept of the sacrifice. The beautiful and generous Antinoüs precipitated himself from the summit of a rock into the Nile; and the vile despot thought to efface his disgrace and his ingratitude, by building, in honour of his favourite, whom he looked upon also as his deliverer, a city which, under the name of Antinoë, perpetuated his barbarous credulity and his criminal affection. He embellished it with all that art can imagine the most precious. The statues of Antinoüs were there considered as sacred representations; he built temples for him; he instivuted games and sacrifices, and he himself regulated the worship by which he was to be venerated. 
Antinoe had filled the place of the ancient Egyptian city of Abiclus, in which a divinity who bore the name of Besa was worshipped. This god delivered oracles, and his celcbrity lung supported itself. The ancicnt city of Abidus, and that of An. tinoë, are now equally ruinous. What remains of this last excites regret for its destruction. You behold not in these ruins the unwieldy and gigantic monuments, those cnormous masses of stonc, which the Egyptians raised rather to astonish than to charm the eye. Every thing there was in just proportion, all possessed those delicate contours, and those elegant forms of the beautiful architec. ture of the Greeks and of the Romans.

My reis made many difficulties about approaching the sliote which covers the ruins of Antinoë. It is peopled by the worst tribe of Egyptians, and the mosi determined robbers. They attacked Mr. Bruce, when, on crossing the Sazil, he intended to stop at this place*. I observed all the precautions which prudence suggested, and I landed with my draughisman. The extensive site, strewed with the most beautiful fragments, overwhelmed me with astonishment and admiration. It must have occupied a considerable tirne to travel over them' all. The night approached, and it was impossible either

* Travels to the Sources of the Nile. 
to pass it on that dangerous coast, or to stray very far from the boat.

The ferocious men, who dwell around the ruins of the rity of Adrian, employ themselves in pulling down those parts of the edifices which stull remained, and in glutting their savage disposition by the babitual commission of destruction. In the time of Vansleb*, and of Paul Lucas, there were many more pieces of architecture existing entire, than I myself beheld. The greater part of the buildings were constructed of large bricks, and their red colour was still in perfect preservation. That which appeared to me the most remarkablc, was a triumphal arch, or magnificcnt gateway, supported by fluted pillars. The front is fifty feet in length. A very bad representation of this is to be seen in the Travels of Paul Lucas $r$. The capitals of the pillars in particular are very badly represented. A more clear idea of it may be formed from plate XXVIII. It is evident that the intention was to have taken a complete delineation of this triumphal arch, which, to all appearance, scrved as the gate of the city; but while the designer was employed in this work, and I, on my part, was" examining some other portions of the ruins, the noise of a gun fired off by one of our

* Nouvelle Relation d'Egypte, page 386 et suiv.

+ Voyage fait en $3 y+$, tome ii.

companions, 
companions, who was placcd as a sentinel, gave us notice of the approach of a gang of robbers. We had only time to escape to the boat, which was inmediately pushed off shore, and we got clear, with only the menaces and bullying of those barbarians.

You observe also, on each side of the gate, holes cut for the hinges which sustained the foldingdoors. The country people say that these doors are at Cairo, and that they were transported thither by a devil. Paul Lucas saw them there covered with plates of iron, and serving to close up an arch which is near the palace of the grand provost*, without doubt the Ouali, the officer who at Cairo is intrusted with the affairs of the police. A considerable number of pillars were still standing at the other extremity of the city of Antinoë, towards the mountains. All the remainder presents nothing but a confused mass of pieces of architccture broken and overthrown.

On the opposite side of the mountain, which terminates, towarls the west, the ancient enclosure of Antinoë, you distinguish a considerable number of openings dug in the rock. These caverns were undoubtedly places of sepulture, the $c a$ tacomos. There are places such as these all over Thebais, principally in the environs of great cities,

* Nouvelle Relation d'Egypte, page 384. 
along those two chains of mountains with which - the Nile is bordered, and sometimes straitened. The inhabitants, too grossly ignorant to comprehend those means with which the arts supplied - their ancestors, ascribe these cxcavations to demons. Superstition produces similar effects upon the most opposite characters; for the missionary Vansleb appeared to agrce in opinion with the then natives of Egypt; it seemed equally impossible to him that human beings could dig such cavities; but he subjoins to his opinion this pious mollification, that the devils were forced to become such good workmen by means of exorcisms*. On the other hand, the Christian legend beholds in that immense number of grottoes in the mountains of Thebais only the solitary retreats of holy hermits, whose indolence was but poorly disguised under the mask of contemplation; a fine-sounding word, but totally devoid of meaning, when it is applied to the life led by beings of this sort.

The mosque of the village in the neighbourhood of Antinoë, and whose aspect and population form so striking a contrast with the superb buildings and the urbanity of the ancient city built by Adrian, contains the tomb and the relics of a saint who has given to this place his name of Sheick Abude. But, what is truly diverting, while the

* Nouvelle Relation d'Egypte, page 384. 
Mahometans regard this saint as a zealous parti-zan of the Alcoran, the Christians claim and venerate him as one of their bishops, who received the mouruful honours of martyrdom at Insine *. But enough has becn said respecting those absurd chimeras, of which the men of all ages and of all nations have been the may-game.

Ne quitted the shores, formerly flourishing, but now desolate, of the city of Antinoüs. We came to anchor opposite to Mellavoui, three leagues from scheick Abade. Mellaroui is a little city, of a very beautiful appearance, situated at abont half a league from the western banks of the Nile. A riaschef was resident there. The plains which surround it are very fertile, particularly in wheat. A large quantity of that grain is exported thence into Arabia.

On the $25^{\text {th }}$ of Aprit we journeycd from Mellavoui to Manfelout, where we arrived in the cvening. The distance between these two places is nearly ten lcagues. At two icagues below Manfelout the castern shore of the Nile is a chain of very high mountaine, entirely of barren rock. The waters of the river have undermined them below, by which means the upper part projects considerably beyond the lower. This chain of rocks is called the Mountain of Aloufeda, after the name

* Vansleb, Nouv. Relation d'Egyple, p. 387 . 
of a holy Mussulman who is interred there, and in honour of whom a little chapel has been erected. By the side of this monument of the piety, or rather of the silly superstition, of the Mahometans, men of the same religion, great devotees to Saint Aboufeda, but abandoned robbers, occupy cares hewn in the rock, formerly peopled, it is said, by anchoritcs, if, horvever, these excavations are not, like those of Scheick Abade, and of the two chains of mountains between which the Nile flows, in the upper part of Egypt, ancient funeral apartments aud antique tombs; for with whatever pious belief one may be inspired, it is hardly possible to believe that those myriads of grottoes there hollowed out, could have becn the work and the habitations of so many solitary drones, whose farourite passion was not, as is well known, the love of labour; with so much the more reason, that in several of them may be still found incontestable proofs which evince their high antiquity. Whaterer may be the fact, the robbers who inhabit them at present, are the most formidable of pirates for the navigation of Egypt, and the most difficult to exterminate, bccause they conceal themsclves within the inaccessible cavities of those mountains.

Besides the danger which you are in of being plundered, whilst sailing by the mountain of Aboufed, you are there likewise exposed to the risk of shipwreck. 
shipwreck. The Nile is rapid and narrow in this place, and the force of the current, or the violence of the wind, may drive the boats against the rocks, and dash them to pieces. At the time we passed, the wind was furious, and the river extremely agitated.

The city of Manfelont is very considerable, and more handsome than that of Miniet. The sireets are broader and better planned. A country which gives, in abundance, productions of every kind, renders its situation agreeable; and fruit-trees, above which numerous palm-trees shoot forth their branches, shade its walls. Its commerce consists in grain of every kind, and in cloths, which are manufactured there in great quantities. The name of Manf Elout, or Mionfallot, as Father Vansleb writes it, signifies, in Arabic, the place of Lot's exile; because, from the report of the same Jesuit, who grounds his opinion on the very suspicious tradition of the Cophts, a certain Lot was exiled thither by his brother, one of the ancient kings of Egypt*.

The Kiaschef of Manfelout was at Cairo, when I departed from it. One of our merchants, who was intimate with him, had given him information of my intended journey. The honest Mameluc in-

* Nouv. Relation d'Egypte, page 360. 
sisted on giving me a letter of recommendation to his steward, and made me promise that I would lodge in a house which he possessed at Siout. The man to whom the letter was addressed was not at Manfelout, but I met with a most cordial reception from the treasurer (kasnadar) of the Kiaschef.

Opposite to Manfelout, on the eastern shore of the Nile, is a large monastery of Cophts, completely enclosed with high walls, and into which you are hoisted up in a basket, drawn by means of a pulley. This has procured for it the name of the Convent of "ihe Pulley.

In the port there was a very large hoat of a beautiful construction. Its poop was ornamented with sculpture: it was pierced to carry sixteen guns; but for its mast, like the other vessels of the Nile, that is to say, with its sails in the form of hares-ears, fastened to yards of an enormous size, it might have been taken for a corvette. It was built under the direction of a certain Achmet bey, but he could never navigate it, except at the season when the river was at its greatest height.

On the 6th we proceeded to Siont distant from Manfelont a little more than five leagues. The Nile winds about at this place, and its navigation VOL. 111. 
is difficult and dangcrous. I met with the agent of Ali, Kiaschef of Manfelout: he was a fat countryman, full of frankness and gaiety. He conducted me to his master's house, and obliged me to take possession of it. He made provision with the greatest attention for all my wants, and promised to come frequently to see me. This house was spacious, and well laid out; in front there was a large enclosed court. Excepting the porter, no person inhabited it. We could not have been more comfortably lodged, nor, at the same time, more tranquil, or in greater security; the house of a Kiaschef being a respected asylum.

I had no great reason to be pleased with my boat's company. Having besides a design of passing some time at Siout, I gave my reis his dismission. He acted like all other bad servants, who complain incessantly of the serviccs exacted of them, and yet make supplication to remain, when you seem to entcr into their views by discharging them.

Siout is one of the largest cities in Upper Egypt. It is built at the distance of a quarter of a league on the west side of the Nile, on an artificial eminence, and close to a stecp mountain. A canal conducts thither the waters of the river, which you cross by a very preity Gothic bridge of three arches, composed 
of freestone. Its site is the same with that of the ancient city of Lycopolis*, where they worshipped as a sacred animal, not the wolf, for there are none in Egypt, but the jackal, which seems evidently to have been described by Herodotus, when he says, that the wolves of this country are very little larger than fuxes $f$. There can remain no farther doubt on the subject, when w' read the passage of Eusebius, quoted by citizen Larcher, in his notes upon the translation of Herodotus. "Others say that "the Ethiopians having made an expedition " against Egypt, were put to flight by an immense "multitude of wolves, and that this adventure "gave rise to the name of Lycopolitus, given to "the nome where this happened." It is well known, in reality, that the nature of jackals is to assemble themselves in great bodies.

I presented myself to the Kiaschef in command, called Daoud, with the letters of Mourat Bey. I met with a very kind reception from him. Wishing to procurc for myself as much consequence and protection as $I$ could, in a city where $I$ intended 10 sojourn for some time; I visited also

* Pocock believed that Siout was the site of Antœonolis, although Ptolemy has placed it on the eastern shore. Mr. Bruce (Travels to the Sources of the Nile) conceives Siout to be erected on the ruins of the ancient city of Isiu.

† Book ii. page 67, transl. by citizen Larcher.

t Prepar. Evangel. lib. ii. tom. i. page 50. B. C. 
Ibrahim the Kiaschef, who was overseer of the gathering in of the taxes due from the caravans of Nubia. This was one of the best men in the world.

The Jatter lent me his horses for the purjose of visiting those mountains which form at the back of Siout, an amphitheatre of rocks and of sterility, the foot of which is a full quarter of a league from the city. 'The other side of this mountain which looks towards the Nile, appeared at a distance, as if it were pierced into holes of different forns. These are openings into excavations hewn out in the rock, which is calcareous. Some of these entrances are in the form of an arch, others in that of an oblong square. They are of a fine workmanship, and crowded with symbolical figures, among which you may observe, without as well as within, that of a man of the natural size, with one hand leaning on a stick. The greater part of these cavities form very spacious halls, and nearly thirty feet in height. The interior of some of them is covered with hieroglyphical figures and characters, which are almost totally effaced by the hand of time. The remains of painting may be still distinguished on the ceilings, and in the cavities of the figures. These halls receive the light through airholes formed in the rock; they have also in them deep wells hollowed in a square form; it is impossible 
sible to see within them, or descend into them. I have visited four or five of these vast caverns, and I do not believe that there are any more of them on the opposite side of the mountain in the neighbourhood of Siout; but they are surrounded with a number of small grottoes, the openings of which are circular, whereas those of the large ones are all in straight lines.

These excavations, so numerous in the greater part of the mountains of Thebais, have appeared very extraordinary things to our travellers of no very remote date. Paul Lucas beheld there the habitation of the first men after the deluge, and, consequently, the first cities of the world*. Vansleb, always bordering upon the marvellous, and disposed to believe in sorcery, heard strange roises in them, and he had great difficulty to recognise in them the workmanship of human beings $\downarrow$. No. thing, however, appears of more easy comprehension than the destination of these subterraneous places. It is well known with what care the ancient Egyptians preserved their dead, and the attention which they paid, in order to keep them from corruption. The plains, so much the more precious for the purposes of agriculture, that they are there narrowed, were not proper for the sepulture of men

* Voyage in 1714 , vol. ii.

+ Nouv. Relat. d'Egypte, many passages.

$$
\text { E } 3
$$


whom piety wished to eternize even after their annihilation. The humidity which the watering necessary to fertility there diffused, the labours of cultivation, are mcans of corruption and disturbance, which the religious system of the Egyptians made it a duty to avoid. The dry and barren mountains with which the plains are enclosed, presented a certainty of preservation and of repose, and it was natural to deposit there the inanimate, but carefully prepared remains of persons beloved or venerated. The stone of this rock is soft, when it is not separated from the mountains and exposed to the air, which gives it a firmer consistency; hence it was not very difficult to dig it out; and what was taken from these excavations afforded sufficient materials for erecting habitations. It may be farther observed, that it is in the neighbourhood of great cities that the back of mountains is hewn into such numerous openings. It is then out of doubt that these are so many quarries opened to scrve as places of sepulture to the inhabitants of ancient Egypt, and that the beautiful caverns of the mountain of Siout have been the catacombs of the Lycopolitans.

At the foot of the mountain is an enclosure consecrated as the burial-place of the Maliometans. It had been newly whitewashed, and its zig-zalg construction, in a sort of checker-work, rendered the appearance of it picturesque and very pleasing.

I found 
$I$ found again at Siout the same kinds of birds which have established themselves in the other cities of Egypt, that is to say, kites, sparrowhawks, percnoptères, very tame turlle-doves (a pair of these birds built their nest on the shelf of a little window of the apartment which I occupied), sparrows still more tame, for they come into the houses, penetrate into the chambers, and almost perch upon the inhabitants, to seek for something to eat; and, finally, a multitude of lapwings. All these birds formed at Siout a second population, not less numerous, but far more peaceable than the other. 


\section{CHAP. XLI.}

Practice of physic in Egypt-Peculiarities on this sulject-Egyptian filysicians-Species of leprosy - Violent disorder of the eyes, with which the author was attacked-Rents of the houses in Egypt -Circumcision-Rain in Upper Egypt-Researches in quest of treasure-Perfidy of the $S_{y}$ rian Interpreter.

Mr fame as a physician had acquired for me great renown. From all quartcrs people came to consult me, and the higher orders called me into their houses. Every body wished to try the skill of the physician of a sultan of Europe, beloved by Mourat Bey, and who had undertaken, by the commands of Scheick el Belled, a journey to Said, for the express purpose of attending an Arabian prince, the most powerful one in Egypt: Another attraction, which did not fail to augment the crowd, was, that consultation, visits, and even medicines were all to be had gratis.

But the science of physic, in these countries, is practised in quite a different manner from that in use amongst us ; and a medical professor, the most approved by the most cclebrated of the faculty, 
would pass here for a blockhead; he would even find himself very much embarrassed.' In truth, what could he say to a patient who would only present him his pulse to feel, who would not reply to any one of his questions, and who would refuse to point out what part of his body he feit out of order? If the skilful physician should appear to hesitate upon the mere beating of the artery, respecting the nature of a disease; if he should allow him. self to interrogate the sick man; if he attempted to enter into fine and long rcasonings, sometimes as obscure to him who listened, as to him who utters them, there is no room to doubt he would be rejected as a man destitute of knowledge, unworthy of confidence, or of the name of a physician. What would become of him, if, stedfast in the principles and in the practice of his art, he were to prescribe some of those remedies so much prized in Europe, and which are not taken by the mouth? He would be attacked in the most violent manner, and he might estcem himself happy, if, in his cndeavours to escape, he came off with his life. The Egyptians, as well as the Turks, hold remedies of this sort in abomination, and a proposal to make use of them is, in their ejes, an insult of the most serious kind. I never can forget the adventure which befell a French surgeon belonging to a vessel which anchored in one of the ports of Caramania. The Turkish Aga, commander in that place, 
place, called him in. Hesuffered, he told him, a very severe pain in his head. The surgeon was inconsiderate enough to prescribe for him that which a physician in this country must not presume to mention. On a sudden the Mussulman was in a fury, that in order to cure a complaint in the head, an application was to be made to a part diametrically opposite: he drew out his sabre, arose from his divan, loaded the Frenchman with imprecations, and would have struck him with his scymilar, if he had not found means to evade the blow.

But such mistakes as these are not the only dan. gers to be encountered in the practice of physic in Egypt. If it happens that the sick person sinks under his disease, his physician must not expect the same indulgence which, in Europe, charitably removing from him every kind of reproach, contents itsclf with ascribing the death of the patient to the incurable nature of his disorder, or to the patient himself. He is regarded as an assassin. The family, the neighbours of the victim, even the populace, always disposed to rise up against foreigners whom they hold in abhorrence, unite together; the massacre of the physician succeeds almost immediately the loss of his patient; and he is made a sacrifice to the manes of the dead, and to the rengeance of the living. 
On the other hand, if the physician has the misfortune to be called in by a man in power, that which would be in our country a source of rejoicing, of importance, and of riches, becomes there a source of perpetual terror and dangers. He should diligently endeavour to shun an honour so perilous; but if he cannot escape it, he must either cure his too much exacting patient, or lay his account with dying himself. A most cruel alternative undoubtedly, but which renders the trade of quackery very rare here, and so common in other countries, where they are allowed to kill with the most perfect resignation. Does a remedy given to one of these same powerful men prove iroublesome to him ? The physician is ordered in: he is obliged to remain during the operation of the medicine; he is informed that he must answer with lis head for any unpleasant termination. In the moments of pain, looks of fury are darted at him, and the wretched physician, more clisordered than the sick man himself, awaits, in mortal agonies, the issue of the operation of a medicine which his conjectural skill could not permit him to assert would be suc. cessful in its effects.

It will easily be conceived, that I observed every precaution, in order to shelter myself from the dangers with which the practice of physic is surrounded in those barbarous countries, where it was imagined that a man is a physician only in order to cure, 
and where he is so far from mreting that praiseworthy condescension which, with us, renders the employment of a physician the easiest and the happiest of professious. I knew that, with the exception of some peculiar maladies, the symptoms of which are evident in the exterior, the Arabs and the Egyptians acknowledge but three sources, or rather three sorts of disease; the bile, saffra; the blood, dem; and the cold, berd. It is useless to enter into any other explication with them, and above all, to attempt to reason. You have only to feel their pulse in silence, as they in silence hold it out to you; and after some mute reflections, often very perplexing, to pronounce one of these three words characteristic of their diseases. If you guess right, exclamations on your profound skill are a mark of admiration which gives you new life. If, on the contrary, you are not successful in this species of divination, a negative motion of the head, which accompanics a countenance on which contempt is depicted, is equivalent to these words: "Go, take "thyself off; thou art an ignorant fellow."

Distinctions so little complicated in practical medicine, are very happily not extremely difficult to hit. The appearance of the consulter almost always carries an exact indication. A yellow complexion denotes bile; red announces blond; and pale becomes the sign of cold. Into these three divisions 
alone all diseases are classed, and you have no occasion to perplex yourself either with their gradations, their names, or their numerous subdivisions. I was so well versed in these forms of Egy ptian prac1:ce, that, after having gravely taken the wrist presented to me, I could pronounce boldly, and it very rarely happened that I was mistaken in $\mathrm{my}$ conjecture. To this method of practice I at times added a little deceit. I pretended not to understand a word of Arabic. My interpreter was always by my sick; I however understood the language sufficiently to lay hold of those details which were given unsuspectirgly in my presence, in the persuasion that I did not comprehend them. This address was, without doubt, very allowable, when I had to choose between eminence and the most dangerous consequences. This deception, which partakes a little of quackery, and which detractors from the art of medicine will not fail to call inseparable from the profession of a physician, was of great service to me at Siout, on an occasion when an attempt was made to put my skill to the test.

The Kiaschef one day sent and requested me to come to his house; he was in his hall of state. Twenty other officers of the Mamelucs werc ranged on each side of him on the floor of his divan, and all of them, or I deccived myself, appeared to crijoy perfect health. When I was introduced, the Kias- 
chef announced that I was the physician of Mourat Bey and Ismain-Alou-Ali; that it was necessary to make trial of the whole extent of my knowledge, and that, moreover, they might speak with perfect freedom before me, for I did not understand Arabic. He began by declaring, that being in the habit of losing some blood once every year, he had for the first time neglected that precaution, and that he was disordered in consequence of it. His next neighbour said, that a sudden cold had seized him, from having passed the night in a boat, and that it occasioned him great pain. A nother was choked with bile. They all explained, in a high tone of voice, and in their own way, the real or imaginary cause of their diseases, that each of them might be in a condition to judge if my science could enable me to discover, or rather to divine them.

The Kiaschef made me approach him, and held out his wrist to me: he waited till I pronounced my opinion, with the impatience of curiosity. I gave myself the air of meditating upon it for some portion of time before I pronounced the oracle; I then informed the Kiaschef, by the interpreter, that it was necessary he should be bled. I assured his neighbour that his dreadful pains were the consequence of a cold which he had caught some little time before. I advised the third to get rid of the bile which choked him; at last, when I had made 
the tour of the circle and of wrists, each one received what he conceived to be the most convincing proof of my incomparable skill. The admiration which it excited was unanimous. Every fist, shut and closely clenched, by a little perpendicular motion put forward from the body, the sign of applause among the Turks, testificd the general approbation; and eulogiums, short among a people frugal of their words, but very expressive, were repeated by turns. A success so brilliant had greally enhanced my medical reputation, and spread the fame of my wondcrful knowledge all over Siout and its environs.

Not that there were in Egypt no natives of the country who dealt in empiricism, but they were held in very little estimation, and their destitute condition demonstrated sufficiently that they exercised a bad trade. When I made my appearance any where, the persuasion that a stranger nust possess greater talents than them, very soon set them at distance, and their patients abandoned them to resort to my superior illumination. But I must say, to the honour of the physicians of all nations, that there is one country where jealousy never takes possession of their souls, and where the success of another is only a source of satisfaction and of confidence. Not only did the Egyptian physicians feel no enry from the splendour of 
nily reputation, but they came openly to consult me, and made me the confident of the uneasiness which some of their patients occasioned them.

One of the modes of cure the most in vogue among the Egyptian physicians, is the burning the part affected. This species of caluterization is the basis of the science of physic with the natives of the East. It was known to the ancient Greeks, and their plysicians practised it, and called it Arabic burning; but they used it with great discretion, and it was in their hands a very powerful remedy. The Egyptians apply a medicine so violent upon every occasion, and without any regard to the part to which they make the application. I have seen, for instance, a man whose eyelashes, and a part of his eyebrows, had been scorched with a red-hot iron, in order to cure him of an inflammation in his cyes. Another, who was attacked with a pain in his stomach, had likewise submitted to this cruel operation. To the pit of his stomach, and directly opposite upon his back, a piece of red-hot iron had been applied, of the size of a crown-piece. But the burning physician had had, to all appearance, too heavy a hand, for the stomach and the back of the wretched man were laid open, in such a manner, that his body was, so to speak, bored through. The great heat, and the want of dressing to these wounds, had made them degenerate into the most 
filthy ulcers, far more dangerous than a pain in the stomach. A man attacked with a disease in his lungs, was corered with exterior sores; and a dropsical man who came to me for advice, carried, to no purpose, on his belly, more than fifty wounds, made by fiery cauterizations of the size of a crown-piece.

It is not astonishing that the Egyptians, with their three divisions of diseases, should frequently deceive themselves respecting the nature of those with which they are affected. An officer of the Mamelucs, a young and handsome man, came to consult me. He was so infected with that dreadful disorder so generally diffused over these countries, and which poisons the very sources of life, that he had lost almost entirely the power of propagating his species. His situation was horrible. I gave him to understand what his malady was, but he was very much displeased at it he maintained that $I$ deceived myself, and that it was nothing else but bile.

Somctimes the practice of physic procured me very extraordinary revelations and proposals. I received a visit from a rich man of Siout. He drew me aside in a very mysterious manner. He bore impatiently the presence of nuy interpreter, to which, however, it was necessary he should submit. 
After a great many turnings and windings, he told me that a beautiful slave of a harem carricd within - her too evident tokens of a clandestine and imprudent amour. The master, a man in power, who had been for a long time at Cairo, had announced his return. Apprehension and disquiet reigned through the whole house; every one dreaded the inevitable fury of the owner of it, and the most dreadful calamities must of necessity be the fatal consequences of a very natural accident, but which is never pardoned in these countries. He concluded by proposing to me, that I should make the approaching cause of these great misfortunes to disappear, and by promising me a considerable recompense. "My profession," said I to him, "is " to prescrve life, and not to take it away; go carry " elsewhere, if thou darest, thy proposals and thy "recompenses." Notwithstanding the decided tone of voice in which I gave my reply to the interpreter to transmit to him, this man persisted, and he thought to persuade me by an argument which he deemed invincible. "Is it not true," said he, "that it is better to deprive a being of life who does "not hnow what it is, than to expose several who "cnjoy' it to a certain death? for the return of the " master will not fail to be the epocha of the mas"sacre of eight or ten persons, among whom will "be the unfortunate slave." Quite surprised that s?ch an argument as this did not engage me to become 
come myself an assassin, in order to prevent others from being so, and, above all, that his handfuls of gold did not tempt me, my gentleman quitted me very much displeased, and I never leard whether the fears which he manifested were well grounded; it would indeed have been a very imprudent act in me to procure information of it.

In the number of discascs which I have liad occasion to prescribe for, I observed a very singular one on the skin of an inhabitant of Siout. His complexion, like that of all the other natives of the same southern cantons of Egypt, was of a deep brown. But about five or six years before, a part of this blackish skin had given place to another perfectly white; these white spots were spreading more and more, so that when I saw this man, his face, his arms and hands, and his whole body, were covered, and, as it were, marbled with large flakes of brown and white; the blackish skin was disappearing gradually, and it is to be presumed that his skin will have become completely as white as milk. He did not experience, in other respects, any pain or uneasiness.

This disorder is a species of leprosy. It is, according to all appearance, the same with the bokak or behaq of the Arabs*. When it spreads itsclf all

* See the Description of Arabia, by Niebuhr, page 120, and the note of Forskal on the following page. 
over the body, the Arabs, as Forskal reports, call it burras. The samc author adds, that the spots of this kind of leprosy are never visible on the hands nor around the navel; but my observation has ronvinced me to the contrary; for the man of Siout had these very parts overspread with white spots. This disease is neither infectious nor fatal. Nicbuhr says that a negro who had been attacked with it at Mocha was relicred, but not cured of it, by the use of sulphur.

Whilst I thus employed myself, pretty much against my will, about the health of others, I was attacked in my turn with a violent disorder in my eyes, of that kind which the Greeks have named chemosis. The ball of one of my eyes started from its orbit; the membranes, swelled and extremely inflamed, covered it totally; it was so frightful to behold, that no one of my attendants durst look upon me. A hurning fever consumed me. I endured insupportable agonies. Slcep never closed my swollen eyelids; it was impossible for me to lie down; for, in that position, the eye pressing upon the abscess which had formed itself at the bottom of its orbit augmented my sufferings.

It is upon these occasions that the traveller, at a distance from every species of assistance, must collect together all the knowledge he may possess, and 
the resources of his fortitude. Very nearly blind, for the other eye, though less disordcred, was very much inflamed, Ihad no longer the powcr of bleed. ing myself, which I had done in other circum. stances. An Italian missionary resided in the environs; I sent to entreat him to perform this operation for me. He employed that kind of lanect with a spring which is made use of in several parts of Italy and Germany, and which is known under the name of fleam. To put the finishing stroke to my misery, the awkward monk, in attempting to bleed me, broke his lancet, and left the point in my arm. He protested to me, that this was the first time such an accident had happened to him, which afforded me neither pleasure nor consolation. I was obliged to undergo a pretty long operation, in which my detestable surgeon slashed my arm in order to extract the fragment of the fleam. At last the earnest desire which I had to be bled, made me resolve, although with regret, to permit him a second time to make an attempt to draw blood from me with a better instrument, and, above all, with grcater skill. The monk, not ivithout many delays, which made me apprehend some still greatcr accident, at last succeded in giving me a copious bleeding, which afiorded tne no relicf.

I reccived as little from cmollient calaplasms, the torrents of cooling draughts, and the other re- 
medies which physic makes use of in these discases. My sufferings, instead of abating, continued to increase every day. Wearied with my position, I ordered several poppy-heads to be brought to me ; these I had boiled in some water, which I drank when night came on. In a very short time I experienced the effects of this narcotic. I was soon asleep, and whilst slceping I disencumbered myself of the props which kept ine upright, I fell stretched out at full length, and after a profound slumber of fiftecn hours I awoke again without fceling any pain : the eyc had returncd into its socket entircly cleansed; in a word, complctely cured. There only remained a weakness in my eyes, but this was not of long continuance; and my sight became, in a short time, as good and as clcar as it was before.

During my convalescence, I was under the necessity of changing my lodging. Ali Kiaschef, the owner of the house which I occupied, arrived with his harem and all his train, and I yielded up the place to him. A small house was hired for me; in front there was a court, which, to tell the truth, was not a very spacious onc. I occupied the whole of it, and for the rent of this habitation I gave only two medinas, or rather more than a penny a day; and it is to be presumed, that, in my quality of foreigner, I was male to pay a higher price than another would have done.

I often 
I often saw passing in the streets of Siout, those processions which accompany the ceremony of circumcision of children. Those newly initiated young people are carried through the city in great pomp, clothed in the most splendid dresses, and mounted on horses adorned with all the trappings of luxury. Two men support each of the children, a third leads his horse by the bridle, and crowds follow them. The procession is opened wiih hautboys and cymbals, after them come several flags of different coloured silks. There are some white bordered with red, others are black or green, with a white border. In the midst of all, the name of God, and the Mussulman's profession of faith, are imprinted in Arabic characters. Priests, singing passages from the Alcorais, surround them; behind them marches a man bearing a kind of tabernacle, adorned with diamonds and streamers, and containing, without doubt, the sacred book: he precedes the group of the circumcised, behind whom one or several camels are led, carrying a pair of kettle-drums, the basin of one of which is much less than the other, and both the sound and the measure of them are very monotorous. Women, who close the procession, mingle incessantly with the roaring music of the instruments a shrill sound, which is accompanied by long rollings of the tongue, and this is the exclamation of joy among the Egyptians.

$$
\text { F } 4 \text { During }
$$


During my residence at Sioul, a circumstance happened, which was looked upon as very extraordinary. This was the descent of rain; so uncommon in the southern parts of Egypt, that it may be said, without the fear of being in an crror, that it never rains there. However, on the $15^{\text {th }}$ of A pril 1778 , with a violent south wind, the sky was cloucied during the whole day, and from time to time a litule rain fell; but at night a storm arose, with a torrent of rdin, accompanied with lightnings and some claps of thunder.

Daoud Kiaschef, commandant of Siout, who had an inclination to put my talents in physic to the test, of which he had conceived a high opinion, imagined that I must also be a dealer in magic, and that the most hidden treasures, not being able to resist the power of my art, left their most secret abodes to spring into my pocket. The Mameluc was very desirous of sharing, at least, the inmense profits which such a valuable science must of necessity procure for me. A mosque in the city passed in the minds of the inhabitants as the cepository of riches concealed from every eye; he surnmoned me secretly, and made me promise to go to this temple, in order to discover, by my surceries, the place where the gold was to be found, which we were to share together. Every thing which I could say to undeceive him was in. 
sain; and perceiving that he grew displcased, I allowed myself to be conducted into the mosque, and on my return I assured him that the report spread concerning the pretended treasures, said to be concealed there, was an imposture, and that not an atom existed in it.

I profited by this opportunity to reproach the Kiaschef for having endeavourcd to deprive me of my Syrian interpreter. With thic intention of having an explanation on this subject, I had taken with me a young Alexandrian servant, who, understanding the lingua Franca, could, though with some difficulty, serve me as an interpretcr. Daoud appeared to be very much surprised: he scnt for the Syrian, who had not the assurance to maintain in the presence of the Kiaschef, what he had accuscd him of to me with the utmost degree of perfidy. Indeed he had the audacity to assure me that Droud wished him to enter into his service, and that he had received from him, even in writing, the most flattering promises. But he was obliged to acknowledge his imposture, and the irritated Kiaschef was going to order the bastinado to be applied to the soles of his feet, if I had not cntreated a pardon for him, which I had some difficulty to obtain, and only upon condition, that if the same man gave me any new cause of dis-

plcasure, 
pleasure, I should give him notice of it, that he might himself have the charge of punishing him.

On more than one occasion, my companions and I had remarked that this Christian of Syria betrayed us. I was going to have an evident proof of his vile and dangerous spirit of intrigue, and, in a very short time, I convinced myself of his deep villany. It was indeed merely by chance that I escaped the dreadful snare which had been laid to destroy me and my companions, as will be related in the following chapter. 


\section{CHAP. XLII.}

Preparations for a journey to Sennaar-Conspiracy between the chief of the caravan of Nubia and the Syrian interpreter, to assassinate the author, obliged to renounce the journey into AbyssiniaCarazans of the Nubians-Monkeys-Perroquets -Nubians-Visit to a camp of Bedouins-Percnopters-Cophts-Repast-Rubbers for the feet -Apricots-Water-melons - Melons - Dates Hemp, its intoxicating quality.

I HAVE said that one Ibrahim Kiaschef was employed to oversee the taxes to which a caravan of the Nubians which had arrived at Siout was sub. jected. I saw him frequently; he was of a very gentle character, and he expressed a great deal of affection for me. The important service which he rendered me is a proof of the friendship of that honest Mameluc.

The journey into Abyssinia did not for a moment quit my imagination. I met, at Siout, with the most favourable opport unity for undertaking it. A caravan of negroes were on the eve of departurc from thence in order to return to Semuar, the capital of Nubia, from whence I proposed passing into the country of the Abyssinians. My preparations 
rations were made. All my arrangements had becn concerted with the black chicf of the caravan; to conclude, I was on the point of commencing this long journey, when an incident happened which obliged me to renounce it for cver.

The employment of Ibrahim gave him some authority orer the Nubians of the caravan. I engaged him to use his credit to make a treaty for my journey with the chief or Kabir; this is the name given in Nubia to men in power, from the Arabic word kelir, which signifies great. The Nu. bian demanded at first an exorbitant sum. We had several conferences at the house of Ibrahim, on this subject, through the medium of the Maronite interpreter. But the Kabir not choosing to abate his demands, I quitted him without coming to any terms. Some days after, this same Nubian came to me at my own house: he was grown more rcasonable. His price, though he had diminished it grreatly, was still excessive: however, he wished to speak to me in private. After having dismissed every body except the interpreter, he asked me with a great appearance of mystery if I posscssed any drugs which were powerful love-potions. He assured me that medicines of this sort were alone held in estimation in his country, where, said he, every action, every thought, has a relation to the pleasures of love; and that nothing might be wanting 
ing to his gross imposture, he added that his king had expressly commanded him to bring him some strong stimulants of that nature. It was a very improper time for him to think of such provision, at the very moment when the caravan had already, so to speak, one foot in the desert. I did not pay very great attention to falsehoods, of which the people of this country are not very sparing, and I replied to the Kabir, that, charmed with the pleasant and important occupations of his Sennaarian Majesty, I would employ all the resources of my art in order to prescrve lim, as well as his subjects, in such happy dispositions. The negro appeared so well satisfied with my reply, that he instantly abated, at one stroke, the half of the price which he had demanded; so that reckoning the provision which I must have made, a journey so long and so difficult would not have amountcd to more than 150 patacas, or about 800 francs ( $33 l .6 s .8 d$.).

I flew to inform Ibrahim of the news which gave me so much satisfaction. But he did not appear to partake of my joy: he congratulated me very coldly, and, in a tone of solicitude, he recommended it to me to conclude nothing without his interposition.

A ffairs had changed in a very wonderful manner. It was no longer necessary for me to express the desire 
desirc I had of departing with the caravan; it was the chief of the caravan himself who solicited me, who persecuted me to take my departure with him. He came to see me several times in a day, and every day he became more earnest in his importunitics. Promises the most flattering which he could devise, were not spared; he assured me that I would be very well received at the court of his king. In the description of the comforts which I was to enjoy there, this sensual and savage beast told me that I should eat the whole day long, and that there the most beautiful women would be devoted to my pleasure. I spoke to him one day of the assassination of M. du Roule, whom his compatriots had massacred when Maillet was consul. He did not know immediately what reply to make; he wished to deny the fact, and afterwards to justify it, by saying that the French physician was an ignorant fellow, and that besides he was never introduced to the king. This was false, since it was actually at Sennaar that du Roule lost his life. At last, to remove all difficulties, and to testify, as he said to me, his extreme desire of conducting me into his country, and of presenting me to the black monarch; from whom I might be certain of a welcome reception; the Kabir, after having reduced his demand to the moderate sum of fifty patacas ( 275 francs, or about cleven guincas), for which he engaged to furnish camels and provisions, concluded 
cluded at length by declaring that he would exact nothing of me for my journey, as he was certain that his sovereign would give him a sufficient recompense for the service he was going to render him by conducting me to his court.

An alteration so extraordinary, gave me indeed some suspicions, which my companions, less eager than I was to penetrate into the interior of Africa, had not been so slow in conceiving. However, the extreme desire I felt of availing myself of a favourable opportunity to exccute a project formed so long beforc, and setting aside every consideration which could have diverted my mind from it, I was on the point of giving my word to the Kabir to attend him, when I received a message from Ibrahim, who invited me to come to his house attended only by my Egyptian servant.

"Thou must renounce, at least at this period," said the Kiaschef to me, "thy journey to Sennaar. "What thou toldest me of the importunities of the "Kabir awakened suspicions in me. I would not "speak to thee on the subject before I knew whe" ther or not they had any foundation : at present "I am assured of the certainty of a horrible con" spiracy formed against thee and against the other "Francs who accompany thee. I knew that the "dog of a Syrian, who serves thee as an interpre- 
"ter, had frequent conversations with the Kubir. "I ordered them to be watched and listened to, " and I give thec to undersiand, that the design of "these twe rascals was, when thou shouldest have "reached the desert, to massicre thee and thy "companions, and to share thy spoils, which the " interpreter assurcd his associate were invaluable. "In order that not a doubt may remain with thee " respecting the atrocious perfidy of that $d o g$ whom " thou hast cherishcd to betray thce, I will order " him to come in, and oblige him to acknowlcdge " every thing in our presence."

The Syrian arrived of course a moment after. Yis appearance was that of self-satisfaction; the stupid grin which he usually worc, widened his mouth. He imagined that the young Egyptian not being qualified to support an important conversation, we had becn obliged to have recourse to his talents. The Kiaschef addressed a few questions to him, which very soon clouded the tokens of his joy: he turned pale and trembled; but when Ibrahim concluded by declaring, that it was no longer time to dissemble, that the Kabir had given him the most minute details of his perfidy, he fell as with a thunder-stroke at the feet of the Kiaschef. To the confession of his crime he added some circumstances which were not known, accusing the Katir of being the author of the plot, and of what 
lie called his own misfortune. Jhrahim assuming a terrible tone, commanded the villain to be caned to death. I permitted terror to convey perturbation, and the most cruel pangs, into the soul of this base rascal; but when I saw the instruments of punishment prepared, I entreated he might be furgiven. Ibrahim, indignant, would not listen to a petition in his behalf, and would only grant it on the word of hunour which he made me give him, that I would myself punish the culprit. I expressed my warment gratitude to the Kiaschef, and I drove from my house the Kabir, who not knowing wliat had just come to pass, was come once more to urge me to depart with him. In this manner my project of a journey into Abyssinia was defeated.

I will not quit this subject without speaking a few words respecting those Nubians who, from the extrenity of Africa, come to bring into the capial of Egypt those valuable commodities which wature seems to have placed in their countries, to compensate the insupportable heat of the climate and the oppressive scorching heat of the sun. And, in the first place, I must rectify the mistake of an English traveller who visited Upper Egypt some years before me, because history and commerce are interested in it. Speaking of Siout, Mr. Bruce says, that the caravan of Sinnar came there formerly, and that those who composed it rendezvoused at yOL. III. G

Siout 
Siout and at Munfelout, and placed themselves un= der the protectivn of the Bey who resided therr; afterwards entering by the south east into the desert of Libya, they procieded forward to Elmuath, which is the great Oasis of the ancients, and from thence crossed the immense desert of Selima These caravans from the iuterior of Africa have not ceased to travel on the shores of the Nile to Siout and to Manfelout, and that which I have just related, proves that they readezvous there.

Besides gold and other merchandise, these Africans bring also animals, such as inonkeys and perroquets, which form the amusement of rich people at Cairo, and one of the resources employed by puppet-show men in order to attract the multitude. Monkeys, which, like a number of other animals, were one of the objects of veneration to the Egyptiansw, are not natives of their country. The inhabitants of those citics where they were considered as sacred, went into Ethiopia in search of this agrceable species of divinities. It is, besides, from this country, and from the land of Yemen, the forests of which, according to the report of Niebuhr, abound with this sort of animals, that they are brought into Egypt as an article of commerce. I never saw

* Travels to the Sources of the Nile, translated by Castéra.

+ Isis enim Serapisque et long â simia caudế, says Frudentius, in making an esumeration of the gods of the Egyptians. 
there above three sorts: the baboon, the same which the ancients called the cynocephalus (dog-headed) monkey*, the macacar ${ }^{*}$, and the aigrette + .

That specics of perroquets, wijich the Nubians bring in great numbers to Cairo, is that of the parroquet with a rose-coloured ring round its neck \$; its A rabic name is dourra, which is also that of a large kind of black millet cultivated in that country.

The Nubians of Dongola and of Semnar are well made and tall in stature. Their skin is of a beautiful shining black. They wear, like the Turks and the Arabs, a beard and whiskers. On this subject I shall remark, that in France I have met with very well informed persons who did not know that the Negroes had beards. Although, in general, it shoots later with them than with the Egyptians, and though they are not so well furnished with it, they seldom fail to have a pretty thick one on their faces. The chief of the caravan at Siout, as handsome as he was rascally, bore on his chin a long and thick beard.

* Le papion ou babouin proprement dit. Buffon, Hist. Nat. des Quad.-Simia spliinx. Lin.

† Macacque. Buffon, Hist. Nat. des Quad,-Simia cyronmulgus. Lin.

$\ddagger$ Aigrette. Buffon, Hist. Nat. des Quad.-Simia aygula. Lin.

§ Buffon, Hist. Nat. des Ois. \& pl. enlum. No. 551.Psittacus Alexandri, Lin. 
As he was at that time advanced in years, this beard was of the most beautiful white, as wel! as his whis. kers; and this colour, in contrast w ith the ebony black of the rest of his figure, proluced a singular effect, which was far from being disagreeable.

These same Negroes follow the religion of $\mathrm{Ma}$ homet, but they add to it practices and supersutions which are foreign to it. They go almost naked. It is a luxury to wear a long shirt of gray cloth, the sleeves of which are turned up under the armpits, by which means the arm is left entirely bare. They have usually several litule leathern cases fastened to the fold of the left arm. These are so many pockets in which they keep money, tobacco, and other artic!es for daily use. 'To the bend of the right arm is fixed a poniard, of which the handle and sheath are likewise of leather. On a journey they are armed besides with a long sabre, the blade of which is straight and thin. They are all bare-headed, and they plait and dress their hair or their wool in different manners. I have seen some among them whose head-dress was arranged in such a way as to give it a complete resemblance to those wigs which at that period were denominated perruques à l'Angloise. Those of the Nubians who carry on commerce speak Arabic, but they have among themselves a particular idiom.

The 
The great reputation which $I$ had acquired as a pluysician extended far and wide. A Scheick of Arabian Bedouins, encamped in the environs of Marfelout, wrote to the Kiaschef of Siout to entreat him to engage me to visit his camp. I promised to go if they would furnish me with horses. Two days after the Bedouins brought me some which were very beautiful, and we departed under the guidance of these same Arabs in the aftcrnoon. We directed our course to the north-north-west, and arrived at night at a village, of which the Sheick el Belled, previously apprized by our conductors, received us very kindly. Near this village I saw a great many percnopters. I have observed that the colour of the plumage of these birds was not the same in all the individuals. Some, and these the most numerous, are of a dirty white, others of an ash gray, and the upper part of the body and the wings of some are of a blackish hue.

The following day, at ten o'clock in the morning, we entered the Bcdouin camp, where I was expected. A great number of tents were erected on the sand at the foot of the chain of mountains parallel to the western shore of the Nile, in the neighbourhood of a village called Tetalie, and at the clistance of about four leagues from Manfelout. The Siheick was employed in settling some accounts with his secretaries; I had to wait some 
time before I was introduced to him. It was not for himself that he had sent for me, but for an old Arab who had been blind for two years. It was a matter of astonishment through all the camp, when I was heard to declare that my skill did not extend so far as to operate miracles, and that nothing less than onc could restore sight to the Arab. I took lcave of the Scheick, who was called Mahmond, and of the innumerable quantity of flies with which the tents of this camp swarmed. I never had seen such an asscmblage of vermin in any of the countries I visited. I resumed the road to Sious by the route of Manfelout.

In these two cities the greatest part of the population is composed of Cophts. Most of them are occupied in the manufacture of blue cloths, in which they carry on a considerable commerce. Being theonly people in that part of Egypt who knew how to read and write, they were the stewards, the administrators, the secretaries, of rich or powerful men, and they understood perfectly, as well as those in other places, how to make an advaniageous use of the confidence and the incapacity of those whose property they had in their management. Several of them acquired great riches, but they had the good sense to use them with moderation, and entirely within doors. They knew too well the danger which they incurred, by openly displaying their 
opulence to the cyes of despots, who, accustomed to look upon the fortune of others as if it belonged to themselves, barbarously sport with the property and the lives of men.

One of the opulent Cophts of Siout insisted on giving me a dinner. The interior of his house was genteel and commodious: every thing there announced a man at his ease; but I no more saw a woman than if it had been the house of a Mussulman. The repast was served up with profusion; we drank copiously of some excellent datebrandy, which was presented every moment in small glasses of Venice crystal.

In other respects their manner of taking their meals is the same with that of the Turks and the Arabs. They are seated, with their legs crossed, around a table with one foot, in form of a large circular teaboard, on which dishes are placed, without either tablecloth, plates, knives, or forks. They make, with the right hand, the circle of the dishes, from whence they take successively, and according to their taste, little morsels with their fingers. The left hand, destined for ablutions, is unclean, and must not touch provisions. They sometimes transfer what they have taken from one dish to another, to form a mixfure of it; of this they make a large ball, which they convey to a

$$
\text { c } 4
$$
widely- 
widely-extcuded mouth. The poultry and the boiled meats are divided into pieces, and torn with the hands and nails. The roast meats are served up in little pieces, cut before they are put to the spit, and no where can you cat better roasted meat than in the countries of Turkey. The table does not afford an opportunity for conversation. They only seat theinselves to eat very rapidly; they make quick dispatch, and swallow with precipitation. They are not men whom the pleasure of society assembles together, they are brutes whom want and voraciousness collect around their pasture. The grease distils from each side of their mouths. The stomach sends forth frequent fumes, which they lengthen ont and render as noisy as they can. He whose hunger is soonest appeased rises from lable first. It is not regarded as a want of politeness to remain alone at the board, if your appetite is not perfectly satisfied.

During my abode at Siout I did not fail to frequent the baths, to which I had taken so great a liking, and which appeared to me very salutary. These baths are neither so handsome nor so well attended to as at Cairo. Besides the different manners of kneading the flesh, of suppliug the limbs, and of rubbing the body, the Sybarites of these countries take great pleasure, in their own houses, in having the soles of their feet rubbed with pieces 
oi pumice-stone. That which is the most esteemed for that purpose is of a blackish hue. They give it the form of a wedge cut with an edge on one side, and with a fiat surface on the other. This form is the most convenient for the hand of the rubber. The flat side, or the bottom, is striped with deep incisions, which give it the roughness of a large file, and which scrape the soles of the feet in a superior manner.

The picces of pumice-stone thus manufactured are called, in Arabic, el hakké. It is said that the best come from Palestine. The operation of having the soles of the feet roughly rubbed, is one of the luxuries of the Egyptians; but it is insupportable at first to Europeans, and it excites involuntary motions, startings which the sensibility of the parts occasions. After some time these delicate sensations subside, and they find at last some pleasure in the operation, especially when it is performed by an experienced hand.

The plains which surround Siout are remarkable for their abundance. The farinaceous plants in these comntries excite admiration by a rapid vegetation, and an astonishing quantity of produce. The orchards yield fruits of every kind. I ate there a great many of the nebka, a sort of plums which I have already mentioned, and which disap- 
jear from the markets about the beginning of April. You find there small apricots, the produce of trees planted in the open air*. They arc called mischmisch, and have an agreable flavour. They dry them, and afterwards dress them as sauce to meats. These dishes, which usually garnish the tables of the rich, are of the best sort which cone from Egyptian kitchens.

But that specics of fruit which, by its pulp and its cooling liquor, is the best qualified for allaying the inward heat which the climate excites, is the pastéca, or water-melon $r$. The cultivation of this is one of the most general and most prolific in Upper Egypt. The pastécas here are a great deal beiter than in the lower part, or even at Cairo. The markets are filled with them; and they sell at a very moderate price, by which means the poor, as well as the rich, have it in their power to cool themselves with their agueous and sugary juice. Their Arabic name is battech. These water-melons of Egypt are round, and grow to a very large size. Those of the best quality, when they are fully ripe, have a perfectly smooth rind of a deep and blackish green. Thestripes are slightly marked.

* Prumus armeniaca, misjmisj. Forskal, Flora Egypt.-Arab. page 67.

† Cucurbita citrullus, Egyptiis battich. Forskal, Flora Egypt.・ Arab. page 75 . 
The pulp is white near the rind, and red in the middle. Their seeds are flattened; their shell is black, and the interior of a beautiful white.

I have eaten at Sinut pastécas of another kind, which are called battech sädi. It differs from that which I have now described, in that its rind is less smooth, and of a whitish gray, the pulp in the middle of the fruit is of the most lively rose colour, the shell of the seeds hard, almost ligneous, and of an aurora-red colour. This species grows to a still larger size than that with a green rind; and its pulp, likewise, firm and brittle, preserves equally an agreeable coolness, and the same slightly sugared flavour. Both of them are wholesome and uscful food in climates where the heat makes the blood to boil, and gives sharpness to the humours.

From the commencement of the month of May they eat also a large quantity of melons, very beautiful in appearance, but in general of a very indifferent quality. They have, at the same season, very large pumpkins, of which the Arabic name is marrach. They cat likewise small green dates, the stones of which have acquired no consistency. But these fruits, delicious when they have arrived at maturity, are very bad before they are formed, although in that state they are very much to the taste of the inhabitants of Upper Egypt.

Hemp 
Hemp is cultivated in the plains of the same comntries, but they do not spin it into thread, as in Europe, although to all appearance it might be thus manufactured. It is, nevertheless, a plant very much in use. For want of intoxicating liquors, the Arabs and the Egyptians compose several pre. parations from this plant, with which they procure for themselves a sort of pleasing drunkenriess, a state of reverie which inspires gaiety, and produces agreeable dreams. This sort of annihilation of the faculty of thinking, this kind of slumber of the soul, has no resemblance to the intoxication produced by wine or strong liquors, and our language has no terms expressive of it. The Arabs give the name of keif to this voluptuous relaxation, this sort of delicious stupor.

The preparation from liemp, most in use, is made by bruising the fruits with their membranous capsules; they press the paste which results from this with honey, pepper, and nutmeg, and they swallow pieces of this comfit of the size of a nut. The poor, who charm their wretchedness by the stupefaction which hemp produces, content themselves with pounding the capsules of the seeds in water, and with cating the paste. The Egyptians likewise eat the capsules without any preparation, and they ningle them besides with the tobacco which they smoke. At other times they reduce only the capsules 
sules and the pistils to a fine powder, and reject the seeds. They mix this powder with an equal quantity of tobacco, and they smoke the mixture in a sort uf pipe, a very simple imitation, but coarsely executed, of the Persian pipe. It is nothing but the shell of a cocoa-nut hollowed and filled with water, through which they inhale a pungent and intoxicating smoke. This method of smoking is one of the most common pastimes of the women in the southern part of Egypt.

All these preparations, as wcll as the parts of the plant employed in making them. arc knowp under the Arabic name of haschich, which properly signifies herb, as if this plant were the herb, the plant, by way of excellence. The haschich, the consumption of which is very considerable, is to be found in all the markets*. When they wish to design the plant itself, unconnected with its virtues and its use, it is called basté.

Although the hemp of Erypt has a great resemblance to ours, it differs, nevertheless, in some cha-

* This denomination of herb has given rise to an error of M. Niehulhr. "The lasclick,", says he, " is a sort of herb which "MI. Forskal, and some others who have preceded us in the East, " have taken tor the leaves of hemp." (Description of Arabia, p. 50.) It is, nevertl.eless, very certain that the haschich of the Arabs is notling else than a species, or a variety of hemp, of which! have beer just giving an account. 
racters which appear to constitute a particular species. On comparing attentively this hemp with that of Europe, you observe that its stalk is much less elevated; that it acquircs in thickness what it wants in height; that the port of the plant is rather that of a shrub, the stem of which is often more than two inches in circumference, and numerous and alternate branches which clothe it down to the very root. Its leaves are also less narrow and less indented. The whole plant exhales a stronger smell, and the fruits at the same time are smaller and more numerous than in that species which grows in Europe. 


\section{CHAP. XLIIT.}

Tomieh - Aboutigé - Robvers - Tahia - CophiSick man, and the method in suthich the author repressed his arrogance-Catholic Cophis-The persecutions which they suffer-Engraved stones and medals_-Apples-Melons-Doum Sä̈di-Ppecies of palm-tree of Thebais-Different species of the leprosy.

After a considerable residence at Siout, during which I was ill half the time, I thought of continuing my route to the south of Egypt. But as there were in that port no boats ready to ascend the Nile, I was obliged to alter my mode of travelling. I hired two camels and six asses to convey me to Echmimm. We departed from Siout the 23d of May 1778 , a little before mid-day; and pursuing a road which sometimes conducted us toward the winding course of the Nile, and sometimes carried us to a distance from it, we arrived at Tomie? toward nine o'clock at night. This is a very small market-town, the residence of a Kiaschef. A very large number of date and other trces surround it; and this enclosure of foliage and verdure, so useful in tempering the ardour 
of a fiery sun, and in softcning the rustic and miserable aspect of the houscs, is in common to this with the other parts of the country.

This place must not be confounded with a large village, of which the very similar name of Trmieth might occasion some mistake. But this last, in the neighbourhood of which there is a canal, is dependant on the Kiaschefick of Fizim, and about five hours journey from Faïum itsclf.

Between Sinut and Tomieh we met with Aboutigé, a nother considerable market-town. Fragments of ancient edifices and rubbish mark here the site of. the ancient city of Aloms. But all is degraded, all is destroyed. There are here no monuments, no remarkable fragments in preservation, every thing here is broken down and laid in heaps.

We experienced many difficulties in finding a place of abode at Tomieh, and î was only by having recourse to the authority of the Kiaschef that I was able to obtain a shelter for the night. They shew in the mosque a camel of stone; you sce it turn itself towards Mecen, at the instant when the caravan of the pilgrims departs from Cairo, and turn again towards Cairo when it leaves Mecca. Such is the fable which the inhabitants of Tomieh relate, 
relate, and which gives celcbrity to their town. I had it not in my power to examine this miraculous figure.

We departed from Tomieh the 24 th, at six o'clock in the morning. We had hardly proceeded two leagues, when four men on horseback advanced towards us. A peasant gave us to understand that these were robbers; they had in reality the physiognomy and the whole exterior of real highwaymen. They followed us for a long time, without speaking a word, and wheeling round and round us. From time to time they retreated, then couching their lances, they assumed the appearance of bearing upon us with their horses on full gallop. Prepared to bring down the whole four, had they come to the attack, they occasioned us no uncasiness, and we diverted ourselves with observing their manœuvres. Perceiving at last, that, so far from inspiring us with terror, we did nothing but laugh, they quitted us, and disappeared with the rapidity of the wind.

At ten in the morning we arrived at Tahta, a market-town, nearly twclve lcagues from Siout. The Kinschef, who commanded there, was then encamped without the village. He was preparing to march against the Arabs, who refused to pay the accustomed tribute. We stopped to rest our- 
selves for a moment, with the intention of resuming our route immediately, but a Copht, stcivard and secretary to the Kiaschef, and who possessed great riches, begiged me to come and see him; he was ill. I thought that I might have got off on prescribing some remedies to him, but he insisted that I should remain near him, till his cure was perfectly completed. It was in vain for me to urge as a pretcxt for hurrying my departure, that the prince of the Arabs, Ismain Abou Ali, expected my arrival; he assured me, that being very well known to that prince, he would write to inform him that he was the cause of the retardation of my journey. I earnestly entreated him not to do this, for the Arab Ismizn was perfectly ignorant of my existence. I thought that interest would more nearly affect the Copht, the men of that nation being degraded by a sordid spirit, and the love of money, the miserable effects of a long state of slavery; I represented to him that having rather a numerous train, the residence of such a crowd of strangers in his house could not fail to occasion him great expense and inconvenience. I received from this brute a reply worthy of an insolent upstart: "Dost thou think," said he to me, "that Orientalists possess no more "magnanimity and generosity than you Francs, to "whom the expense of one person more is a heary "burden? Were there a thousand of you, I could, "without being incommoded, lodge and entertain 
"you." I had then no choice left but to take up my abode with Mallium Mourcous; this was the name of my patient.

His complaint appeared to me to be very serious; it was an exccedingly violent erysipelas, a kind of St. Anthony's fire, which covered entirely one side of his breast. This part of the trunk appeared as if it were burnt; and the patient felt the same pain from it as if fire had been applied to it perpetually. He could not suffer any clothing or the slightest covering of linen to approach it; and if his shirt, although very fine, happened to touch the parts affected, he uttered loud outcries. This very acute distemper had already tormented him for some time. The Italian missionaries of Echmimm had been called in as physicians: they had bled him, bled him a second time, and still continued to bleed him. The disorder had not abated, and they had given up the case as lost. I was, I will not say more skilful, but more fortunate, and at the end of ton days Malliim Mourcous was perfectly cured.

He did not know how to express his joy and gratitude. The most delicate attentions were lavished on me all the time that I remained with him. The day before my departure, he sent to me by another Copht some rouleaus of chequins. I called 
to mind the tonc of arrogance with which $I$ had been received. I assumed in my turn the accent of haughtiness, and returning the gold into the hands of him who brought it, I ordered him to tell the master of the houre, that a Frenchman rendered his scrvices solely from the pleasure of being useful; but that be would never submit to live at the expense of another; that of consequence I re. quested him to present to Mallium Monurcous a very fine telescope, as a mark of my gratitude for the reception I had met with. The gift was accepted, and I quitted the Copht impressed with a more just opinion of Europeans than he seemed to have entertained at my arrival.

In the number of Cophts, inhabitants of Tahta, several were Catholics; it is well known that the Cophts compose one of those sects which the Roman church condemns as heretical. I frequently risited the most respectable among them, and it was with pleasure that I met there, their cure, an Egyptian who had passed fifteen years in a seminary at Rome. He spoke Latin and Italian very well, and I took delight in conversing with a man whom I regarded as an European. He informed me that the Egyptians attached to the Latin church were cruelly opposed and persecuted by those of their numerous compatriots who followed the keresy with which they were infected, and that their most vio- 
lent and implacable persecutor was the very man with whom I resicled. Possessing the confidence of the Kiaschefs, he arrogated to himself the authority of making exactions upon those of his nation who had adopted a religious persuasion preached by strangers; and frequently these last were obliged to collect considerable sums, in order to prevent the effects of his animosity. Besides, all those Catholics, at least most of them, were poor and wretched; they lived in a state of misery and depression. Not a Bey, not a Kiaschef, not one Mahometan in office, being able to do without the assistance of the Cophts in the management of their affairs or in the excrcise of their employments, reposed any confidence in them, or employed their services if they could help it. Whilst they promised them happiness after death, they rendered them very miserable during their lifetime; and philosophy knows wcll how to appreciate the nature of the services which they receive from our monks.

The curé procured me several little antique stones, the engravings of which had some merit. It was more easy to collect these works of antiquity in Upper Egypt than in the lower part, where the travellers who daily frequent it have rendered them very scarce. It is after the heavy rains of winter in the north of Egypt, and after the inundation of the Nile in the south, that the Egyptians 
more commonly discover engraved stones, as well as medals. All the world knows that roud inedals are very rare in Egypt, whereas you meet there with excellent engraved stones.

You cat at this season, at Tahta, apples which are small and of a very bad quality; they are called in Arabic, tefla. You sce there also a prodigious number of melons of that species known in Egypt under the name of agour ${ }^{*}$.

It is in the plains of Takta that the first specimens of the species of palm-tree called fan-palm made their appearance, peculiar to the upper part of Egypt. It is there called doum and doum saïdi $\uparrow$. This palm-tree, very common in Thehais, shoots forth several stalks naked and of a middling thickness. Circular rings deeply mark them all their length, and broad leaves in the form of a fan terminate and adorn their summit. The fruits, like those of other palm-trees, grow in clusters or bunches. Several of these trees produce a beautiful effect. By disposing their stalks in the form of elegant vases, nature seems to have taken pleasure in enlivening, with the verciure of these magnificent bouquets, plains frequently stript naked, and alwais scorched by the sun.

* Cucumis foliis palmato sinuatis, pomis globosis echinatis.... Cucumis angur:a. Lin. + Borassus Pabelli formis. Lin. 
It is easy to perceive that this species of paln. tree has no other resemblance to the date than the general characters which constitute their genus; and that it differs from it in great and numerous specific dissimilitudes. It is without reason then that the Jesuit Siccard has asserted that the doums are a kind of wild date-trees*; and this observation is not foreign to the subject, for I have heard the same crror repeated by several persons, otherwise very well informed.

Another mistake propagated respecting the doum is this: it has been pretended that the kind of resinous gum, imported from A frica and the Indies under the name of bdellium, and which is nothing else than the common and imperfect myrrh, distilled from its stalks. It is a certain fact, however, that they extract from the palm-tree of Thebaïs neither gum nor any other sort of analogous substance.

The doum produces fruits twice a year. They are round and rather longish; their size is that of an orange, but their form is irregular. They are one of the means of subsistence to the miserable part of the people of Upper Egypt. They take off

* Mem. of Missions to the Levant, vol. v. p. 222. Gran. ger has also confounded the doum with the wild date-tree.[Travels in Egypt, p. 240.] 
the first envelope which is red, and they eat the spungy and almost dry substance with which the nut is covered. Although the Egyptians think this a very savoury fruit, I found it very insipid. I cannot give it another resemblance than to bad gingerbread, of which it has the dryness, and the faint and disagrecable sweetness. I have eaten a fruit in America the taste of which has a great resemblance to this, and which is produced by the courbaril, a very large tree in the southern countrics of the new continent $*$. The pithy substance of the domm is also a medicine made use of in Thebais. They infuse it in watcr with dates; and this draught, which is a cooling and gentle purge, is of great service in tempering the ardour of a fever and in curing it.

I found again in the same place a disgusting and horrible malady, of which I have seen negroes in the French colony of Guiana, become the most wretched victims: it is known there under the denomination of the red disease. An Egyptian who was attacked with it, presented himself to me to be cured. He had lost the greater part of the joints of his hands and his feet, which had fallen off one after the other. The commencement of this species of leprosy which the Arabs call madsjourdam, announces itself by the numbness, the red-

* Himencea courbaril. Lin. 
ness and sweling of the fingers, and by the redness and șivelling of the ears. This is the leprosy of the joints described by Hillary *.

Whatever may be the nature of this leprosy, it does not pass in Egypt for an infectious disorder; it is nevertheless very prudent to have no communication with those who are infected with it. Lepers of every kind, who, without being common, are not very scarce there, are not sequestered from society as in Turkey. The Egyptians do not observe any precaution to kcep themselves from contagion. They never imagine that they are in any danger from this carelessness.

The leper at Tahto was a gentleman quite at his case; he lived according to custom, with his family and his friends, and ate at the same table. The joints which remained on his fingers, and the greater part of which were reacy to fall off, served him to scize in the dishes, in flie same manner as the others with their entire fingers, the pieces of meat which he carried to his mouth in order to go back for more. It was not till after I had advised them to it that his friends resolved to break off so close a communication with a companion so disgusting.

* William Hillary's Observations on the Changes of the Air, and the concomitant epidemic Diseases in the Island of Barbadoes.-London, 1759 .

Furthermore, 
Furthermore, this same man was threescore years old. He had a good appetite, he slest well, and his physiognomy indicated the most perfect health. He suffered no pain whatever. He felt only very violent itchings in the joints of the fingers of his hands, and in his toes, when they began to ulcerate. No person of his family had been attacked with this disease, and he himself had not obscrved the symptoms till about three or four years before. His condition did rot give him any uneasiness; notwithstanding his age and his disorder, he still preserved a great deal of vivacity, and a fund of sprightliness. When I announced to him that his cure was beyond the reach of iny skill, he did not appear affected; and as if I had been giving him the best news possible, he cricd in a joyous tone, Allah Kerim, God is great!

Different observations have demonstrated that men attacked with the leprosy are violently disposed to the physical pleasures of love. An example is cited of a leper, who, on the very night of his death, was hurried away several times by the heat of his temperament. I have seen at Caneus, in the isle of Candia, lepers in great numbers, men and women, banished without the gates of the city in miserable cottages, who abandoned themselves to the utmost excesses of a voluptuous irritation. They were tobe seen sometimes taking their disgusting 
and impetuous pleasures in the face of day, along the road side which conducted to the city, and near which they had their dwellings. The leprosy which consumed them, is the leprosy properly so called, which the Greeks denominate lepra, the same kind with which the Jews were infected, and which was very common and at the same time contagious among them. This was also, according to Galen, an epidemical distemper at Alcxandria.

Curious to know if the sick man of Takta, although attacked with a leprosy of a different nature, felt the same voluptuous transports with the lepers of the isle of Candia, and of several other countries in Turkey, I put some particular questions to him. He recounted to me with the ut most simplicity, the most secret particulars of his domestic economy. His advanced age had not in the least degree weakened his constilution. Burning with continual desires, there was not a day passed in which his wife did not feel more than one effect from it. Even whilst he was speakir g to mec on the subject, his countenance assumed an expression, his eyes brightened in such a manner, as to leave me no doubts respecting what he had said to me. But, and this is an important observation, his wife, notwithstanding an habitual and intimate communication, did not experience one symptom 
of the malady, and felt no inconvenience whatever from it. Three children, the produce of their union, enjoyed equally the most perfect health. This fact was confirmed to me by all those who had a more particular acquaintance with the family of this man.

However, the leprosy of the joints, the red disease of the colonies of America, is regarded there as a very contagious malady, and they carefuliy separate from society all those who are infected with it. Brought by the negroes of the coast of Guinea, it extends its ravages there to the negrocs of the other parts of Africa, as it does to those who are born in America, and even to Europeans who cohabit with black women. The small degree of malignity which a disease, cruel in other climates, retains in Egypt, is then a favourable exception for that of this country already privileged in other respects. It even appears, that this influence of the atmosphere does not confine itself to Egypt alone, and that it extends to other countries of the-East. Indeed M. Niebuhr has remarked that at Bombay, where the leprosy is not rareamong the commonalty of the Indians, it cannot be nualignant, for they allow, without difficulty, those who are diseased with it, to work with those who are in good health *

* Description of Arabia, page 323. 
Whilst I am on the subject of one of the most horrible maladies with which humanity can be afflicted, and that I may no more return to it, I will add, that I had occasion to see besides, in Thebaï, two persons caten up by another specics of leprosy, which I have since met with in the isle of Scio, where it is more common than the ordinary leprosy, that of the Jews, and which the Greeks call lowia. Those who are attacked with it have a hoarse voice; they are tormented with a cough, their eyebrows disappear; large fleshy blisters display themselves over all the body; the nerves contract, and the hands and feet shrink in an extraordinary manner, but the joints of the fingers do not fall off as in the leprosy of the joints. It is probable that this species of leprosy is that which Hillary has distinguished under the denomination of the leprosy of the Arabs*. It is not uncommon in the East ; but is not considcred, like the first sort, as very contagious. I obscrved at Scio, that they did not separate from society the sick persons whom it had attacked.

Thesc same patients are not besides tormented with the same desires as the other lepers with respect to the mechanism of love. It is from not having paid sufficient attention to the different species of leprosies, and to the divers symptoms

* See the work before quoted.

which 
which they exhibit, that people have fallen into contradictions with regard to the temperament of lepcrs. It is certain that those last mentioned had no disposition to lechery. The sufferings occasioned by the violent spasms with which their disease is accompanied, and which cause all the members to contract, deprive them of every species of desire, as well as of all power to gratify it, supposing them capable of the passion; besides, they attain, generally speaking, a very advanced age.

Neither the Egyptians, nor any other of the eastern nations, are acquainted with any preservative against the lcprosy, nor with a remedy to heal it. A Frenchman who gave himself out for a physician, and who rambled over the Levant, pretended to possess a secret, but infallible specific, against this disorder. He visited Caneus, where the number of lepers who exist there offered him a wide field for giving undeniable proofs of the virtue of his precious discovery. But as cxperience did not realize his fine promises, his remedy acquired no greater cclebrity than the other panaceas which this mountebank vended from country to country. I regretted very much that I was not provided with some hemlock pills; it would have been very easy for me to make trial of them, and there is every reason to presume that it would not have been unsuccessful, from the experi- 
ments of M. Ratlaw, physician at Amsterdam, who by the use of those pills, employed likewise with success in the case of excrescences, performed the cure of the elephantiasis of Europe *.

I never heard mentioned, either in Egypt or in the other parts of the Levant which I have traversed, that leprosy which attaches itself to houses, and respecting which there are prescriptions in Leviticus f. Michaëlis is of opinion, that by a metaphor taken from the human leprosy, the Orientalists may have given the same name to certain spots which eat irto the walls, and gradually approach nearer and nearer; he suspects that this disease of the walls must be more common, and more easily perceived in the East, where salt-petre abounds*. These are assuredly very learned conjectures, but they have no foundation in truth. The inhabitants of the East pay indeed no attention whatever to the leprous spots of buildings, admitting that they still make their appearance there. The same people are as little acquainted with another leprosy, which adheres to the garments, and upon the subject of which the Jeivish legislator has recommended such minute precau-

* Michaëlis. Learned and curious Traveilers, \&ic. Scc. Ques, xi.

+ Chap. xir. v. 34, et seq.

¥Work already quotes, ques, xii.

tions. 
tions*. Those diseases of inanimate things, which served only to form the Jews to habits of cleanliness, have disappeared from the East with the dirty people for whom they were devised.

Men with red hair and heards are als uncommon in the Levant as in Egypt. But this colour is not an indication of leprosy, nor a reason to excite suspicion of it, as some persons have imagined $\psi$. It is not in the Levant, nor more particularly in Egypt, they observe such precautions; since, in the last of these countries, the lepers, whatever may be the nature of their malady, are never sequestrated; and that in the Levant they never dream of sending them away, and of shutting them up in enclosures without the cities, till the moment when the leprosy is acknowledged, and when it is evident to every beholder. On the other hand, some Arabs of Egypt dye their beards of a reddish colour, with the powder of henna, and you can very well imagine that, if the idea of the Jeprosy was inseparable from a beard of a red hue, they would not wish to excite a belief that they; were attacked with a malady so repelling.

They know but little of the Arabs and the Egyptians, who imagine, like Michaëlis, after the opi-

* Lev. chap. xiii. v. 4i, et seq.

+ Work already quoted, ques. xxviii.

nion 
nion of a German physician, that in order to remove the suspicion of leprosy, they rendered that colour universal which could give birth to it. Carroty people, adds he, must have introduced this fashion, by bieing the first to paint themselves with kenna to disguise their redness. It is thus that patches employed at first to conceal pimples, are by degrees become a part of dress. I am inclined to believe that this is the real solution of the difficulty *. All these reasonings accumulated in the closet, must fall to the ground, when opposed to facts. Egypt is not the country of fashions, frivolity does not there dictate every day, new customs, and continual alterations in dress. There, habiliments and manners remain as they have been for ages past. Their variation, which is a proof of instability of character, does not compose a feature in that of the inhabitants of Egypt. Besides, the practice of reddening the beard with hema is very far from being universal. I never saw but two or three Arabian princes who made use of it. To conclude, how could red-haired people have any occasion to dye themselves red in order to disguise their colour?

* Work already quoted. Ques. xxviii. 
Southaje-Italian monks of the Socicty de Propacandâ Fite their incivility, their mode of life, their houst - Letle' of their superior-Catholic Cophts - Eriminm -.-Paropolis - Catholic priest - Anique figure-Nosque-Plains of EchminmMetoris-Courtesans-Chrysomal.

3.thy Thata on the rst of June, in the mornins, e continued to travel southwards, on the Wrsiern shore of the Nile, the course of which above Tahta winds in great sinuosities. Wearied of following the heary and slow pace of the camcls, and on the assurances which had been given me of the safety of the roads, I went on before with two of my attendants. After some time had clapsed, I stopped to wait for my other companions, but they did not make their appearance. After having passed the greatest part of this day, which was excessively hot, in looking for them in vain, I went on to Souhajé, well convinced that the rest of my retinue had been attacked and stripped by some band of robbers, perhaps by those who before our arrrival at Tahto had obscrved and hovered about us for some time. 
Southajé, at seven leagues distance from Tahta, is a large village, built at nearly a quarter of a league from the brink of the rivcr. Above, a large canal receives the waters of the Nile, in order to convey it into the plains to the westward. The Kiaschef of Sonthijé requested me to sup and to sleep at his house. His politeness did not quict the uneasiness with which the idea of the loss of my companions and of my baggage, in a country where I had no resource to hope for, cruelly tormented me.

The next morning, before daybreak, I went out in order to cross the Nile, and to go to Echmimm, which is on the eastern shore. I learnt from the master of the passage-boat, that my companions and their camels had arrived there the day before, at a very early hour. The camel-drivers had carried them forward by another route, shorter than that which I had taken, and lengthened out, by penetrating too far into the land.

On my arrival at Ecimimm, a city built at a full half league from the Nilc, I hastened immediately to the convent of Italian monks for the propagation of the faith, where my companions knew we were to go. I found them, in their turn, very uneasy on my account, and just on the point of recrossing the river in search of me. They gave me 
an account of the reception which the monks had given them; it could not have been more unkind, or more uncivil. It was not till after making a great many difficultics that they permitted them to pass the night within the walls of the convent, and it had been intimated to them to provide themselves as well as me with another lodging.

The reception which I met with was not a whit better. When I entered the court, in the middle of which our baggage was thrown down, one of the monks was walking in a gallery; he pretended not to perceive me, and retired into an apartment. 1 ascended, and I saw a young man, a complete monkish doll, whose fair and fresh complexion demonstrated that apostolic zeal did not often expose it to the face of day. A little beard, carefully trimmed, and arranged with uniformity, shaded, without encumbering, his chin ; every thing about him announced the most attentive solicitudes of the toilet, as well as the ton of a petit-maitre. My figure, scorched by the sun, appeared to startle him; the wrinkles of illhumour furrowed his fair forehead, and a look of disdain measured me from top to toe. The pitiful fellow scarcely deigned to raise himself from a sofa, on which he was rather reclined than seated, and allowed me to stand before him; he sold me that my retinue and my baggage had been 
very willingly received, and that they demanded nothing of me for this act of hospitality. Before I made any reply to so much generosity, I presented to him the letter which their superior-general had furnished me with to this convent, and by which he recommended me to the attention of the monks who inhabited it. He read this letter with a smile of contempt, and told me, that not being the superior of the house, he would go and seek for him; after which he returned to his sofa, without either speaking or looking at me again.

The letter of the superior, the composition of a true capuchin, could not, however, have been more precise, nor more urgent. It is as follows:

"Reverendissimo Padre Procuratore excellentissimo "ed amico carissimo.

"Esscndosi a noi presenlato l'honoratissimo " signor Somnini, officiale di marina delle truppe "reggie Francese, et avendoci notificato il suo de"siderio, che é per portarsi in queste parti dell" " superior Egitto, per osservare quelle antichitá ed " insinuarli ove si trovano, e per tal" effetto aven" doci anche parlato l'illustre signor Carlo Maga"lon quivi mercante Francese, nostro carissimo "amico, e ben affetto: per ciò prego le loro I 3 P.I.R.R. 
"P.P. R. R. usarle tutte quelle cortesie, ecarità al " isostra stato, e poverta seraphica, convenevoli, "e possibili, con dirigerlo ancora accio ottenga il "suo intento, et di darle il modo di presentarsi ai " capi degli Arabi, per i quali tiene lettere rac" commandatizic da questi Sanagieck, c cio afin" ché li prestino tutta l'assistenza et li diano tutte " le necessarie guide, \&cc. E tanto sperando dalle "loro imnatc bonta ed attendendone un buon exito, " ai loro commandi sempre pronto, ed arricom"mandandoni alle lori sante orazioni, abbracin"dole di vero cuore, li do la seraphica benedi. " tione e sono di sua procuratione reverendissima "suo umillimo e devotissimo scrvidore, "Fratre Gervasio n'Ermea, Presidente. s Cairo, I2 Marzo, ч778.

"A Rev. Pad. Gedeone di Baviera, "Presidente, Achmin*."

* Translation of this letter.

"To the Right Reverend Falher, Gedeon of Baviera, President at "Achinim.

"M. Sonnini, a naval officer in the French king's service, "having presented himself to us, and having informed us of " his wish to travel into the parts of Upper Egypt, to make ob"servations respecting the antiquities there, M. Charles Maga"lon, a French merchant in this city, our well-beloved friend, " having likew'ise addressed us to the same effect, I entreat you, " $\mathrm{my}$ reverend fathers, that you will observe towards him all "the civility, the willingness to oblige, and the charity, which 
In the apprehension that my patience would be overcome, I quitted the insolent wretch with whom I was, and I descended into the court which we had been permitted to make our parlour. I sent to seck for a lodging in the city, and as the search was tedious, I remained waiting the event till the afternoon, without any person troubling himseli about me, and without my seeing either the superior, or any one else belonging to the house. Neriber did they make their appearance, even at the moment when my goods were put upon the backs of the camels. I left this place without sceing any one of the monks; only I sent them a pataca, as payment of the night's lodging which my companions had had in their house; but they durst not

"your situation and seraphic poverty enable you to put in " practice; togive him directions, likewise, with regard to the " manner in which he may accomplish his designs; to furnish " him with the means of presenting himself to the chief of the "Arabs, for whom he has letters of recommendation from "Sanagiacks, in order that he may receive from him every pos" sible assistance, and that he may supply him vith all the "guides for whom he may have occasion, \&c. \&c.

"Hoping all this from your natural benevolence, and ex. " pecting a favourable issue, I am always at your commands; "I recommend myself to your holy prayers, I embrace you "with all my heart, I give you my seraphic benediction, and "I am of your reverence the most humble and devoted ser. "vant,

" Brother Gervalse d'Ermea, President. "Cairo, I2:h March 1778." 
carry their rudeness to such a lcngth as to accepe of it, and they ordered it to be returned to me.

If we compare the reception I met with from these pretended missionaries, with that which I daily experienced from the Arabs, the Mamelucs, and other inhabitants of Egypt, we shall very soon have the estimate of the hospitality of the one and of the others. The stranger was admitred with frankness, with cordiality, and, at the same time, without any interested view, into the house, or beneath the tent of the half policed man of this country; and he was exposed to the humiliation of being repulsed by Europeans, among whom he might naturally expect to meet with that courtesy which creates friends, the compatriots of those who meet with them in distant lands, whatever might be the part of Europe from whence they at first originated. The day before, an austere Mussulman, whose superstitious pride regards an European as a being almost unworthy to approach him, obliged me to take a place at his table, and in his house; and, the next day, the only Francs who existed in a great city, where they were, like myself, strangers, and tolerated, treated me with the most mortifying incivility.

But these Italian monks, of one of the orders which slothfulness and ignorance characterize, and 
of which the most piously observed regulation is to wallow in abundance at the expense of others, and by the abject means of collecting and begging, degraded by their institution, were extricted for the greatcr part from the lowest and most impure dregs of the pcople.

After all, there were no more than three in the house at Eihmmm. What I beheld of their habitation gave me a grand idea of it; I had not seen any thing so beautiful for a long time. Spacious, and likewise well built, it might have passed for a palace when compared with the houses of the country. The employment of these men, whom Mr. Bruce has represented as being completely destitute of understanding and knowledge $*$, is the same as in Europe, to make dupes, and to amass riches; and it is not to be doubted, that the dread of exposing to the clear-sighted vicw of Europeans, a manner of life which has rendered them contemptible, was one of their principal motives for the ungracious reception which they gave me.

There are a considerable number of Catholic Cophts at Echmimm. I was assured that they formed the half of the population of the city. It is by distributng to them falsehoods and deceptions, that the munks drain them of their money. It was evi-

* Travels to the Sources of the Nile.

dent, 
dent, however, to me, that they were not held in very high estimation among their flocks. One of the must respectable Cophts at Echmimm came to visit me in the house which I occupied; he spoke to me very contemptuonsly of the Franciscans. They had too much money, he told me; it was this which made them disdain to receire me; at another time they would have welcomed me with cagerness. The same Egyptian complained loudly of their avaricious spirit. The poor were neglected by them, and the rich behcld them incessantly at their doors. I was likewisc informed that they made heavy complaints of the English traveller Bruce, who, having made some stay with them, har! not apparently con-sented to satisfy their lore of money, by paying then with heaps of gold for a venal hospitality.

The Catholics had, like those of Tahta, a curé of their nation. He alsoluad passed ten years at Rome, and spoke Italian well, and Latin tolerably. But, less artful than the missionaries, he was in great distrcss. Jealous of his situation, of the confidence with which he inspircd his compatriots, and the practice of physic to which he had applied himself, these cvangelical men tormented him to the utmost of their power; they raised persecutionsagainst him; and faithful observers of serapinir charity, they did not permit a single opportunity of defaming him to escape, and of doing him all the injury they conld. 
If the houses of Eckmimm were of a better construction, this would be a very bcautiful city. The streets are broad and straight. This disposition of streets, without which no city can pretend to be remarkable, is wanting, gencrally speaking, to the other cities of Egypt, for the streets are very narrow, crooked, and badly levelled. But the houses of this place, like those of the other considerable towns in the southern part of Egypt, are built with bricks, not burnt, but simply baked with clay, and dried in the sun. These bricks are cemented with earth. There results from this kind of mason-work a grayish tint spread over all the buildings, and which presents a dull and gloomy appearance. If there were to happen an alteration in the seasons, and were it to rain in these countries, as in the part of Egypt which borders upon the sea, the houses would be seen to melt away, and fall down. Those of persons of note, from their employments or their riches, are more solid, being constructed with bricks half burnt. The walls are adorned with several rows of large earthen pots, of different forms and sizes, which serve as an asylum to pigeons; and almost alt the houses have, besides, their roofs surmounted with a pigconhouse, a sort of square and spacious tower.

$\Lambda$ chain of mountains, of stcep and barren rock, encircles the city to the castward. It reflects the 
to such a degree, as to render it sometimes insupportable. I never felt it so vioient as on the day after my arrival at Echminn; that is to say, the 3 d of the month of June. At four in the afternoon, the mercury in Réaumur's thermometer, placed in the shade, rose to $36^{\circ}$. The wind was to the north-east; but although it blew forcibly, it heated the air instead of cooling it, the sandy plains which it travelled over having caused it to contract an intense heat.

Panopolis and Chemmis are the same city, under two names, of which the one is Greek, the other Egyptian; and the Egyptian name subsists still at this day, in that of Echmimm* Remains of the ancient city are still to be seen to the eastivard, and ncar the cnclosure of the modern town. I observed there an cnormous mass, consisting of a single stone. On one of its sides a Greek inscription was engraved in rude characters. It is almost entirely effaced, and I could not distinguish clearly upon it any thing but the word TIBERIO. A portion of this remarkable stone, and consequently of the inscription, is hidden in the earth. That which appears above it is seventeen feet in length, eight

* Danville. Memoir upon the Difference of Latitudes and Longitudes between Alexandria and Sienna. Memoirs of the Academy of Inscriptions and Belles Lettres, vol, xxix. 
and a half in breadth, and four in thickness. Underneath the uncovered part of this large lump the earth is dug up; this permits you to see perfectly the paintings with which the surface which fronts the ground is covered. You distinguish there, in the midule, a sphere, with the twelve signs of the zodiac. The colour which has best withstood time and devastation, is an azure bluc; the other colours are scarcely perceptible. This stony and white mass is of a calcareous nature; it contains a great quantity of fossile shell-work; it is the same stone with the rocks of the neighbouring mountains; but exposed to the air for such a length of time, it has acquired a hardness which that of the rock has not when first extracted from the quarries.

By the side of this block, you see another less remarkable; this is alinost entirely covered by the earth. The women of this country have formed a cavity in it, which corresponds to a little aqueduct. It is there that by secret and natural irrigations they pretend to procure fecundity.

A little farther off, the ruins of an ancient edifice present themselves to observation; but you can no longer distinguish any thing of the general design; all is overthrown. Immense stones, resembling those which I have just mentioned, dis- 
play still the rematins of hitroglyphes and of paintings.

The cure of the Catholic Copluts had the complaisance to point out to me the curiositics of Echmimm and its cnvirous. On our return from one of thesc excursions, this good man conducted me to his habitation. His apartment was very small, simple but neat; he had collected there several morsels of antiquity, which he regretted he had it not in his power to offer me, having promised a Venetian merchant, of Cairo, to send them him. In truth, he possesscd nothing of very great value. A large number of fragments of emeralds, pierced into amulets, some idols of porcclain, another of alabaster, but completcly worn away, and a figure of wood, of two feet high, composed the whole collection of this respectable Copht, who, whilc I was in his habitation, loaded me with civilities.

Plate XXIX. represents the figure in wood, in the highest preservation, among all those which the Copht had collected. On some places of this figure there were still to be seen the remains of the painting with which it had been covered. It is a player on an instrument, a trumpeter; but the figure is not Egyptian, it has a rclation to the Greck or Roman customs; and there is 


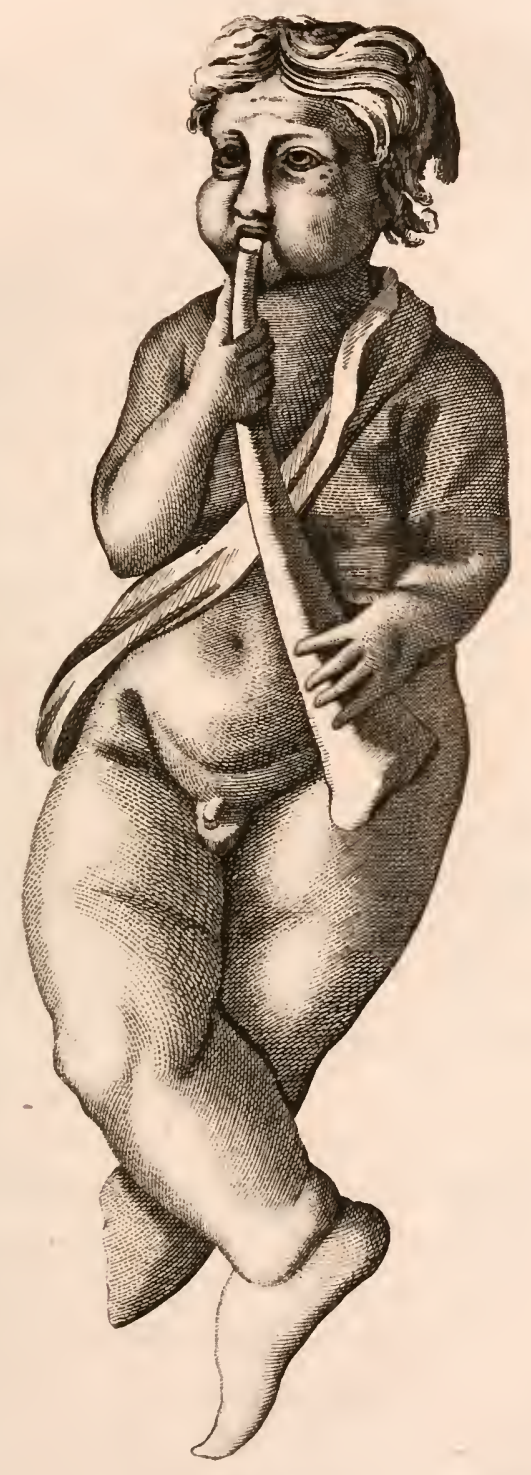

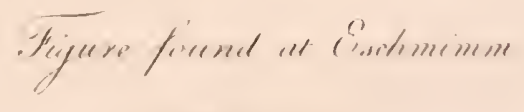

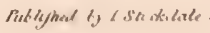



every reason to presume that it owes its origin to that period when the Romans were the inasters of Eggpt.

An ancient mosque is still the object of the reneration of the Christians, who pretend that it was formerly one of their churches. The Cophts allege that it is more than a thousand years old, which is a falsehood. In reality, the edifice, to spcak truth, is falling in every part; but the building, as little durable as that of more moderr houses, sufficiently demonstrates that this is not the workmauship of a period when edifices possessed greater solidity. The temple is spacious; you enter it on several sides; it is enlightened all around by a line of contiguous windows. The interior, resembling that of all the mosques in the same country, is an immense empty and naked cisclosure; but you look with admiration on the small pillars of granite which support it, and which were extracted from the ruins of Panopolis.

The lands cultivated in the cnvirons of Eilmimm are in great reputation for fertility. They produce the finest corn in Egypt, sugar canes, and cotton, which serves for the material of a manufactory of coarse cloths. Gardens, where different species of plants grow under the shade of the fruit-trees, furnish a copious supply for the support of life, and an 
agrecable shelter from the heat of the sun. The date and palm trees of Thebaïs are to be found there in cqually great numbers. The apple-trees produce fruits larger, and not so bad as those of Tahta; but the pastécas are small, and of a very inferior quality to those which I had caten at Siout. The markets are filled will! a prodigious quantity of melons (agour), amongst which some are to be scen of a monstrous size. These fruits do not assume any regular form; some are round, others oval, and some are of a small size, and very much lengthened out like a large cucumber. Finally, the melons of this specics are, generally speaking, of a very bad quality; their pulp is insipid, and not very sweet. It is very rare to meet with such as are even middling, and you never eat any that deserve the epithet good. Nevertheless there is a great consumption of them: the people of Upper Egypt find in these melons a nourishment at a low price, which abates thirst, and the sharpness of the humours produced by the heat of the climate; but the effect of good pastécas is far more certain, and far more agrecable.

The city of Echmimm contains, like all those of Egypt, a crowd of priestesses devoted to the worship of a disgusting voluptucusness: they are accordingly dedicated to the sensuality of the grossest of mankind. The pencil of a magical style has depicted, 
picted, in some celebrated works, the graces and the seductive manourres of these nymphs of pleasure. But however brilliant the colouring with which such a picture may be animated, rigid truth passes the sponge over it and wipes it away.

In reality, although it may be true, as has been said, that in all the places of any note in Egypt there are a considerable number of courtesans, it is false, that, destined to the pleasure of travellers, these last are under an obligation to pay them; that they have been bequeathed to prostitution by charitable men; that the messengers of gallantry conduct the traveller to the temple where the young priestesses so voluntarily take their stations. The panegyric which has been made on their charms, their easy shape, their elegant hips, or the delightful tapering of their waist, in a word, on their desire to please only, and to render you sensible to their attractions, is altogether a series of errors; but what is not less false, is the kind of gencrosity with which an attempt has been made to honour the so little praiseworthy conduct of these girls, by asserting that, contented with being beloved, and preferred to their companions, they will not accept of any thing from the purse of the travcller.

The miserable wretches who are to be seen in the public places of the cities of Egypt, make a rol. III. 
trade, as well as our prostitutes of Europe, of selling the appearance of pleasure. They cndeavour to attract the men, whom they allure to the utmost of their power, extract from them as much as they can, and often strip them with as great address as our courtesans. On the other hand, you will seck in vain among those of Upper Egypt for the ravishing details of beauty which have very unjustly been ascribed to them. You only behold there wretched creatures, ugly, for the most part poorly drest, and repelling, by the excess of their effrontery, so much the more remarkable in these countries, that they are the only women who walk with their faces uncovered, and who speak to men in public; more disgusting still on account of the numberless and frightful diseases with which they are infected; in a word, uniting all the horrors of libertinism without possessing one of its attractions. Such is the real portrait of these women, who cannot have any allurements but in the eyes of brutality. May those young men, who, seduced perhaps by the deceitful picture which has been given of the Egyptian Venuses, may desire an opportunity to pay adoration to them, have no cause of regret. They. would only find in them digusting objects, in comparison with whom the greater part of the courtesans of Europe might pass for divinities. 
In order to do away all the falsc impressions which may have been made from the perusal of forged accounts, I must not omit to say, that associations of women of the town in Egypt, far from being a legal estabiishment, is not so much as tolerated. The commandants of the cities banish all those who have any complaints lodged against them. I have even scen Kiaschefs of a more severe cast; who would not permit one of these miserable creatures to come within the bounds of their jurisdiction.

On my return one day from the gardens of Eclmimm, I found a chrysomal attached to the tuft of my cap. She stuck so closely, that I could not tear it off, but at the expense of its tarsus which remained there. The length of this insect is five lines and a half, and its breadth rather more than two lines. Its eyes are large and elliptical; the upper part of its head is pricked with very small points, as well as the corselet, which is bordered. There is an escutcheon between the sheaths. Rows of little points, among which you see others scattercd irregularly, are between the cases which cover the wings.

The colours of this chrysomal cannot be more rich. The upper part is of a shining green mixed with a dazzling gold colour; underneath, the K 2 golden 
golden green is shaded with brown. The large eyes are globes of the purest gold, the brilliancy of which is still heightened by a black stripe which crosses them in the middle lengthwise. The thighs and the legs are of the same mixed colour with the under part of the body; to conclude, the tarsus and the antenuæ are black.

The Nile, in the neighbourhood of Echmimm, furnishes fish in great abundance. The species which I saw there most commonly, is the bayatte, which grows to a very large size without being much the better*.

Look back to the close of vol. ii. 


\section{CHAP. XLV.}

Italian monks - Cophtish cué- Excessive heatBurdis-Doum-Monks of Farschout-Arabians prince-Furschout-Author's bout put in requisition-Justice which the Arabian prince orderid to be done him-Intolerance on the part of a Mame-

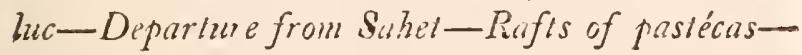
Crocodile-Hou, Diospolis-parva-Kafr Essaiz.n - Rafis of earthenware-Birds-Dogs-Dangerous passage of the Nile-Accident which befell the author's bout-E. Bub, another dangerous place.

B $\mathrm{F}$ ore I quitted Echmimm, I was obliged to have a moment of correspondence with the Italian missiunaries, of whom I had never once thought, and whom I had not seen all the time of my residence. The master of the boat, who had carried me to Siout, had returned to Cairo, from whencc he was to take in a rargo for Upper Egypt. He had promised to bring me whatever might be intrusted to his conveyance for my use, from the country of Francs. We had agreed that the convent of monks at Eichmimm should be the place at which he might find me, or at least gain intelligence respecting me. I wrote then to the superior,

$$
\text { K } 3
$$

thast 
that I expected a piece of service from him which I should be certain of receiving fron the meanest of fellahs, that of sending the reis to Farschout, whither I intended to proceed. I added, that I would not fail to make known in Europe the shameful indignity of his conciuct toward me, and to confirm the bad opinion which Mr. Bruce had already disscminated there respecting their house. My letter was written in Latin; he replied to me in the same language; but in that tone of insipidity, of baseness and perfidy, which is the true characteristic of monks. His reply was conceived in these terms:

\section{"Achmim, die 7mo. Junii.}

"Cum veneril conductor navis, illicò mittam ¿ Farschutum, quia servire suæ illustrissimæ do66 minationi, non servitutem dico, sed honorem. " Gucd autem sua illustrissima dominatio non "fuerit recepta illo honore, qui dehebatur suæ " conditioni, non fuit ex partc mea inurbanitas, "sed casus et error, de quo errore veniam petii " coram interprete illustrissimæ suæ dominiatio" nis; quam, quod impetraverin, sperare me ju" bent sua innata clementia, ct generositas; quòd ¿ autem non adierim in proprâa personâ suam "illustrissimam 
" illustrissiman dominationem, me confusio faciei " meæ prohibebat; interim gratiosis suis favori" bus me perennicè commeudans persisto illustris"simæ dominationis suæ humillimus in Cbristo "servus,

$$
\text { "Er. Josephus a Bayaria*." }
$$

If $I$ had reason to complain of men who are fit for no gool purpose, to whatever part of the world they are transported, and from whom I might, nevertheless, have expected the simple marks of a

\section{* Translation.}

$$
\text { "Achmim, the 7th of Fuly. }
$$

"As soon as the master of the boat arrives here, I will send " him withont delay to Farschout, because to serve your most "illustrious lordship is, I will not say a duty, but an honour. "If your most illustrious lordship was not received with the " honours due to your condition $\dot{\gamma}$, it did not proceed from un. "politeness on my part, but from chance, and a mistake+, "for which I have denanded pardon before the interpreter of " his most illustrious lordship; and his innate goodness, as "well as generosity. will not permit me to doubt that I have ob. " tained it. If I did not come to present myself before your " most illustrious lordship, the confusion with which my coun. "tenance ought to be covered, deprived me of the honour or "the power of doing so. However, recommending myself " earnestly to your favour, I am invariably of your most illus" trious lordship, the very humble servant in Jesus Christ,

"Broiher Joseph of Bavaria."

i I was not received at all.

* It was imposstble for me to comprehend os to imagine a mistake in a thing so clear and so simple. 
civility, which it was not my intention to receive gratis, I cannot suficiently commend the complaisance and attertion of the Cophtish priest, who served as the pastor of the Catholics at Echnimim. He did not fail to visit me ts ice a ciay, and to seek with eagerness every opportunity of beinguseful to me. This contrast of sentiment and of conduct has produced in my soul impressions altogether op. posite; gratitude and friendship for the one, and the most decided contempt for the other.

The honest Copht would not scparate himself from me, or: the day of my departure from $E c h$ mimm, the gth of June, till the moment when I embarked to cruss to the western shore of the Nile, and recommence by land my journey to Farschout. The heat all this day was excessive : the wind was violent, but its impetuosity only serred to fill the atmosphere with clouds of dust, and we were afraid to inhale the impetrous and inflaned blast; men and animals were suffocated, they could not procced without difficulty, and all sought for a shelter from this temperature of fire. Beside, we were, towards the midlle of he day, the only creatures who were travelling, and we did not see a single person on the road we pursued.

We masie the tour of the city of Girge, the capital of Upper Egypt, and arrived at Bardis towards 
wards five in the evening; that is to say, at the moment when the heat, less overwhelmingr, might have rendered the journey more supportable. A Copht of Echmimm had furnished me with a letter to his brother-in-law, a rich inhabitant of Bardis. We were received with very great civility.

The modern town of Bordis, situated at nearly eight leagrues to the sourbward of Echminm, has nothing remarkable in it. Danville places in its environs the ancient city of Ptotemais-Hermii, the largest of Thebais, and of which the particular government had for its model, according to Strabo, the form of the republican governments of Greece. The plains which I had just traversed have the smiling aspect of cultivation and abundance; but when you cast your eyes on the eastern shore, at some distance above Echmimm, you are struck by a truly frirhtful opposition: you see nothing but stcrile mountains, rocks piled upon rocks, the uninhabitable abode of barrenness and horror.

The quantity of palm-irces of Thebaïs is stili greater on the south than to the north of Bardis. The pldins are shaded with them, and they form, with the numerous date-trees, little woods, which enchant the signt. These doums are a productive property of the inhabitants of thosecantors. When I passed that way it was the epocha of the gathering- 
ing-in of the fruits: at the entrance of each vil. lage, large heaps of them were covered with the broad leaves of the palm-tree; and it was to these kind of markets, in the opeu air, that the peoplc resorted to supply themselves with the necessary provision, or to buy them by retail.

I arrived on the afternoon of the Ioth at Farschout, where another colony of Italian monks was planted. I was provided with the same recommendations to them, which had been of so little use to me at Echinimm, and I had a mind to know if they would produce the samc effect at Furschout. I had reason to expect it there, after what I had heard Mir. Bruce say of these monks. They were the same men who had refused him, with great barbarity, on his return from Sennaar, a pound of rice and a morsel of bread. I left my companions, with the cattle, without the city, and I advanced by myself towards the house of the monks. A servant refused to give me admittance, under pretence that the father superior was asleep. I urged him to take charge, at least, of the letter from the superior-general of Cairo; he would not unclertake to deliver it. Wearicd out with so many evasions, I tore the lelter from his hands, and, filled with indignation at an endless repetition of monkish rebuffs, I retired in a rage. I scnt one of the countrymen, who followed me, to inquire for a lodging 
lodging in the city. We continued more than three hours waiting for him, exposed to excessive heat, and the dust scattered through the air ; and finding that he did not return, I sent to request of the monks, by means of my interpreter, that they would at least point out a house to which we might retire. The superior came with the interpreter to entreat that I would accept of his. I did not refuse, because it entered into my plans to pay for the lodging which I might find there; but I must say, to the credit of the monks of Farschout, that they at least displayed to me the exterior of courteous, but perhaps interested hospitality.

There are only two priests in this house; but it could contain a much greater number; for although it is not so vast as that of Eclmimm, it is however spacious, handsome, and commodious. I found there a Christian merchant of Cairo, who bore the same name with the borrowed one under which I disguised my Christianily; he was called Mallium Yousef. I had seen him at Cairo at the house of the Arab prince Dervisch, sovereign of Farschout, and of several cantons to the westward, when he accompanied, with his father-in-law, Ismain Abou Ait, the victorious Mourat Bey. This merchant possessed the conficience of Dervisch, and offered to conduct me to him. 
The next day I went with Mallium Yousef to the house of the prince, which was very inferior to that of the pretended mindicants. He recollected me immediately, as having asked of him at Cairo some assistance toward the journey which I was on the point of undertaking. He received ne very politely, and made me the most gracious offers. But he counsclled me, like all thuse with whom I held any colsursation, to cmirark on the Nile, and to abandon the mode of travelling by land, which I had adopted, because the roads were infested by highwaymen in great numbers. On withdrawing I gave him to understand that i had some bottles of liquors to present hin with, and that I would send them to him the next day. He called me back, and although he was just on the point of mounting his horse, he begged me not to delay making him a present which flattered him extremely, and he promised me that he would not go out till be had received them.

The Sineich Deroisch was the son of Ammam, a prince of the Arabs, cclebrated in Egypt for his intimacy with Ali Bey. He was young, very fat, and of a figure which displayed goodness and mildness. He had a great relish for scusual pleasures. Women and strong liquers formed his prevailing tastes; he was withal, of all the Arabs, the gentlest and most courteous. 
The little city in which Dervisch exercises his sovereisnty, is badly built, and it has the appearance of wretchedncss. It is situated very far up the country. The Nile is at the distance of two full leagues from it. Between it and the river you find a town called Basjoura, where a Kiaschef resides. The port of these two places is a village, which is named Schet. In all probability, Farschout occupies the place of Aconthus, an aswient city of Egypt, near which there was a consecrated wooa. This was the second city thus called; another of the same name occupied the site of Daschour, a little to the south of Sakkara.

Determined to follow the advice which I received on all hands, I renounced my plan of pursuing by land the course of the Nile, and I made an agreement with the master of a karja to convey me to the domains of Ismain Abon Ali. But as I had been equally forewarned that the navigation of the Nile was very little more secure than the roads, I left with the monks of Farschout a part of my effects; for, higher up, the country was filled with robbers.

I was given to understand, that, notwithstanding my bargain with the reis of the boat, the Kiaschef of Basjoura had seized upon my vessel for his own private use. Authority in the hands of persons unworthy 
unworthy of it, produces the same abuses, leads 10 the same excesses; we see it takes the same course in all the countries which are exposed to its caprice and its fury. The desolating system of requisitions, and particularly of arbitrary arrest, was exercised in Egypt with an artfulness and a blind violence which would have put to shame our most furious revolutionists and our most skilful despoilers.

I flew to Deruisch, in order to snlicit his interposition. I did not find him at home, and went to seek for him in ore of his gardens. He was thercaione, under the foliage of sometufted orangetrees, and on the brink of litele streamlets, which rendered a perfumed shade still cooler. When at the groatest distarce the prince perceived me; he arose immeriately, and stcod upright; when I quitted him lie did the same; and, among the Orientalists, this is the greatest as well as the most uncemmon matk of respect. He immediately sent one of his people to the Kiaschef of Basjoura. His message had all the success which 1 could have expected from it, and the boat was restored to $\mathrm{my}^{\prime}$ disposal. I remained ha!f an hour in conversation with the prince. During my visit he made me eat some delicious grapes, and drink lemonade. At the inoment when! was taking leave of him, he asked of me a handicerchief, some medicines, and 
some Cairo brandy. I sent them all some hours afterwards.

In rcturn for these slight presents, Dervisch gave the necessary orders, that my journey might be accomplished with safety; he furnished me with letters to several Arabian Scheicks of the number of his friends; he insisted that one of his scrvants should accompany me, and commanded provisions of every kind to be carried on board my boat.

On the I $5^{\text {th }}$ of June I left the convent of Farschout. During the four days which I passed there, I had great reason to be satisfied with the civilities and the accommodating disposition of the two missionaries who inhabited it. After having stigmatized those of Echmimm, it gives me pleasure to render justice to the courteous and friendly conduct of those of Farschout, and I could wish that both of them were within reach of hearing this frank declaration of the opposite sentiments with which they inspired mc.

Immediately on my arrival upon the shore of the Nile, I ordercd my goods to be carried on board, and I embarked myself. The boat was just on the point of being pushed off, when a Mamcluc who commanded at Saker under the Kiaschef of Basjoura, made us get on shore, and ordered that our bag- 
gage should likewise be landed. It was in vain for me to oppose with all my might this seizure: the sturdy Mameluc, who was surrounded by several soldiers, would listen to nothing. The boat, he said, was for the service of the Kiaschef, and 110 person ought to dare to divert it from its destination. I displayed to him the letters of the Bcys; he replied, that he laughed at all the Beys who commanded at Cairo whilst he was master at Sahet. Not having it in my power to resist the violence of this man, who, like all those to whom power is ill adapted, believed himself a great personage, I ordered my camcls to be brought to re-convey my baggage to Farschout. During the time that they were occupied in loading them, the Mameluc called my interpreter, and desired him to propose to rne that I should give him a chequin, and that for this consideration he would leave me the boat. I ordered him to be told. that I would not even give him a medina. He reduced his demand to a pataca, the half of which I likewise refused to give; at last he begged me as a favour to make him a present of a quarter of a pataca, about fourteen pence. In order to avoid any longer delays, I paid it to him, and the vile slave received it as the price of an imposition practised upon me, and which he had calculated according to the importance of his government.

A great 
A great part of the day had elapsed; it was impossible for us to depart, and we passed the night in our boat opposite to Sahet. The Kiaschef had been informed of the manner in which his representative had oppressed me. He sent another officer to reprimand him, to oblige him to restore the money which he had extorted, and to make his apologies. In truth, he came at night into my kanja. His air was as humble as it had before been insolent. He assured me that the scene of the morning was the effect of drunkenness. I dismissed him very well contented, for I allowed him to carry off the fourteen pence.

I was not yet freed from difficulties: surrounded with men, greedy, deceitful, and dishonest, the traveller sees them spring up under his feet in these distant cantons. The reis, who till then had been a peaceable spectator, wished also to have his turn. He raised his demand; he played off a thousand quirks, and it was not till a long time after the rising of the sun that we were able to quit the shore of Sahet. The weather was calm; the sailors were obliged to drag the boat along with a rope.

We met with several floats formed of pastécas which were descending the Nile. These fruits are extremely common in Thebais, and to avoid the YOL. III, 
trouble of loading boats with them, they collect them in rafts, which float very well, and of which each pice is destined for food. When these floats or rafts have only to cross the river, they do not make them very large, and a man swims across to the opposite shore dragging them after him. If they have a long voyage to perform, they are made larger and towed along by a boat.

The first crocodile which I saw in Egypt, made its appearance at some distance beyond Salket. He was immoveable in the middle of the river; his head alone was visible above the water. In proportion as you ascend the Nile, these frightful animals become more common. They are formidable to the inhabitants. In some places they are obliged to form, even in the river, an euclosure of stakes and faggots, that the women, in drawing water from it, may not have their legs carried off by the crocodiles.

A little village, opposite to which we stopped, points out under the barbarous name of Hlou, the site of Diospolis, which has been surnamed the little, to distinguish it from the two other Diospolis, which are likewise to be found in Egypt. Hors occupies still the eminence upon which, historians tell us, the ancient city was built. Rubbish, large bricks, stones still larger, the remains of a bas- 
fion, and finally an arcade which forms the en. trance of a subterranean conduit, are the sole traces of the antique labours which subsist there.

From thence we ascended up to Kafr Essaiad, another village of little importance, situated on the eastern shore of the Nile, in one of those intersections left by the mountains of rocks which border that shore, to the cultivation and for the habitation of men. We saw descending a flotilla of rafts formed of earthen-ware, which they were conveying to Cairo.

Several flights of birds passed near us: I distin. guished the plover with an ash-coloured ring round its neck, herons, percnopters, rooks, and kites of the same species with those which by their number, the dull colour of their plumage, and their mournful and plaintive cries, render the situation of the cities of Egypt more gloomy instead of enlivening them. These form themselves into companies on the banks of the river, and remain almost immoveable during a part of the day, without doubt waiting for the fishes of passage. Towards night I saw a flight of wild geese.

I observed that the inhabitants of these higher countrics of Egypt kept a kind of dogs very much resembling the shepherd's dog. Their voice is ex-

L 2 tremely 
tremely weakened, they could with difficulty bark. Such is, as it is well known, the effect produced upon dogs by the influence of very hot climates.

The wind had been contrary to us the whole day. In the evening it became favourable, and we profited by it to continue our voyage. The night being very dark, we stopped at an isle of sand waiting for the rising of the moon.

Below this island, the Nile forms a large sinuosity; the current undermines the western shore, which is steep in this broad angle, and detaches from it enormous masses of marshy earth. The frequent fall of such masses as these renders the passage of this place very dangerous for boats, which run the risk of being sunk by them. We had got clear of it without any accident, although every instant, both before and behind us, several large pieces fell, separated from the shore. I congratulated myself on having escaped a danger, against which we had not to struggle; but we found ourselves exposed anew, and in a very disagrecable manner, owing to the improvidence of the boat's crew.

The reis and the saitors were asleep upon the beach; I had passed haif of the night in watching, and I composed myself to sleep, after giving the watcl 
watch to two of my companions, but they too had sunk into slumber. The kanja, badly fastened against the shore, broke loose, and the current carried it away with the utmost rapidity. We were all asleep; not one of us, not even the boatmen, stretched upon the sand, perceived our manner of sailing down at the mercy of the current. After having floated with the stream for the space of a good league, the boat, hurricd along with violence, struck with a terrible crash against the shore, precisely a little below the place from whence the greatest part of the loosened earth fell down.

Awakened by this furious shock, we were not slow in perceiving the critical situation into which we were thrown. The kanja, repelled by the land, which was cut perpendicularly, and driven towards it again by the violence of the current, turned round in every direction, and dashed against the shore in such a manner as excited an apprehension that it would be broken to pieces. The darkness of the night, the frightful noise which the masses separated from the shore spread far and wide as they fell into a deep water; the bubbling which they excited, the agitation of which communicated itself to the boat, rendered our awakening a very melancholy one. 
There was no time to be lost; I made my companions take the oars, which the darkness prevented us from finding so soon as we could have wished; I sprung to the helm, and, encouraging my new and very inexperienced sailors, we succeeded in making our escape from a repetition of shocks, by which wo must all, at length, have inevitably perished; for scarcely had we gained, after several effurts, the middle of the river, when a piece of hardened mud, of an enormous size, tumbled down at the very spot we had just quitted, and which must, had we been but a few minutes later, have carricd us to the bottom.

We crossed to the opposite shore, where we fastened the boat, as well as we could, waiting till the daylight should discover to us where we were, and enable us to recover our Egytian sailors. But it was not long before we perceived them; not seeing the boat, they had thrown themselves into the river to swim, and had gained the shore in pursuit of it, till they got intelligence respecting our fate. The idea of the dangers to which they had exposed us, was too recent not to procure for them some effects of our resentment; and I could not prevent my companions from belabouring them soundily with the very same oars of which they had been obliged to make so un- 
pleasant an use. The reis, who was a little behind, hearing his boat's company roaring aloud, took to his heels, and it was impossible to catch him. The day appeared, and we set sail, in order to pass once more that perilous spot, wherc the force of the current overthrows the barriers which the land opposes to it on the western side. In front of a little village we saw the master seated on the brink of the river. We landed, in order to make him embark; but still in apprehension of having his share of a correction which he well deserved, he made the best of his way off. I gave orders that he should be pursued, and he was conducted, or rather carried back, to the boat.

We again set sail. A violent wind from the north-east, which blew in impetuous squalls, carried us to Dendera, the evening of the 17 th.

At half a league before Dendera, the bed of the Nile is extremely narrow, and one of its banks is strewed with stones. The Egyptian mariners call this place $E l B a b$, the port. This is one of the most dangerous passes of the navigation of the river, and the inhabitants do not fail to address a pray'er to Heaven before they undertake it. 


\section{CHAP. XLVT.}

Tentyris-Dendera-Emir-Temple of Isis-Description of several extraordinary figures-Trochilus of the ancients-Colours-Egyptian village built upon the ancient temple-Efforts of barbarism to destroy it-Vigilance in the boat-Fruits - Situation of Dendera.

Tentyris, or Tentyra, was formerly a celebrated city of Egypt. It gave its name to the nome Tentyritus, of which it was the capital. Its enclosure was extensive, and its magnificence caused it to be regarded as one of the most considerable cilies. Isis and Venus were honoured with a public worship there, and in this place each of these divinities had a temple. But what rendered it particularly remarkable, was the enmity which the inhabitants of it have sworn to the crocodile, and the continual wars which they waged with those hideous reptiles. The Tentyrite pursued the crocodile into the water, overtook him, sprung on his back, and forced a stick into his mouth, by means of which, as with a bit, he conducted him to the shore, and there put him to death. 
Near the ruins of Tentyris is a large village, which has preserved nothing of the splendour of the ancient city but its name of Dendera, which recalls something of its antique origin. It is built at some distance from the western shore of the Nile, at the extremity of a very fertile plain. The orchards surrounding it, the fruits of which, such as oranges, lemons, pomegranates, grapes, and figs, are exquisite, render it delightful, and procure there a delicious coolness in the midst of countries so scorched. A forest of palm and of fruit trees, of which the ancients bave made mention, exists still in its environs, and supplies the greatest part of the fuel consumed in Egypt.

A prince of the Arabs, with the title of emir, governs Dendera as sovereign, and the country which surrounds it; however, he pays tribute to the beys of Cairo. I presented myself at the mansion of the emir : he was very badly lodged: the people who surrounded him had the worst appearance, and every thing in his house announced, not so much an agreeable simplicity as a wretched penury. The prince was habited in the same manner with his subjects, in a long black frock, and he was distinguished from them only by his turban. But what really distinguished him, was the excellent mind with which he was endowed, and which rendered him far superior to the other powerful 
powcrful men of Egypt. After having delivered to him the letters of the beys, and that of his neighbour the Arab scheick, Dervisch, I met with the most gracious reception.

The emir did not wait till I mentioned to him my desire of visiting the remains of Tentyris; he prevented me, in offering me the means of going thither in safety. He spoke to me of several Eu. ropeans whom he had seen at his house, and I perceived that he spoke of them with pleasure. The absurd opinion generally diffused over Egypt, respecting the motive of the researches of travellers, did not enter into his mode of thinking. The Francs were not, in his eyes, magicians; at the voice, or at the signals of whom the most decply concealcd treasures ascended inmediately from the bowels of the earth. One of the Arabs, who were in waiting, having asked him, in my presence, what we were going to do in their country, and what was our design in examining the ruins: "You know no"thing of the matter," replied he; "you do not " comprehend, then, that the ancestors of the "Francs were the possessors of all our countries, and "that it is from respect for the monuments erected "by their forcfathers that they come in scarch of " their paintings and fragments, as objects which "recall to them their ancient power." An adroit and sensible reply, which was very well calculated 
to do aivay the absurd notions which those barbarians still persevered in with regard to travellers.

Although the emir had offered me a lodging, I preferred my own boat. The day after my visit I saw, on my rising, three beautiful horses, which were waiting on the banks of the Nile to conduct me to the site of Teniyris, which is little more than a quarter of a league from the present village of Dendera, towards the mountains of the west. I had hardly arrived there when the prince himself appeared; he conducted me through every place, pointing out to me those parts of the edifice which travellers had delineated or measured, and the spots which they had dug up. He proposed to me to give orders for the ground to be dug up wherever I desired; but this labour, performed at random and in haste, might have involved me in some quarrel, without being of the slightest utility, and $I$ thanked the prince for his offers. He told me, laughing, that the fellahs having imagined that the Francs had discorered heaps of gold in the ruins, had set themselves also to digging them up, and found themselves hardly repaid for their time and labour.

Finally, this man, the most rational whom I met with in Egypt, remounted his horse, after having pointed out to me every thing that was most cu- 
rious there; but he left with me his son, and a part of his servants, to whom he gave it in charce, not to permit the country pcople to approach, and, above all, to be particularly careful that no person disturbed me in my operations.

I found myself before one of the most beautiful monuments of ancient Egypt, which time, and the fatal genius of destruction, had equally assailed; but which, in part, withstood their strokes and their efforts. In the midst of ruins and rubbish, occupying a vast space of ground, a temple still rears itself cntire, and in high preservation; a testimony of the grandeur and the magnificence of ancient Tentyris. This is one of the most striking edifices on which antiquity has endeavoured to impress the seal of immortality, which the Egyptians have had constantly in view, in the prodigious works which they executed. It was dedicated to Isis, and this tutelary divinity of Egypt was worshipped there under the form of a cat.

The temple is built in the form of an oblong square, and of white stones extracted from the calcareous rocks of which the neighbouring mountains are composed. The front is one hundred and thirty-two feet and some inches in length. In the middle of the cornice, a little below the architrave, is a glove supported by the tails of two fishes.

Enormolss 
feet in

Their

if heads

placed

i square ind the

s. For

han de-

sapitals.

I several

tr hiero-

exterior

and the

ly suffi-

reipal of

c forms,

, and of

, for the

atations,

r monu-

ling part

e first is

hich the

ed; you

observe 


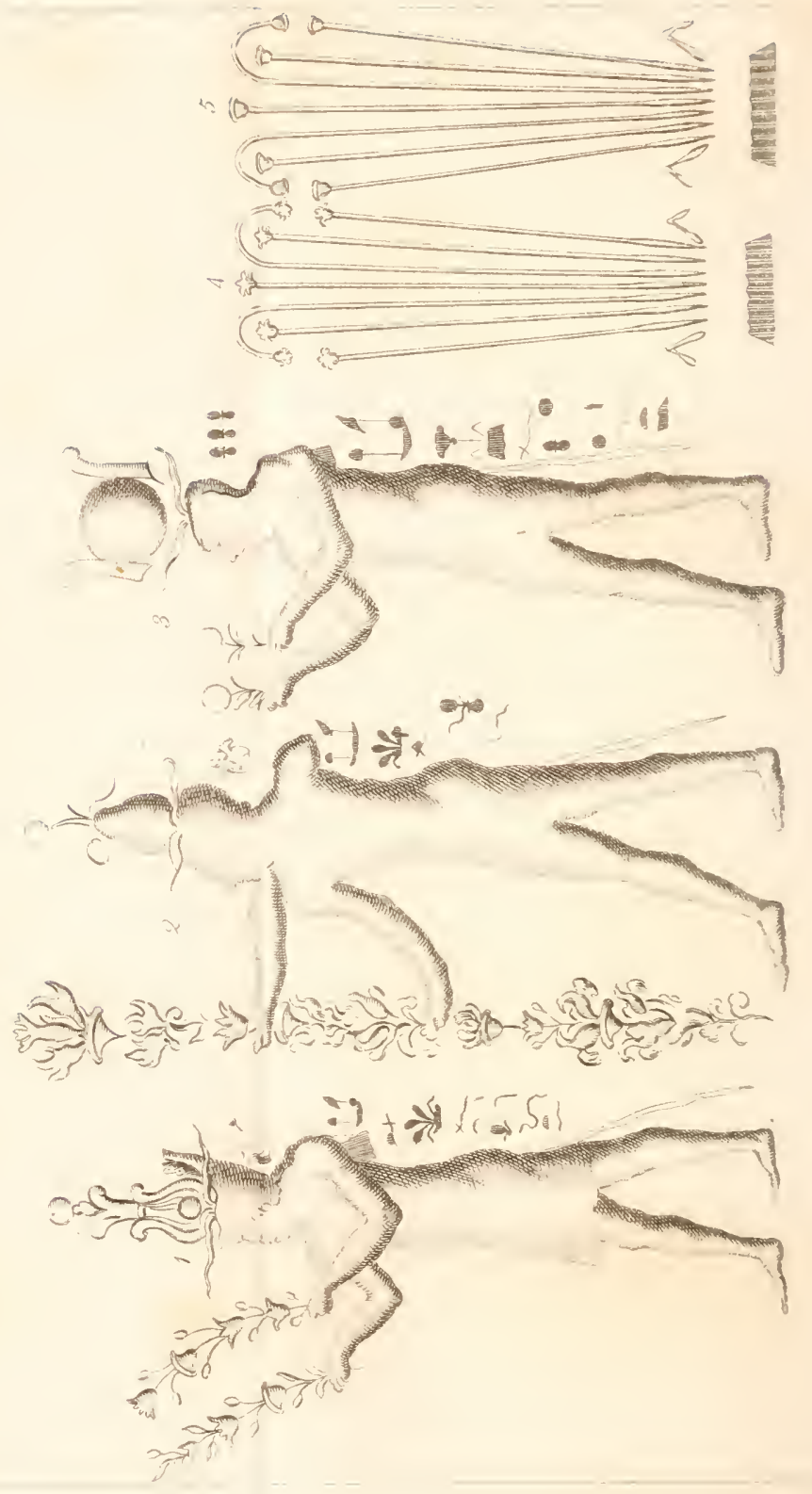


Enormous pillars, which are twenty-one feet in circumference, sustain a large vestibule. Their capitals, of a single piece, represent a sort of heads or broad faces opposed to each other, and placed upon a drapery. They are surmounted by a square block, whose fronts, which project beyond the figures, have some resemblance to pannels. For the rest, plate XXX. will give a clearer idea than descriptions can, of the singular form of these capitals.

The interior of the edifice is divided into several halls, the walls of which are covered with hieroglyphics and symbolical figures. The exterior walls are as completely loaded with them, and the whole life of a designer would be scarcely sufficient to trace a representation of thesc.

I contented myself with having the principal of the figures drawn, of which the ensemble forms, without doubt, the history of the building, and of the time when it was erected. They are, for the greatest part, very extraordinary representations, which are not to be found on any other monuments of ancient Egypt.

You sce, plate XXXI. threc persons forming part of an Isiac procession. The head of the first is crowned with that sort of mitre with which the Egyptian divinities are frequently adorned; you observe 
observe on it the persec and two serpents; ahove the whole is the disk of the moon. In each hand is a bouquet composed of prolific plants. Niy illustrious friend, Citizen Millin, preserver of antiques at the National Museum, and distinguished Professor of Archeology, assured me, that he had never observed any thing resembling this, on any Egyptian monument, but only on an Etruscan vase. What is to be more particularly remarked is, that these prolific flowers produce plants of a nature sometimes different. For example, at the extremity of the stalk supported by the left hand, a flower of one piece produces a flower in several divisions.

The head of the sccond personage in this Isiac procession is dressed somewhat differently, but what he holds in his hand has something still more extraordinary than the branches of the first. This is an Arabesque which has never been seen jet on very ancient monuments, except on those which are called Etruscan. It is well known that these ornaments came from Asia; but you do not find any very ancient specimens of them but on painted vases. Amongst the flowers of this Arabesque therc are birds which appear to be aquatic and palmipedal, and probably geese, which formed a favourite nourishment of the Pharaohs, of the higher classes, and of all those of the sacerdotal order. 


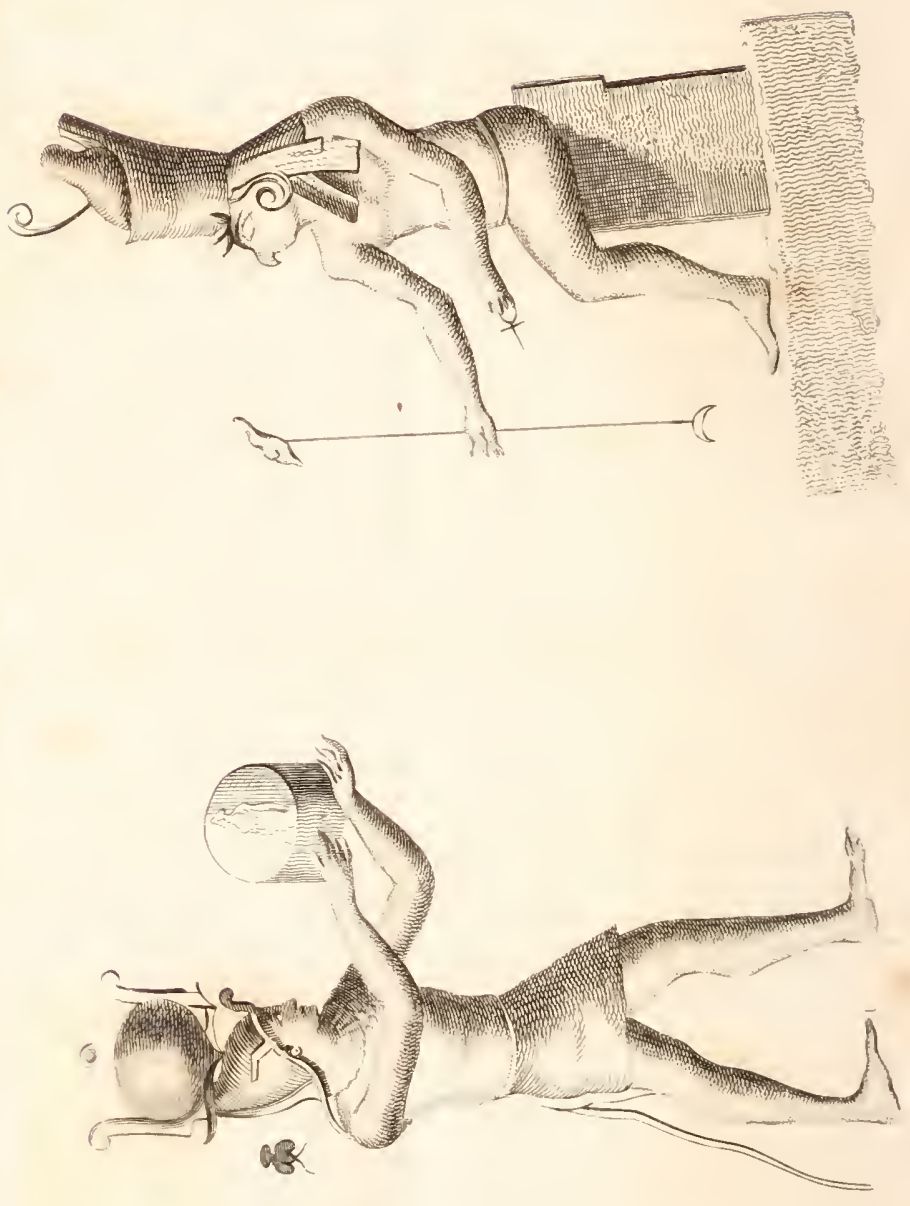
To conclude, figure 3, whose head-dress is still different from that of the two others, bears round fruits, the species of which it is difficult to determinc.

Behind each of these figures is a set of hieroglyphical characters, which, if they could be understood, would give the explanation of the different attributes which distinguished these personages; among these the most astonishing is the long tail which they carry. This peculiarity presents a dif- . ficulty which it is not easy to resolve. All the Egyptian figures, which have tails, are dogs or monkeys; but these have, in reality, the human form, and no one had as yet observed on Egyplian monuments human figures, with an appendage which approximates to that of animals.

The flowers of figure 4 are very probably those of the lotus:, a plant which was celebrated in Egypt as the proof of the so necessary overflowings of the Nile, and as one of the most common means of subsistence to man.

In plate XXXII. the figure seated is that of Osiris with the head of a sparrow-havk. She holds in her left hand the thau, or handled cross, and in her right, a sceptre terminating in the head of a

* Nymphrea lotus. Lin.

lapwing, 
lapwing, and the crescent of the moon. The second figure, with a tail, presenting to Osiris a mutilated cylinder, in which is another small figure, cannot be explained, no other monument having hitherto presented any thing bearing a resemblance to it.

The head-dress of the personage of plateXXXIII. is observable on several figures in the Isiac table. It is probably an Egyptian priest. He holds in his hand a branch of a tree on which a bird is perched. It is not easy to determine to what species of tree the branch belongs. We may believe, with great appearance of truth, that it is the sycamore* which was intended to be represented. This tree, very useful among the Egyptians, is, as has becn seen, that which they employ in making the cases for mummies. The bird having neither the form of the ibis nor of the sparrow-hawk, appears to be the trochilus, equally sacred among the Egyptians. This little bird, the species of which has not yet been exacliy determined, cannot be the wren, as has been imagined, because it is white, and it takes pleasure in the brink of marshes, of lakes, and of rivers $f$. This was, according to the ancients, the only bird which durst approach the crocodile,

* Ficus sycomorus. Lin.

† Marmol, Africa, vol. iii. Plutarch. de Solertia Animalium, page 980 . See the transl. of Herodotus, by Citizen Larcher, book ii. note $23 \mathrm{I}$, on $§ 68$. 


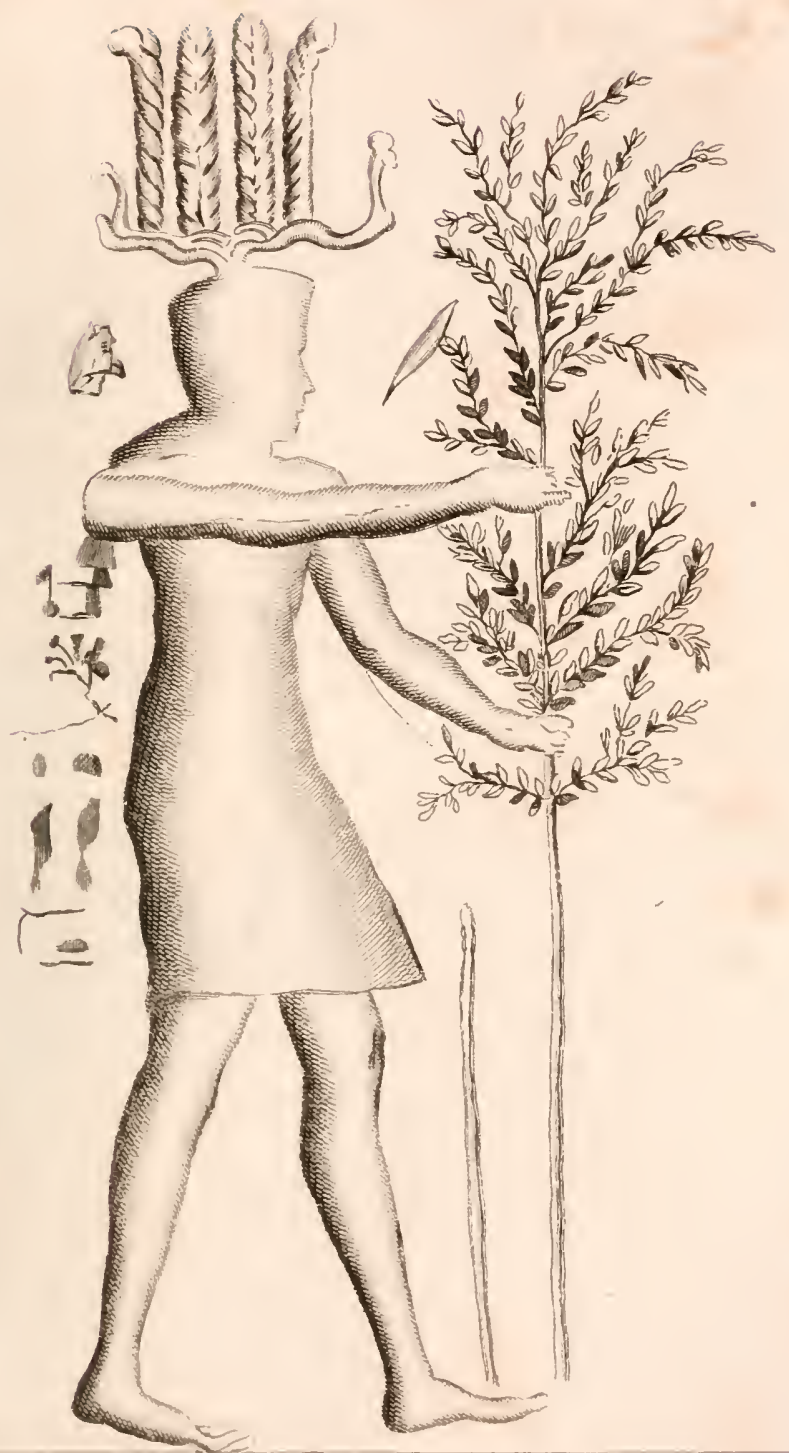

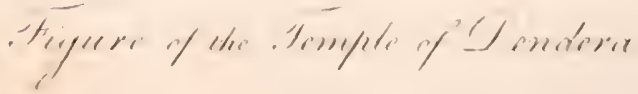




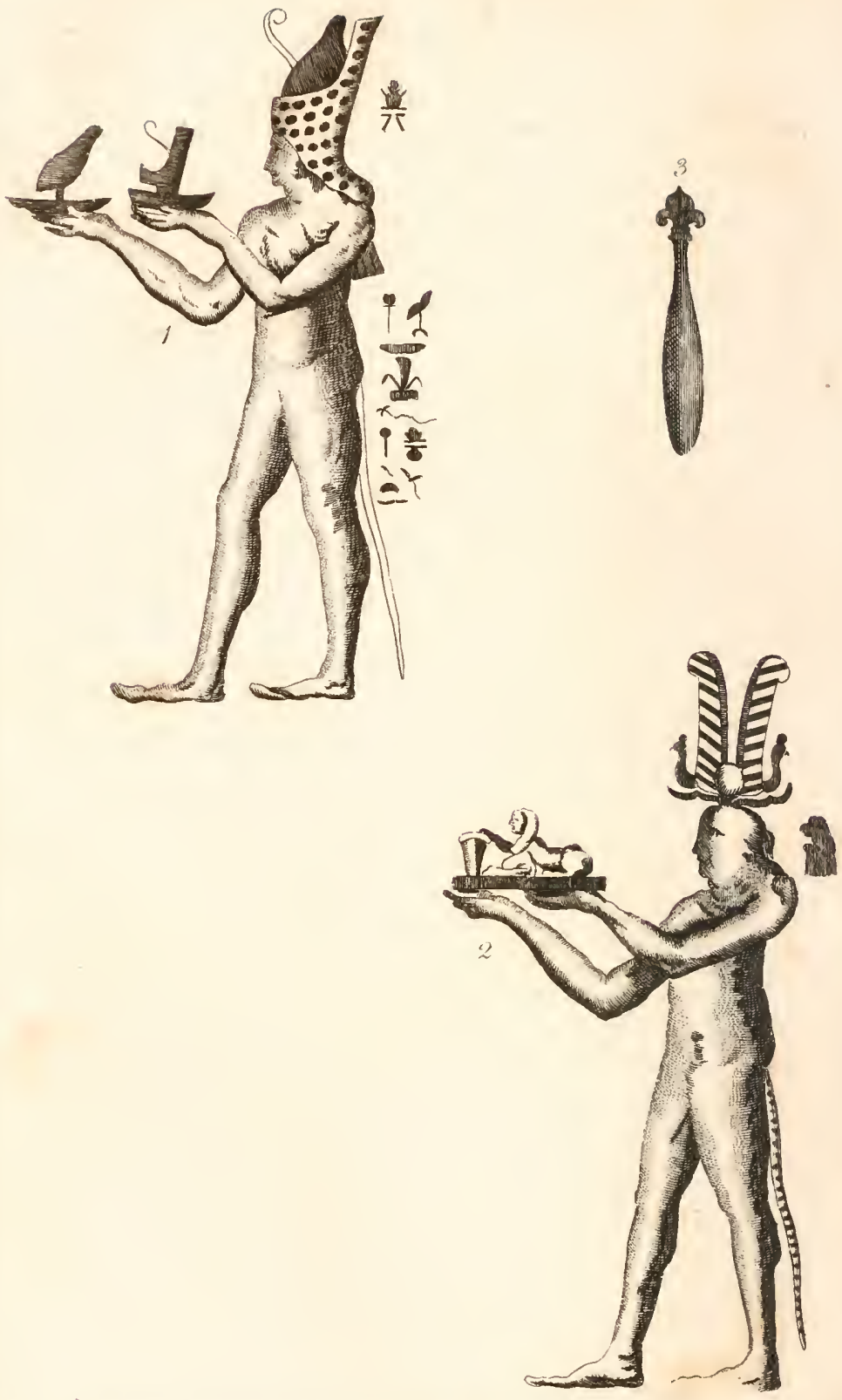

PMazoll Trath

Frigures of the Teimple of Comteree. 

and by which it was beioved, as it rendered him the service of entering his mouth, and eating the leeches which fastened themselves to it*; a custom very different from the nature of the wren, which never eats lecches; and this peculiarity, added to some other probabilites, gives us reason to presume, with some appearance of truth, that the trochilus of the ancients is the kings's-fisher.

You discover again, in plate XXXIV. nearly the same personages as in plate XXXII. The one, that which is seated, is Isis, or Osiris; for it cannot be determined whether it is a man or a woman. As a head-dress it has the disk of the sun, and the crescent of the moon; he holds, in one hand, the cross with a handle, the thau, and in the other a sceptre surmounted with a section of the fruit of the colocasia $\phi$, one of the plants most in use for the food of the Egyptians. This fruit was often placed on the summit of pillars, to serve as a capital in Egyptian architecture. It is unknown who is meant by the person presenting the two vases to the divinity ; it is, to all appearance, a priest.

Two symbolical figures occupy plate XXXV.; but they are inexplicable, till the period come

* See Herodotus on that part quoted in the preceding note; Elian, lib. xii. cap. 15 ; Pliny, Aristotle, \&c. \&c.

+ Arum colocasia. Lin.

VUI. III. 
when we shall be more advanced, that at present, in the knowledge of the hieroglyphics, and the allegorical representations of the aucient Egyptians.

All the figures which I have just mentioned are carved with a chisel, but without skill and without proportion, on the walls, or on the colimus of the anciont temple of Tentyris, and they are five or six feet high. But that which is under number 3 of plate $\mathrm{XXXV}$. is in relief. This composes a part of several others likcivise clevated in relievo, with which the ceiling of the vestibule is ornamented; this is one of the first in front of the vestibule, and to the left as you enter. It is rot possible to imagine that this figure should have been carved posterior to the period at which the others wcre executed. It is confounded with a variety of symbolical representations; the same chisel has hewn them: it is painted of the same colour, the tint of which has the same vividness; in a word, it has, like the rest, the incontestable characters of the same antiquity, and it has, like them, existed in the same edifice during the lapse of thousands of years.

We had but little expectation of finding in a monument of the highest antiquity, and in the heart of Egypt, a sort of sceptre surmounted with 
with the appropriate distinction which the kings of France had adopted for their coat of arms. The fleur-de-lis, such as it has been the emblem of the French monarchy, is well characterized upon the Egyptian figure. In the infinite number of hieroglyphics which I have observed in Egypt, I never met with this baton with a fleurde-lis but once at Dendera. Although projecting, and very apparent, no traveller has paid attention to it; no author has spoken of this Egyptian sign; but however singular it may be, as I have observed it very attentively, and repeatedly, and as it was copied under my inspection, I can attest the reality of its existence at Dendera, and the exact resemblance of figure 3 , in plate $\mathrm{XXXV}$. which represents it.

Furthermore, the fleur-de-lis is very far from having existed, as a coat of arms, co-eval with the origin of the French monarchy; and it is certain that it was not introduced into the arms of France till seven hundred years after its establishment. The most ancient testimony which we have on this subject, is extracted from the memoirs of the chamber of accounts in 1179 . It is observed there that Louis VII. (named the Young) ordered a fleur-de lis to be strewed on the mantle of Philip Augustus his son, when he caused him to be consecrated at Rheims. But if 
the feur-de lis was not very anciently the particular ornament and characteristic of the crown and sceptre of France, it was, in several countries of the East, the mark of power among the nations of antiquity. Herodotus and Strabo relate that the kings of Syria and of Babylon formerly bore the fleur-de-lis at the extremity of their sceptre*. Montfaucon likewise speaks of that of David, found in the miniature of an engraved manuscript of the tentl contury, and which is surmounted by the fletr-de-lis $\psi$ \%. It is evident, therefore, that the ornament called lis (lily) was not a symbol peculiar to the kings of France; and it is not surprising that it composed a part of those which were employed in the mysterious representations of antique Egypt, since it was in former times the mark of power with some sovereigns of this country, or of some adjacent sovereigntics.

A figure not less extraordinary than any of those which I have just mentioned, is that of plate XXXVI. Its position, the length of the arms, equal to that of the thighs and legs taken together, the deformity of all its parts, its head

* Dissert. upon the origin of the Fleurs-de-lis, by M. Rainssant, doctor and professor of medicine at Rheims, 1675 .

t Monum. of the French Monarchy, volo i. prelim. discourse, p. 19. 


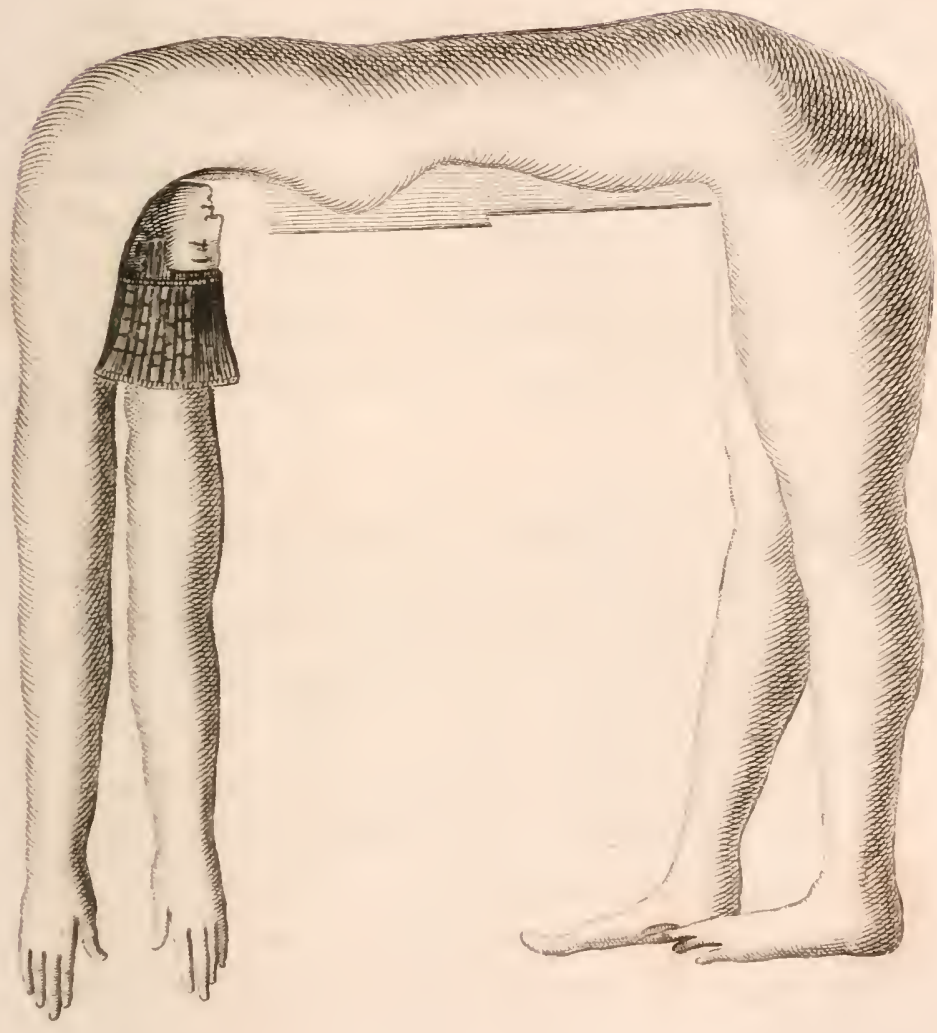

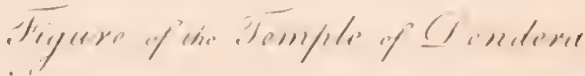



and hands bent downward, its head-dress, are an assemblage of singularities, of which no other Egyptian monument presents the example. You see this figure, truly curious, at the extremity of the temple of Dendera, in a funereal apartment, nearly square, and the sides of which are more than ten feet in length. It is carred in relievo, and occupies the edge of three sides of the ceiling of the apartment of which it would form the cornice, if it were upon the top of the walls, instead of making the round of the ceiling onl $\%$. In the middle are several other smaller figures, likewise in relief, and which the large one encircles.

It was not in their architecture alone that the Egyptians displayed that affection for posterity, that love of immortality, which presides in all their works; they wished also that the painting they employed should be equally durable. The colours of which they made use, the two-edged tool serring to incorporate them closely and for ever with bodies as hard and as solid as stone, are so mary proofs of their profound knowledge in the arts, and so many secrets, which our researches hare not yet been able to discover. The ceiling of the temple of Dendera is painted in fresco, of the brilliant colour of azure blue, with which the vault of the firmament shines in fine weather: the figures in relief strewed along its bottom, are painted of a beautiful yellow : and 
these paintings, at the expiration of some thousands of years, possess still a brilliancy to which our freshest colours do not approach, and they are still as lively as if they had been newly laid on.

I have said that the front of this temple, an admirable, and but little known work of the genius and the patience, which, among the ancient people of Egypt, produced wonders, was an hundred and thirty two feet and some inches in length. I took its other dimensions with the sarre exactness. The depth of the peristyle is an hundred and fifteen feet three inches, and its breadth sixty feet eleven inches. The two sides of the edifice are two hundred and fifty four feet sine inches and a half in length; finally, the depth is a hundred and ten feet eleven inches. The summit of the temple is flattened, and formed of very large stones, which are laid from one pillar to another, or on two walls of separaticu. Several of these masses are eighteen feet long and six broad. Rubbish heaped up, and the sand which collects there, have raised the soil to a !cuel with the roof of the building, and you easily ascend it from behnd, although the front is still elevated seventy feet above ground. The inhabitants of this canton had availed themselves ot this disposition; they had built a village on the very summit of the tomple, as on a basis morc firm than the inconstant sands or marshy 
earth upois which they generally erect their dwellings. When I was at Dendera, this modern village was desolated and overthrown; its ruins of hardened mud formed a singular contrast with the magnificent remaius of the ancient city of Tentyris. We beheld there with sorrow the most complete proof of the total annililation of the arts, in a country which had given birth, and such an astonishing perfection, to them, and the still more deplorable decline of the human mudi.

An establishment of barbarous men could not fail to be fatal to the monument which they profaned by their presence, rather than overloaded it with the weight of their flimsy huts. A number of figures have disappeared under the cfforts of the detestation which they have avowed of the arts in general, and of the representations of animated nature in particular. All those of the figures which were within their reach are cicstroyed. Those of the cciling, and those on the heights of the walls, have been spared, from the impossibility of getting at them. But the fellatis have not been the only people who took delight in mutilating one of the most beautiful and interesting works of antiquity; they were aided in their rage for destruction by the troops of Cairo, who, to serve an usurping and sanguinary bey, often went into Upper Egypt to scarch for, and

$$
\text { II } 4
$$


to combat with a fugitive bey. These ferocious soldiers excresed their barbarity in firing bullets and cannon-shot into several parts of the temple, with the intention of overthrowing it. The beautiful ceiling, the colours of which were still so brilliant, was injured in several places by the impression of those balls, aimed by ignorance and brutaiity; and in this strife of destruction we cannot too much admire the extreme solidity of a building, which had at once to withstand the ravages of time, and the efforts of a stupid ferocity.

The emir, with whom I had frequent conversations, spoke to me with regret of the disorders conmitted by the Mamelucs, when he had the misfortune to see them pass through his little dominion. This prince came one day to pay me a visit in my boat, which served me for a lodging; he was preceded by baskets filled with all sorts of fruits, as very good grapes, delicious figs, apricots (mischisisch) very small and tasteless, pomegranates, the pulp of which is not very savoury, \&c. He gave me also a little engraved stone, and some copper medals, Greek and Roman, of very little value. These medals and engraved stones are very commonly found, as well as other fragments of antiquity, and cmeralds, in the ruins of Tinlyris. To make some return for the 
the courteous and generous behaviour of the emir, I presented him with a fowling-piece, and a small provision of gunpowder; he made great difficulties of accepting my present, but concluded with taking it; and as soon as he returned home he sent me some sheep, and other provisions for my voyage.

The evening before our departure from Dendera, the soth of June, we were obliged to have a sharp look-out in our boat. Some robbers had been strolling about during the night on the banks of the Nile, and they appeared to be preparing to attack us. I was lulled into a profound slumber. All at once I was awakened by frightful outcrics. Our Egyptian sailors, who had apparently perccived the robbers advancing too near, could hit upon no better expedient for our defence, than that of roaring out with all their might. I could not divine the cause of this tumult; and I did not know at first whether the boat was sinking, whether it was consuming by fire, or whether the highwaymen were taking possession of it. Two of my companions were on the watch; but it was a long time before I was able to scttle the countersigns: they $\mathrm{cm}$ ployed themselves in stopping the mouths of the sailors with fisty-cuffs, who had prevented, by their clamours, their scizing two men on the point 
entering the boat. At last a discharge of musketry very soon freed us from a visit too impertinent.

No modern, before Mr. Bruce, had ascertained the situation of Dendera. The astronomical observations which he had the power of making there, have determined the latitude of a place formerly celebrated, and which the beautiful remains of antiquity which it contains render still interesting, at $26^{\circ} 10^{\prime}$. But this traveller reproves, very improperly and sharply, Norden, for having said that Dendera was to the south of Basjoura, a town which Mr. Brucc places at $26^{\circ} 3^{\prime *}$. However, the opinion of Norden is adopted by all those who are acquainted with Upper Egypt: it is conformable to fact, and I cannot conceive how a traveller so well informed as Mr. Bruce should have been mistaken so far, as to place to the north of a point, a place, which in reality is several leagues toward the south, of which it is very easy to be satisfied, by casting your cye over the map of Egypt, plate XXXVII. Some pages further on, Mr. Bruce advances Basjoura $16^{\prime 2}$ more towards the south, by placing it at $26^{\circ} 3^{\prime} 16^{\prime \prime}$. In all this there is apparently some error either in the compilation, or in the translation.

* Travels to the Sources of the Nile. 


\section{CHAP. XLVII.}

Abnoub - Ballas - Earthen pots - Water-metunsNéguadé-Earingquke-The hyena-Wild and domestic animals - The iger-The lion-The hippopolamus-The bear-Boat anchor-RobbersThe slork-The pelican-Ismian-Abou-Ali: description of him; his plan to make himself young again.

Aswoub, a large village which belonged to the A rabian Scheick Ismian-Abou-Ali, is situated about four or five leagues to the south of Dendera, and on the eastern bank of the Nile. It was the beginning of his territories, and he there maintained a commandant. Ballas, another possession of the same prince, which stands three leagues above on the opposite bank, is a trading village, owing to the great quantity of earthen pots which are there manufactured. These vessels have no other name than that of the place where they are made. They are of a iniddling size, and have two handles: the bottom of these pots is externally convex, and nearly terminates in a point, so that they cannot stand upright. This inconvenient shape resembled that of the amphora, or jug, in which the Romans prescrved their wine; it is per- 
petuaicd in Lgypt from the most remote antiquity: for Caylus has given us the figure of a vase in use: amongst the aucient Egyptians, the bottom of which was formed in iike manner*; and Paul Lucas found a similar one amidst the ruins of Dendera $\uparrow$.

In these parts of Upper Egypt you frequently meet with whole districts filied with water-melons. They are sown in the sand on the bank of the river; and it is in this situation, where the burning heat co-operates with the freshness of the water which moistens the stalks, that this fruit acquires its grateful and refreshing pulp; where, under a scorching atmosphere, it is sought after as affording a nourishment equally wholesome and agrecable.

A dead calm having continued during the whole of the $22 \mathrm{~d}$, we could not reach Néguadé, on the west of the Nile, till after mid-day, although we had left Ballas, between which and Néguadé there was only three leagues distance, at daybreak.

It is conferring too much honour on Néguadé to style it, as some havedone, a city; for it scarcely deserves the titlc of a market-town, being in fact nothing else than a village somewhat larger than the rest. It is aimost entirely peopled with Cophts,

\footnotetext{
* Recueil d'Antiquités, pl. I5, No. I.

+ Voyage in 57 t: vol. iii.
} 
among whom there are a few Catholics. They have manufacturers of blue or clouded cloths, which, in a commercial view, are of importance to them, and which diffuse a degree of comfort over the place which they inhabit. A Cophtish bishop resides there, but he does not improve the morals of a crowd of men, who generally, although Christians, are worse than the Mahometans amidst whom they live*. The Catholics have also a curé, who has partly studied at Rome, and two Franciscan friars, stimptuously maintained; and whose seraphic pride looks down with disdain on those whom they are appointed to direct or to convert. These monks, one of whom was a German and the other an Italian, received me tolerably well.

Several shocks of an earthquake were felt during the night, which terrificd the inhabitants of $N \ell^{\prime}-$ guadé. These shocks, as I afterwards learnt, were equally perceptible at Tahta; and in the latter place a meteor was obscrved at the same time, which, by the description given me of it, had some resemblance to a rainbow; it was not so exten. sive, but it had the same form and the same colours. The air was darkened by thick vapours and by the dust which the wind scattered abroad.

* This bishoprick of Néguadé is not included in the list of Cophtish bishopricks given by Forskal (Description of Arabia by Niébuhr, page 79): it has however now existed for some time. 
I was presented by the chief of the mission for the propagation of the faith, with the skin of an hycina *, very large and wel! prescrved. The animal to which it had belonged was killed in the vicinity of Néguadéitself; its Arabian namc is dabba; it is often found in the mountains and woods of Upper Egypt. This animal is not gregarious, like the jackal; it, too, prowls in the night-time, and approaches the habitations of man, like the other animal, but it is gencrally alone, and never in companies. The hycua, fully as carnivorous as the jackal, feeds in like manner on the most disgusting prey; yet bolder, because stronger, it knows better than the other how to attack and carry off living animals. At times it fears not to seize on man himself, and not unfrequently devours children.

Considering Egypt as only that proportion of ground which has been cultivated along the banks of the Nile, and which lies, more or less, enclosed between two chains of mountains, it may be said with sufficient truth, that it contains no species of carnivorous animals. But, although those parched rocks, as well as the scorching and immense plains which border upon them, are uninhabited and uninhabitable, and secm conscquently to belong to no country whatever, it is nevertheless agreed upon to include, under the name of Egypt, that ex* Canis byena. Jitre. 
tent of territory, or rather of sand, comprehended lengthwise between the Red Sea and Libya, the theatre of barrenness and desolation, and the formidable retreat of various savage animals, which sometimes wander from their recesses to infest the plains of which Egypt is in fact composed, because it is in then alone that man can settle.

And if the domestic animals are in this country, as in other adjacent places, the most gentle and tractable in the world, the beasts of prey are also the fiercest of all others. Their rage, like the heat of the climate, is extreme; so true it is, that man alone has been able to change the disposition of the former of these, which would naturally have been as wild as the latter are ferocious; and that it is to long-established and very intimate domestic habits that they owe the good qualities which distinguish them.

The cares of the lofty and rugged mountains which border the Nile on the east and on the west, afford haunts inaccessible, and fit only for voracious animals; it is thither that the fierce hyena drags the victims she has run down, and where she heaps up their bones on an extensive plain of carnage. She is almost the only quadruped of prey which inhabits these dismal solimdes. Those animals, which under a clothing elegantly 
elegantly varicgated, and with a form smooth and slender, have addicted themselves to cruclty and the dreadful thirst for blood, do not often appear there; and the lion, whose speeies is every where decreasing, is also very rarely to be found in the vicinity of Egypt; he is afraid to penetrate there, or, if he attempts it, his stay is of short duration. The Egyptians call him sabbé.

Lions and parti..coloured quadrupeds are not the only animals whose race has diminished successively, andat length entirely disappcared out of the land of Egypt. Thehippopotamus* was anciently very common about that part of the Nile which washes Egypt. "Those," says Herodotus, "which are found in " the district of Papremis are sacred, but in other " parts of Egypt they are not considered in the " same light $\uparrow$ " They laid waste whole countries by ravages as fearful as their size was cnormous, and they were equally formidable to man with the crocodile $*$. From the terror which they inspired, they were gencrally looked upon as the symbol of Typhon, that giant who had spread death and destruction among the deities which were worshipped

* Hippopatamus amphibius. Lin.

† Bonk 2. §7 . Translation of Citizen Larcher.

¥ A species of sea-horse inhabits the Nile, which is fully " as mischievous as the crocodile." Pausanias, translation of Gedoyn, book 4. Voyage into Mysenia, p. 400. 
in that quarter; they were of course the cmblem of mischance and of cruelty.

Among superstitious nations, terror also lyas its deities, and it is to this painful idea alone that we are to ascribe the particular worship with which these clumsy and dangerous quadrupeds were honourred at Papremis, solely in the view of appeasing or averting their rage. But the hippopotamus, as the author of Philosophical Researches respecting the Egyptians and the Chinese, has justly observed, far from approaching, in the present day, as high as Old Cairo, does not even descend below the cataracts of the Nile : after becoming very scarce in Egypt, he has finally disappeared altogether.

It is well known that very few of the race of the hippopotamus have been found in this country during the last two centuries; and the wras in which they were seen have been marked. About the year $155^{\circ}$, Bellonius sav one of those animals at Constantinople, whither it had been brought from Egypt *, supposing however that it really was an hippopotamus, which the traveller examined, in the capital of the Turkish empire; which Mathiolus, supported by some errors in the description,

* Petr. Beiloniii de Aquatil. Parisiis, 1553, page 84 , and Observ. folio 103, verso.

VOL. III. 
disputes with him: "I think," says he, "that "Bellonius saw double, or that he relates more "than he saw*." In I 600 , Frederico Zerenghi, an Italian surgeon, killed two of them near Damietta $\uparrow$. Fifty-cight years afterwards some janisaries shot another on shore, where it had come to feed, near Girgé, the capital of the Scizil: it was brought dead to Cairo, where it was described by Thérenot *. Nearly about the same time, Pietro Della-Valle obscrves, that one was kept alive at Cairo $\$$; perhaps it was the same of which Thévenot makes mention; as those of which Maillet speaks, as having been taken some years before he was appointed consul, in 1692 , are also probably the same which Zerenghi killed \|: so that the last precise date of the appcarance of the hippopotamus in Egypt would be in the year 1658 .

Indeed, since, or about this time, the hippopotamus has no longer made its appearance in Egypt; the name seems also to be lost with the race, for the

* Comment. or Dioscorides, Pinet's transiation, Lyons, 1604 , page 138 , cul. I.

$\dagger$ Hist. Nat. des Quadrupides par Buffon, article de l'Hippopotame.

$\mp$ Voyage to the Levant, by Thévenct, page 491 .

$\S$ "I thave seen in Cairo severai living animals, such as .... "sea-horses." Voyage de Pietro Della-Valle, Paris, 1670 , tom. i. page 3 ro.

II Defc, de l'Egypte par Maillet, part ii. p. 3I. 
inhabitants of the Said, where formerly these animals were most commonly found, know as little of the denomination of River Horse as of the animal himself to which that title is given; they seem even to retain no longer an idea of it. Doctor Shatv has also ascertained the same fact with respect to the people of Lower Egypt *.

It is surprising that the hippopotamus should have so far deserted Egypt as to be at present scarcely known there. This emigration, almost sudden, could not have been occasioned either by an increase of inhabitants, or by their more active industry if ; for no one is ignorant that this country was in former ages much more numerously peopled and infinitely better cultivated than it is in modern times.

In reflecting on the disappearance of the hippopotamus from that part of the Nile which waters Egypt, I only perceive the natural effect of the use of fire-arms, now generally prevalent in this country, for a certain number of years past, although these arms, or at least cannon, were not as yet very

* Travels, French translation.

† Buffon (in his natural history of the lion) has proved, that the lion species is reduced to the tenth part of what it used to be, occasioned, he says, by the increase of the human race. 
numerous at the time of my voyage: but there was not a village of the least siguificance, whose commandant did not possess two or three field-pieces, which were discharged from no motive whatever sereral times every day; and these villages are, it is known, on the brink of rivers and of canals. Armics, or rather bands of Mamelucs, were almost constanily in the field; the river was often covered with fiotillas of their armed boats; and they took with them, upon every occasion, a small train of artillery, which would have been altogether uscless, had they not perpetually played it off for the sole pleasure of making a noise. Such a disturbance, from these frequent explosions, would have been sufficient to frighten away ani. mals which travellers agree in representing, generally speakine, as very timid, and to banish them into $A$ bysinia, where these roaring machines were not known. Happy would the Egyptians have been, had they not had greater ravages to endure from those who frecd them from noxious animals, than they liad eren cause to apprehend from the multiplication of such animals.

It has been said that the hippopotamus could not live long out of the water * that he lived at the botton of rivers, where he waiked at his

* Aristotie, Pliny, Mathiolus, \&c. 
ease*; that he was carried down to the depths of the sea by the weight of his body, and that he only swam at the mouth of rivers t, Eic. \&xc. It has also been affirmed, that he could not long remain in the water. Finally, Forster was assured, at the Cape of Good Hope, that the hippopotamus there could not travel more than thirty yards at a time ${ }^{*}$. It results from all that has been said concerning this animal, that his natural history is not yet well understood. There is every reason to suppose that more enlarged observations will render it clear, that the hippopotamus of the rivers is not the hippopotamus of the sea; that they are two distinct specics; and that it is from not making this distinction, which appears certain, that differences have arisen in the descriptions and accounts given of those quadrupeds. It may even be suspected, with some appearance of probability, that the greater part of sca animals represented by travellers as the hippopotanus, are nothing else than a species of great phocie.

The hippopotamus was not the cinly savage animal held in veneration at P'upremis; the bear

* Bel!onius, in his works before quoted.

+ See a physical and historical dissertation on the pronf of innocence or guilt by immersion, by Pierquin, curé of Lcr. raine, printed in 1731 .

† Second Voyage of Capt. Conk, French trąnslation, voul. j. p.: 34 . 
had also his burying-place there ${ }^{*}$ : but in other parts of Egypt, according to the report of Herodotus, who adds, that this animal is there very scarce, they were buried in the same place where they were found dead $t$. Pliny, however, states that there are no bears in Egypt $\neq$. Laying aside ancient and modern proofs, which appear positive, I stiould be inclined to the opinion of this celebrated and elegant natural historian, and should suppose that traveliers might, at a distance, mistake the hyena for the bear. Indeed, how can we believe that an animal, whose thick fur sufficiently indicates that he is the native of a cold climate, which delights in hilly and thickly-shaded forests, should equally accustom himself to live in waste and sandy plains, which a scorching sun heats and dries up, and in which he could find no means of subsistence? Of the two species of bear which cxist, that of black and of red bears, the former could not live in solitudes, which did not afford him the thickness of forests, nor those fruits, roots, or grains on which these animals subsist. If the latter sort of bear is intended, the red or brown, "which" are found not "only in Savoy, but in lofty mountains, in vast

* Pauw, Philosophical Researches respecting the Egyptians and Chinese, vol. i. p. I52.

+ Book ii. $\$ 6 \%$. Larcher's translation.

$\neq$ Hi.t. Nat. lib. viii. cap. 76 .

"forests, 
"forests, and in almost all the deserts of the " earth, which devour living animals, and even "feed on the vilest garbage*," can it be imagined that the mountains and deserts of Egypt would yield them suitable retreats or nourish. ment?

However powerful an inference deduced from coinciding circumstances may be, when, upon comparing them, the observer is rarely deceived in the consequences which result, and however forcible those proofs in support of Pliny's opinion, which both what $I$ have scen and rear induces me to adopt ; it must nevertheless be admitled, that a great number of authorities leave no doubt as to the existence of bears in Africa.

An acquaintance with the real position of the ancient city of Papremis, where the bear was more honoured than elsewhere, would not do away my doubts, if any remained: for even supposing that it was not remote from the district of Nitria, or the desert of St. Macaria, as Mr. Pauw conjectures, the same difficulty still remains. Indeed, among the many animals which $I$ have net with in this desert, I did not once see the bear. The Bedouins, accustomed to frequent that part of the

* Buffon, Natural History of Quadrupeds, ariciele Brar.

$$
\mathrm{N}_{4} \text { solitudes }
$$


solitudes of Libya, have assured me they never saw that animal; and the Cophtish monks, more dangerous in these abandoned and depopulated regions than the ferocious animals with which they partake a dwelling-place, have confirmed on this head the testimony of the Bedouins.

I only passed the night at Néguacé, and left it on the $23^{d}$ at nine in the morning. Although Lawor was distant no more than from eight to nine leagues, and the wind was favourable, we could not reach it on that day, on account of the frequent windings of the Nile, which prolong its navigation, and at the same time render it difficult. We found ourselves in very dangerous regions, from the great number of robbers, whose only occupation is to strip travellers, and pluncler their boats. We could not think of approaching either batik, and I therefore ordered to cast anchor for the night in the very middle of the river. A large stone serred to hold fast my boat, and a sorry rope made of the rind of the palm-tree, was fastened to it by way of cable. During the night a skilful swinmer approached us, gliding through the water without the slightest noise; we kept a good look-out; he was perceived, and a musketshot soon forced him to decamp with less precalition than he had made use of in advancing toward us. 
The $24^{\text {th }}$, at daybreak, we weighed the block of stone which kept fast our boat, and arrived at Luxor, a village on the eastern bank, built upon the ruins of Thebes. I was there informcd that the Arabian prince, Ismain-Abou-Ali, who was visiting his possessions, was at that time encamped near a small village opposite to Luxor. Fearful that I should not be able to join him, I hastened to cross the river, for the purpose of seeing a man whose power and credit were in so great repute.

For two days past I had met a great number of storks*, and several pelicans $\psi$. The inluabitants of Upper Egypt call this latter bird, chameau d'eau (water camel), from the membranous bag which it has under the bill, and which, when filled, has some resemblance to the leathern bottles containing water with which they load the camel.

Having arrived at the camp, I presented myself before Scheick Ismaïn. He was a litt'e old man, very ugly, and quite infirm. I found him in his tent, wrapped up in a shabby woollen great coat, torn to tatters, and very dirty, which lie half unfolded every iustant to spit upon his clothes. This disgusting man was still foppish enough to dye his beard red with henna, undoubtedly with a view to hide the glaring proofs of his old age. But this

* Ardea ciconia. Lin.

+ Pelicanus onocratulus. Lin.

precaution 
precaution made him look still more hideous, and the fiery colour of the hemu on a wrinkled and faded visage, produced a very disagreeable effect. Yet although his physical appearance was vile and unpleasant, his head was clear, and his mind displayed much viracity. A concourse of Arabians and of the inhabitants cncircled him; he listened to them with attention whilst he was dictating to his secretaries; he issued his orders, and gave his decisions, with surprising distinctness and regard to justice. I remained some time before the open tent of the prince, and, when be had finished the most important affairs, asked, in a tone of voice sufficiently dry, who I was. I approached him, and delivered the leticr of Mourat Bey. As soon as he had read it, he extolled the attention of his friend, who had sent him a physician of extraordinary skill, who was at last to cure him of all his diseases, and they were not few : but that which secmed to affect him the most, and which he soon imparted to me; that which, itself alone, would have discouraged the most skilful doctor, and of which Ismän, nevertheless, flattered himself I should be able to cure him, was his state of weakness and incapacity for enjoyments which he could not resolve to renounce. This task was set before me as of the first importance to accomplish; the rest would follow in the ir course. I was to enter upon my office by renewing the routh of 
this second AEson; and from the manner in which he spoke of it, I perceived that the thing appeared to him as easy and simple as if 1 had possessed the magical arts of a Medea. To lose no time in effecting a cure of such importance, the old Arabian hinted to me that I should accompany him in visiting his estates, and that during our journey he would take the necessary restoratives.

Ismain was also accustomed to chew and smoke haschisch, an intoxicating preparation from the hemp of Egypt, of which I have before given a description. He sunk every day into the gentle torpor, the keif, which that plant superinduces; but habit had given him a desire to change this method, and he instructed me to provide him some other ingredient which should produce a similar effect, always cxcepting wines and other spirituous liquors, to which he had an utter aversion.

After the prince had made me acquainted with his plans, he resumed the course ot his affairs, and I retired to the shade of a grove of trees, in the middle of which his tent :vas situated. I was im mediatcly surrounded by that kind of people who, in Africa as in Europe, follow on the heels of those who appear to be in favour with the great. A sumptuous dinner was served up to me, during which I did not want either lookers-on or flattcrers, 
tercrs, and I had a capital opportunity of playing the great inan. But I was thinking of other things than of the idiots who were teasing me; the injunctions which Ismain had laid upon me never quitted my imagination. I was conscious that I did not possess the gift of miracles, and that was absolutcly necessary to enable me to satisfy him. I determined to abandon a delicate situation which I was not in a condition to fill. After having dined, the prince fell asleep, and I availed mysclf of that circumstance to return to Luxor, where a Cophtish Catholic, whom I had scen at Néguadé, had already entertained me.

On awakening, the prince unfortunately turned his thoughts on me: he cried out with all his might, Fen hakin? Fen hakin? (Where is the physician? Where is the physician?) When he learnt that I was at Luxor, he dispatched a messenger after me to say, that Mourat Bey having sent me to his assistance, I must not think of quitting him, and that from that period I was his physicion. This message concluded with an order to hold myself in readiness the next day, to accom: pany Ismaïn in his journey. Sheep and provisions of every kind followed the messenger, and were presented to me in the name of my illustrious and whimsical pationt. 
I felt myself very much embarrassed; it was necessary to make up my mind; and it would have been imprudent to refuse to gratify the inclinations of Ismaïn. To gain a little time, I replied, that I was ready to follow him, but that as he was to pass by Néguadé in a few days, I entreated him to permit me to go and wait at that place for him, because I should be there more commodiously lodged than elsewhere, having occasion to take some repose. The same messenger returned with Ismaïn's consent, and with a written order on his overseer at Néguadé, to furnish me with every thing necessary or agrecable. I thought it my duty to take the road immediately, and I departed for Néguadé, where I hoped to discover some method of making my escape from the dangerous honour of being physician to the Arabian court. 


\section{CHAP. XLVIII.}

Return 10 Néguade-Swelling of the Nile-Waterspinners-Kous-Remains of the eity of ApolloMokkia coffee-Fertility of the soil in Upper Egypt -Its agriculture-Granivorous birds-Swallows - Laundress - Ravens - Flies - Bugs - Insents still more disgusting-Ichneumon fly-Drone bee -Wasp - Scorpion-Crab-Degeneracy of the people of Egypt-Women of. Thebaïs-Those who have embraced the Catholic faith, Huve become subject to foreign monks-Effects of jealousy in women-Purgatives - Senna-Venereal discases-Mastich.

ONE of the Italian monks of Néguadé was at Luxor; he had come to go his round of begging, and to collect the alms of the Catholics of this canton. His expedition had been a good one, and he loaded my boat with the pious contributions which he had levied. We reached Néguadé the $26 \mathrm{~h}$ June, at nine o'clock in the evening, and my seraplaic guide conducted me to his habitation, where I remained for some days.

We were on the eve of the swelling of the Nile; its waters had changed their colour some days before, 
fore, and had begun to rise. The inhabitants were in hopes that the inundation would this year be considerable; they grounded this expectation on the great number of water-spinners * which as. sembled above the surface of the earth, experience having taught them, that the more abundant these insects are, the more abundant will be the waters of the river. Whole swarms, or, to spcak more properly, clouds of water-spinners were seen so thick, that the air, to a certain height, was filled with them, and you might, if I may so express myself, have cut them with a knife.

The day after my arrival a Cophtisin Catholic of Kous engaged me to meet the Superior whom he had just invited to dinner. On the 28 th we passed the Nile, and found, on landing, horses in readiness to convey us to Kous, which the inhabitants of the Said pronounce Gous. It is a town in which a Kiaschef resided, and which is situated at some distance from the castern bank of the Nile, opposite to Néguadé, but about half a league more to the northward: according to Danville, it now fills the place of the ancient city of Apollinis-parva, which Anthony, in his Itinerary, simply styles vicus Apollimis, or the village of Apollo. The only monument of antiquity to be seen there, was the front of a small temple dedicated to the sun, half buried. Its pian

\section{* Tipula culiciformis.}


is a rectangular parallelogram of the width of thirty fect; the sand and rubbish conceal the greatest part of it, and the remainder does not rise more than ten or twelve feet above ground. Some hieroglyphical figures and characters had been engraved upon the wall, but the superstitious barbarism of the inhabitants, more than the hand of time, had almost entirely effaced them. It was now no longer possible to distinguish any of the Greck inscriptions traced on the frize, and one of which was copicd by Paul Lucas*, and the other by Granger to

I reived many civilities from the Copht, an old man who lived at his ease, and who was highly respected. His name was Mallium Poclor. The repast with which he regaled us was looked upon as sumptuous in this country, and, according to custom, date-brandy was not forgotten.

Cossuir, a port on the Red Sea, is three long day's journey from Kous. The road which leads to it lies across the desert. It is the track the caravans pursue, which transport into Arabia the commodities of Egypt, and which carry thither the coffee of Yemen. The greater nurber of these caravans from Cosseir deliver at Kous. Some also go to Kenné, and others

* Voyage performed in 1714, vol. ii. rage 2.

+ Traveis through Egypt in : $: 30$, page 43. 
to Banoub. If you wish to be supplied with excellent coffee, you must go to one of these three places to find it. When once it arrived at Cairo, or had crossed the Nile, it was no longer pure. Merchants were waiting there to mix it with the common coffee of America. At Alexandria it underwent a second mixture by the factors who forwarded it to Marseilles, where they did not fail again to adulterateit; so that the pretended Mokka coffee, which is used in France, is often the growth of the American colonies, with about a third, and seldom with a half of the genuine coffee of Ycmen. When I was at Kous an hundred weight of this coffee, unadulterated, and of the first quality, cost in that place fourteen and a half chequins of Egypt, which is one hundred and five franks of our money (about 4 l. $6 s$. $8 d$. sterling), or tenpence halfpenny the pound.

If to prime cost is added the expense of conveying it to Cairo, the duties which are paid there, the charges for loading and unloading, those for transporting it to Alexandria, freight to Marseilles, the exorbitant and arbitrary duties with which that commodity is there loaded, as the importation of it was prohibited in France, and if to these are added commission and the expense of grinding, how is it possible to bclieve that they should have real Mokka vOL. III. 
coffec at Paris at the rate of five shillings a pound? I brought away a bag of this sweet-scented berry of the Arabian coffee-tree. The trunk which contained it las retained the perfume for years, and every time it was opened the fragrance was communicated. I even showed it to some people to satisfy themselves of the difference which existed between this coffee, and that which was sold in Irance for real Mokka.

In conversation with Mallium Poclor I expressed a desile to visit the coasts of the Red Sea, and he offered to get me conducted to Cosseir in safety. I promised to avail myself of his proposal, but it svas first necessary that I should see the Scheick Ismänsibou-Ali. I had given him my word to ivait for him at Néguadé, and I returned thither with my monk, after having been loarled with civilities by the Coplit of Kous.

I employed the stay which I was obliged to make at N'éguadé, in collecting difierent observations calculated to procure me an intimate acquaintance with the countries in which I then was. I directed my first inquiries to the most important consideration, to that which has been, in all ages, a subject of admiration, the fertility of the lands of Upper Egypt. 
In this, as in every thing else out of the common way, the love of the marvellous has introduced its exaggerated assertions. There is not, indeed, any country in the world where the soil is more productive than in Egypt. Nevertheless when, as ancient and modern authors have stated, they extend its fruitfulness in corn as far as one, two, and even three hundred grains from a single seed, they go very far beyond the common ratc. On the other hand, those who have alleged that one measure of wheat sown in the earth would produce ten, have stopped far short of the truth. I have taken and compared, in this view, the most accurate returns, and I have found that, one year with another, a crop of wheat produces, on an average, from twentyfive to thirty grains for one. And it is of importance to observe, that I am not speaking of counting the number of grains produced from a single one of which a particular ear may be composed, but that I mean the entire harvest, of the mass of corn reaped in a given district, so that every measure sown gives a return of twenty-five to thirty measurcs. In extraordinary scasons, favoured by peculiar circumstances, land sown with wheat gives a produce of fifty for one. I was even assured, at Néguadé, that, six or seven years before my arrival, a farmer had reaped onc hundred and fifty fold; but this observation, taking the accuracy of it for 02 granted, 
granted, only presenting a single and particular fact, cannot be taken into the general account. For some ycars the inhabitants have complained of the scantiness of thcir crops, although the ground had produced twenty fold during these very years which they had considered as times of dearth.

A fertility like this, which had no need of the aid of cxaggeration to appear astonishing, will still admit of increase. Ignorant and lazy, the Egyptian husbandmen knew not how to avail themselves, to the utmost, of the most fruitful of all soils ; and the means of irrigation which vegetation demands in so warm a climate were neglected, or, in a great degree, lost.

In another view, when it is considered that vegetation has no where more force and activity than in the soil of Upper Egypt ; if it is remembered that no species of plant long occupies the earth, and that many crops are seen in succession, and coming to perfection in one and the same year, the inexhaustible mine of abundance which this ancient land encloses in its wornb, must be a source of wonder and astonishment.

And this uncommon fertility is still more brilliant to the south than to the north of Egypt. Thebaiis, 
Thebaïs, which borders on the torrid zone*, would seem, from the heat of the sun by which it is warmed, from the masses of rocks which surround it, and which reflect and concentrate the heat, and from the elevation of its land, rendered thereby more difficult to inundate, to be destitute of verdure, and of the richness of harvests; it is, nevertheless, infinitely more fruit ful than the moist soil of the Delta. Its produce of every kind is more surprising. Fruit-trees overshadow it in greater numbers, and form, in a manner, forests of moderate thickness, which produce perpetual coolness, and under the shade of which you may either take repose, or travel.

Besides the vegetative force of a highly-favoured soil, the enanner in which the Egyptians sow the corn, is another cause of its great multiplication. They perceive that the method of sowing thickly, perhaps necessary in a cold and compact ground, would be hurtful in a soil warm and teeming with vegetation. The act of sowing is also carefully managed in the fields of Egypt. The sower closely follows the plough, and scatters, in the small furrow which it leaves belind, a portion of grain, barcly necessary, which the plough covers in tracing another furrow. In this manner not a single grain

* The tropic of Cancer passes a little above the cataracts, or at the extremity of Egypt. 
is lost; there are none which secm, as in our country, to be cast down purposely to feed the birds. 'The stalks, arranged in parallel lines, and separated from each other, as well as the roots which support them, easily admit the impressions of the air and of the sun; and the cars, being neither confined nor stifled, are not subject to the rickets; the grains with which they are filled soon acquire size and nourishment, and ro miscarrage or sickliness is found amongst them. Neither are their fields infected by a crowd of plants, which, under the generical name of weeds, are in the greater part of our lands a real bane to our harvests. The wheat is sown pure as it is gathered, nor is it associated with different sorts of grain in the same field, which although of a similar species, yet not ripening at the same period, cannot but produce a mixture as unproductive to the husbandman as useless to the consumer.

Ficlds enriched with such harvests as these, cannot fail to attract granivorous birds. Flights of pigeons, pairs of turtle-doves, betake themselves thither; and sparrows, which may be called the corn-bird, as they are ever found where that kind of grain is common, assemblethere about the farmhouses. The tufted lark, fixed to this fruitful land, neve $r$ forsakes it ; it seems, however, that the excessive heat annoys him. You may sec these birds, 
as well as sparrows, in the middle of the day, with their bills half open, and the muscles of their breasts agitated, breathing with difficulty, and as if they panted for respiration. This instinct, which induces them to prefer those means of subsistence which are easily obtained, and in abundance, althoughattended with some sufferng, resenbles the mind of man whom a thirst for riches engages to brave calamitics and dangers withont number.

A multitude of winged insects serve, at the same time, for food to the swallows, which never quit a climate so well calculated to afford them habitations and subsistence. The Egyptians give them an Arabian name, which corresponds with that of bird of paradise. Arrother species of birds, a great foe to insects, the laundress, so well known in the more northern parts of Egypt, is no longer to be found in these southern countries: but small flocks of ravens are now and then to be met with.

The insects there, which are the most numerous and troublesome, are the flies*. Both man and beast are cruclly tormented by them. No idea can be formed of their obstinate rapacity, when they wish to fix on some part of the body. It is in vain to drive them away, they return again the self-same moment, and their perseverance wearies out the

* Musca domestica. Lir

04 
most patient spirit. They like to fasten themselves in preference on the corners of the eye, and on the cdge of the eyelid, tcialer parts towards which a gentle moisture attracts them. I have observed a species, or rather a variety of flies, streaked with gray and dark brown, and resembling the common fly, only much sinaller. Their habits also differ, for I did not perceive that they were often on the wing, nor that they incommodcd men or animals. They were almosit constantly found in houses, fastened on the walls, and, from preference, on the whitest.

The flies are not the only troublesome insects; their houses are filled with a vast quantity of bugs, whose bites are cruelly painful. Notwithstanding this, the Egyptians, covered over with these vile insects, sleep profoundly; their skin, hard and thick, renders them impenetrable, whilst the European undergoes, in the same places, a real punishment. The bite of these buns always occasioned on my body hard swellings, and as big as the end of my înger.

An insect still more disgusting annoyed us during the whole of our journcy through Upper Egypt. The inhabitants, even of the better order, and who appear the most cleanly, are covered with lice, in spite of their frequent bathing and religious ablu- 
tions; the bey, the kiasclief, are not free from them. When they fecl themselves bitten by any of these insects, they seize it carefully, and put it, without hurting it, on the same sofa where they are sitting, from whence it is not long crasvling on some other person. Whatever precaution I conld take to avoid being formented by them, I was obliged to submit to it, and to endure the envenomed bitings of these insects, which are of an uncommon size and voracity in Egypt. When my companions were employed in clearing themselves from them, they useci jocularly to call their search hunting à la Turque.

A beautiful species of ichneumon fly , with a strong auger, and long at the extremity of the body, likewise enters occasionally the houses in Upper Egypt. It shines with the most lively colours; its head is of a bcautiful emerald green; the corselet and the belly are of a glittering purple tint.

The drone-bce, which Citizen Olivier has styled the bee with a yellow corselet $\psi$, is commonly seen here. It makes in flying a very loud buzzing. It is yet to be found in Lower Egypt. I have seen it

* Ichnexmon. Lin.

+ Encyclop. method. article Bee. Apis astums. Lin. Apis hirsuta, nigra, thorace flavo. Fabricius, Syst. Eutom. page $38 z$, and Spec. Insect. vol. i. p. 479. 
at Rossctta, but only during the warm season; it is not visible in the winter months.

The handsome sort of wasps which I have described at Rossetta*, is very cominon in Upper Eg! pt: it is met with in the fields, in gardens, and even in houses. It likes to be in the neighbourhood of water, and builds its nest in the ground.

Those frightful reptiles, scorpions, here grow to a very large size. I have been assured that their sting occasioned acute pain, swoonings, convulsions, and sometimes death.

The Nile furnishes, yet very seldom, a species of crab $\downarrow$, the flesh of which is good. The shell which covers the upper part of the body is of a leaden colour; the antenne are partly black and partly yellow speckled with black; the head, in front, is of a variegated yellowish and blackish green; the claws and nippers are of a green hue above, and of a livid yellow below; the cxtremity of the claws and the tarsus yellow; the tail is yellow in the middle, and grenish on each side.

To these details of the immutable history of $\mathrm{Na}-$ ture, I am about to add some observations on the

* See chap. xix. of the first volume.

+ Cancer fuviatilis.

fluctuating 
ffictuating history of man in society. There is not a more striking example of a thorough change in the character of nations than that which the Egyptians have undergone. Slavery, and stupidity, its inevitable consequence, have filled the place of powver and grandeur. Superstitious ignorance has succeeded to the love of the sciences, to the exercise of the arts; and perfect civilization has disappeared to-make way for brutality and savagences of manners.

It is impossible to depict the customs of a degraded people, of whom barbarism has taken entire possession, without the interfercnce of ideas so dishonourable to humanity, ideas of crimes and robberies, which blend in the picture, and constitute the greatest part of it. The vices of the present race of Egyptians have been already represented more than once in this work. It will be sufficient to add, that the men of Thebais, still grosser than those of Lower Eggpt, present an assemblage more odious; and I shall confine myself to speak of some customs peculiar to that country.

In proportion as you go up the Nile, that is to say, as you advance towards the equinoctial line, the skin of the natives colours, or rather grows dusky. In the most southern cantons the Egyptian women have a tawny complexion and a thick skin. Excepting 
Excepting foreign or wcalthy females, who have lived at Cairo, and who retain the dress of the city, all the rest have no other clothing than that full and long shift, or jacket, of blue cloth, with sleeves of an extraordinary size, and large openings at the sides, of which I have alleady made mention. This manner of dressing themselves by halves, so that the air may circulate over the body itself, and refresh cvery part of it, is very comfortable in a coun. try where close or thick habits would make the heat intolerable. But the European monks have discovercd indecency in a habit where no one else would have suspected it. They have spoken of indiscreet looks of which no one entertains a doubt, and have obliged the Catholic women to lay aside their wide and easy robe, to shut up the body in a warm and confined vesture, as if such a prohibition had not been a more real indiscretion in a country where the name of Curistian merely is a crime, and wherc cvery distinction which could recall it becane a motive to persecution. But it is not astonishing to see such inconsistcncies proceed from the narrow and bigotted brain of friars, and especially of Italian Franciscans. Thosc of Néguadé however, less scrupulous or less powerful, were the only monks who had left thingrs as they found them, and who had pernitied every onc to dress according to their fancy. 
But they all agreed in forbidding the operation, which Nalure, in giving a superabundant excres. cence to the Egyptian girls, has rendered necessary. It was sufficient that the cutting of that part, which was at least useless, bore some resemblance to circumcision, to make monkish stupidity perceive in it a Jewish or Mahometan practice, and hurl against it what they called the thander of the church, which happily was not dangerous, except in the eyes of those who were afraid of it. But it was a powerful weapon in countries where ignorance reigned exclusively; and the Egyptian Catholics, who were consequently the slaves of the monks, determined to retain an inconvenient exuberance rather than not obey the precepts of folly and hypocrisy.

Besides, these men, so busy in intermeddling with secret details, about which they have, in every part of the world, been at all times extremely curious; these very men, so careful to avoid in some points every thing which could have the slightest refercnce to the customs of the Jewish or Mahometan religion, did not trouble themselves to do away among their proselytes certain habits brought in vogue by the disciples of Mahomet. The Catholic women, probably visible to their ghostly director alone, conceal themsclves, like the Turkish ladies, from all observation, A thick veil covers their face, 
face, and they are like them retired and cloisterect up in their houses. I have sometimes been conducted, in my quality of physician, by a priest of their nation, or by an Furopean monk, to the midst of an assembly of these women. They only spoke through a nastin, and I never knew whether my pationt was old or foung. To feel the pulse, I was presented with a hand and a wrist well wrapped up, and the place was only left bare where I was to apply my fingers to the artery. Was it expedicnt to let blood? Oh! this was altogether another ceremony. 'They insisted that I should only see the bending of the arm; and I was obliged to wait fretting myself, till they had uncovered the fore part of if. If any of these women was disordered in the eycs, or had any other local complaint, it was expected that I should cure them without cxamining the eycs, or the seat of the disease; and I always left these haunts of insipidity, my mind filled with indignation at priests, who, far from seeking to wifold the germs of reason, extinguished its feeblest light, provided you were religious according to their mode, that is to say, guided by superstition, and, above all, by a thorough devotedness to their will, which, audacious profaners, they bad the effrontery to declare as the will of the Deity. 
The women of Thebais, who have embraced the Catholic religion, are again distinguished from the Mahometans by the disuse of an article of dress generally worn in these districts. It is an ornament of luxury and coquetry, which the monks have also obliged them to lay aside, for which they are not greatly to be found fault with, as it is by $n$ means becoming, at lcast as far as I can judge of it, from seeing female dancers and courtezans, who walk about without veils, disfigured by rings of metal suspended from the nose. This fashion consists in wearing onc or more hoops of gold or silver, passed through the nostrils, which are pierced for the purpose: some of these hoops are verylarge, and the richer people add to them small jewels of gold, which fail not to load the wing of the nose, and produce a very disagreeable effect. But I have never heard that it was a piece of gallantry in Egypt to kiss the women through these hoops, as Buffon has given out, on the authority of a traveller*. It is displaying much ignorance of the grenius of the Egyptians and of the Arabians, even to suppose them desirous of these amorous kisses. These people are any thing but gallant, and the dclicious preliminarics of pleasure are quite unknown to them. Besides, it is difficult to kiss a woman through a ring, which piercing one of the sides of the nose, hangs of necessity over the mouth.

* Natural History of Man.

Vansleb, 
Vansleb, whom Buffon continues to quote, says; that the women of the villages and of the populace of the cities of Egypt have sparkling eyes, a stature below mediocrity, a mode of dressing by no means agrecable, and that their conversation is very irk. some *. That the good father should find himself wearied in the company of Exyptian females, which his profession as a missionary no doubt procured him, is not at all astonishing, when it is known how far removed these women are from our means of knowledge and from every species of education; that he was not satisfied with their dress, although light, cool, and comfortable, I only say, let every one judge for himself; but the reverend father has fallen into a mistake when he says that they are of short stature, for, in fact, the Egyptian women are, generally speaking, as tall as the French. It is true that Vansleb was a German, and that the women in that part of Eirope are for the most part tall and slender. The Egyptian femalcs are neither so tall nor so well made.

It is not usual to find jealousy without love. The women of Upper Egypt, however, who neither love nor are beloved, are somctimes seized with a jealous madness, when they discover that their husbands have any partiality for other women, a par-

* Buffon, Natural History of Man; and Vansleb, New Account of Egypt. 
tiality common enough, and in which mere animal passion is every thing, while the heart is totally unaffected. Offended pride lays strong hold of a breast once inflamed, and which knows nothing of love but its transports. Dissembling as well as cruel, they instil a slow but mortal poison into the blood of a faithless husband. Examples of a revenge, which even the delirium of an amorous passion cannot excuse, are daily to be seen. Their blows are meditated in silence, and they indulge coolly, and in large draughts, the dreadful pleasure of depriving an unhappy being of his life. I have not actually witnessed what I am just now going to relate, but they are facts which have been unanimously attested to me, and which are considered in the country as certain and un. doubted.

These women, desperately wicked, are not willing to inflict a quick and sudden death; with this their remorseless jealousy would not be gratified; but they bring on a gradual decay more intolerable than death itself. In themselves they find the poison which promotes their views. The periodical discharge, which Nature employs to preserve their existence and health, becomes, in their hands, a mean of destroying others. Mixed with some food, a portion of this discharge is a poison which immediately throws him who swal-

YOL. III. 
lows it, into languor and a consumption, and leads him to the grave. It is said that the women take care to make ready this horrid repast at certain periods of the moon, during which it ought, in their opinion, to produce more certain effects: those of this poison are tcrrible indeed. The symptoms are nearly the same as in the scurvy. The body dries up; all the limbs become excessively feeble; the gums rot, the teeth are loosen$\mathrm{cd}$; the beard and the hair fall off: in a word, after having dragged out a tedious and painful life for a tivelvemonth, and sometimes longer, the wretched victim expires in the midst of sufferings. No remedy is known for so many horrors; it is even asserted that nothing is able to alleriate them.

This leads me on by a natural transition to mention some remarks, which the practice of physic in Egypt enabled me to make. I have observed that it is not casy to purge its robust inhabitants. Their stomach, accustomed to digest bread badly baked, acrid and raw vegetables, and other gross and unwholesome nourishment, is not easily affected by purgative medicines. Doses which in Europe would occasion the most violent super-purgations, glide harmlessly over their iron stomachs. I have seen eight grains of very strong tartar emetic produce no other cffect than some slight 
slight retchings. I have sometimes administered, with fear and trembling, very powerful medicines, which made no more impression on my patients than if they had drank a glass of water. The monks for the propagation of the faith, who maintained themselves in those countries by the practice of physic, successfully made use of a purge for the natives, which they might have administered with as much propriety to horses, and which they compounded of aloes, the coloquin. tida, and a quantity of gum. Of these they formed pills, and a drachm was a dose.

The leaves of the senna, a plant indigenous in the southern extremity of Egypt, are there taken in large quantities without inconvenience, and almost without effect. Perhaps fresh senna has not the same purgative virtues as it has when dried; like the manna, which is used as a substitute for sugar in victuals and pastry at Kurdistan, Diarbekir, Ispahan, and other countries of Asia, and of which the inhabitants consume a great deal without being purged *.

I have already said, that diseases which attack even the sources of generation were very common in Egypt. They have found their way to the most remote corners of it. The monks cured them

* See a Description of Arabia by Niébuhr, p. $\$ 29$. 
very skilfully. They did not use mercury in their mode of treatment, but simply employed sudorifics; and so far from putting their patients under a regimen, they, on the contrary, advised them to indulge in a variety of foods. The Arabians have a way of curing those disorders peculiar to themselves. They dig a hole in the sand, and bury themselves in it up to the neck; they remain in this position without eating, exposed to the most intense heat during the whole day. In the even. ing only they take a little nourishment. I have been assured that they resumed these scorching situations for twenty or thirty days together.

But a very singular fact, and which, however, I by no means guarantee, although it has been sworn to by many people, and among others by the friars of Néguade, is the wonderful property which they ascribe to the smoke of mastich*, namely, that of killing every sick person who breathes it. It is possible, nay probable, that this is only a prejudice, but it is so deeply rooted, and so generally received, that nobody doubts the deadly quality of burnt mastich. As I said before, they perfume with it the porous vessels of unbaked earth, into which they pour the

* A resinous substance, which, in the islands of the Archipelago, and particularly at Scio, oozes from the lentisk. Pis. sacia lentirius. Lis. 
waters of the Nile to cool. One day the monks of Néguadé were employing themselves in this operation at the gate of the convent, ignorant that there were any sick people in their vicinity. Immediately a woman in tears was seen issuing out of a contiguous house, running with all her might, and carrying in her arms an infant seized with the small-pox. When she had put the child in a place of safety, she returned to the convent, uttering loud shrieks, and endeavouring to stir up the people against the Franks, who, she said, had endeavoured to destroy her child. When any one, accordingly, burns mastich in the open air, he is careful to inform himself beforehand if there are any sick people in the neighbourhood; for they believe that, whatever the nature of the disorder may be, the smoke of that rosin causes instantaneous death whenever it is respired, 


\section{CHAP. XLIX.}

The effects of missions in Egyp-Character of the European monks who teside there-Perfidy of those of N'éguadé-The author's farervell to IsmainnAbou-Ali-The gardens of Kous-Citron-treesGrapes-Melons-Waier-melon-Dates-Doum -The real acacia-Sésame, its oil, mode of preparing it-Diseases of the skin at the period of the swelling of the Nile.

THE name of Franks, which in the East denotes all the Europeans of whatever country, held in esteem among the Turks, despised in the cities of Lower Egypt, was considered with horror by the inhabitants of the Said. This hatred is instilled by the Cophts, who are more numerous here than in those districts farther to the north. They fclt sore at the arrival of some missionaries who came from Italy purposely to preach against them, to expose them openly as heretics and dogs, and to damn them without pity.

Intolerance of this kind, these pious injuries, had perhaps merit in the view of theology; but they were extremely prejudicial to commerce and to the increase of knowledge. Indeed, means of this na- 
ture intercepted communications already so embarrassed, and shut up the passage against Europeans who were not missionaries, and who might reasonably have pretended to be more useful than Recollects, who converted nobody, and rendered the name of Franks contemptible, by a life superciliously mendicant, and burdensome to the small number of Egyptian Catholics; for all their science consisted in making dupes; and as the people were not endowed with sufficient discernment to distinguish missionaries from any other Europeans, they supposed we only went to Egypt in order to insult the Cophts, and to exhibit thern under the most unfavourable colours. Numerous, because they are, indeed, the true Egyptian race, and powerful because they possess the confidence of the great, whose affairs they superintend, these aborigines, so different from their ancestors, $\mathrm{cx}$ erted their influence, on the other hand, to represent the Franks as dangerous and despicable men. From thence arose principally those obstacles which the traveller into Egypt had perpetually to overcome, so that these missionary establishments, formed for the purpose of advancing the interests of Heaven, were useful to nobody upon earth, and became prejudicial to the progress of science, by obstructing tìe way of resolute men, who devoted themselves, in the milst of dangers, to the advancement of human knowledge, and to

$$
4 \text { which, }
$$


which, by the by, the monks were by no means instrumental. On the contrary, there is not an European traveller who has not had reason to complain of hypocrites, whom distance and their acquaintance with the country rendered more formidable.

No one has had better opportunities than I of knowing the mind of perverse men living by imposture and quackery; their greatest care was to get their fellow-citizens, whose power they feared, out of the way, and they neglected nothing to get rid of them.

The superior of Néguadé had been informed of the reception which $I$ had met with from IsmainnAbou-Ali, and of his desire to retain me with him. This plan was not to his purpose; he perceived with uneasiness that another European, not a monk, was about to enjoy a reputation which he wished to reserve for himself alone; he determined to send me out of the way. Whilst I was puzzling my brains to find out some expedient which should rescue me from the over-abundant kindness of -an Arabian prince, whom it was not my plan either to follow or to serve, the monk, who only devised the means how to be mischievous and perfidious, and who, very much agrainst the grain, had become officiously kind to me, was tormenting himself in his turn how to counteract the Arabian's desire to re- 
tain me. We had learned that Ismain was at hand; he slopped in the little village of Kamoule, a short distance to the south of N'éguadé. The superior went thither secretly; and his conversation, which an Arabian, to whom I had been of use in my medical capacity, related to me, turned entirely upon myself. The hypocrite began by complaining that the confidence of the prince, which, in his own opinion, he had acquired by a long and thorough devotedness to his service, appeared to diminish. "It seems," added he, "that the arri"val of a stranger has injured me with you; but " exclusive of this stranger's belonging to a coun" try where the inhabitants are impious, be assured " that you will be greatly deceived, if in keeping " him you expect to find a physician; he never "was one; he is a soldier in disguise, and the "profession of physic is only a mask which he as. "sumes, in order to visit with more facility, and to " know more perfectly, the country which you go"vern with so much glory and dignity. The re" medies which he might administer to you, pre" pared by an ignorant hand, might poison instead " of healing you. You know that during the ten "years in which I have acted as your physician, "I have often relieved you by my prescriptions; " by my skill I have lately discovered new medi" cines, which will restore your health and vi"gour. I bring them with me; make the trial, s' and 
" and you will then be cnabled to judge whether "I am worthy of your favour, and deserve the " preference to an adventurer."

If this harangue had been addresscd to a bey, it would have been all over with me; there would have been no punishment severe enough to have crpiated a pretended imposition, and my death would have been inevitable. The infamous monk well knew to what he exposed me; but do the feelings of humanity ever enter the bosoms of hypocritical monks? And what did it signify to him whether I perished or not, provided he could preserve his reputation, and continue at his ease, and without a troublesome witness to the practice of more seriousdeceptions? Ismä̈ discovered no mark of displeasure, and the friar had not even the satisfaction of knowing whether his scheme had produced the desired effect. I heartily rejoiced at the service : which he had unintentionally performed for me, and I affected to be sensible of his attentions, which he never lavished on me so plentifully as after he had betrayed me. At length the Arabian prince arrived; he encamped as usual without the precincts of Néguadé. I went to present myself before him in his tent. He received me with marks of distinction in the presence of the monk himself, whom he left standing whilst he made me sit by his side, as a token of the contempt he felt for a 
vile defamer; but he no longer urged my staj. I acted as if it had never been spoken of, simply asking of him assurances of protection and favour in facilitating the remaining travels which I proposed to make in the principal towns of Thebais, which I had not yet seen. He immediately ordered letters of introduction to be made out, and carried his attention so far, as to give orders to all his overseers to defray my expenses at his cost in every part of his dominions which I should enter: of this generous foresight, a proof of the Arabian's greatness of mind, I did not avail myself. We parted very well pleased with each other; Ismaïn in not having me for his physician, and $I$ in not being employed to work the miracle of restoring him to youth again.

I made haste to leave the convent of Néguadé, the abode of treacherous hypocrisy, not without having made the superior feel that the villany of his conduct was known to me, and passed on to Kous, where I arrived the 4 th July in the evening. Mallium Poctor, the same Copht at whose house I had already spent a day, received me very civilly, and procured for me a lodging sufficiently comfortable, in which I proposed to wait the departure of the caravan for Cosseir. It had been arranged some days before; but accounts were received 
ceived that the Arabs occupied the road which it was to take, and the time for its setting off was therefore delayed.

Kous is surrounded with fruit-trees, which form very agreeable orchards. These trees are, indeed, planted without order; they do not present that symmetrical arrangement which is generally called the work of taste. Here it is the work of nature, and those who love its beautiful simplicity, experience sensations more delicious, more satisfying than the impression of astonishment produced by the efforts of art, when it attempts to imitate nature. Besides, where can be found a foliage more variegated, a shade more sweetly scented? Fruits of every kind ripen there, and their boughs intermingle and blend together. Their flowers, which the warmth of this climate renders more odoriferous, exhale a fragrance which they acquire no where else ; and under a temperature constantly heated, the real hot-house of $\mathrm{Na}$ ture, trees the most agreeable, and which in our frozen climates languish in confinement for the greatest part of the year, are loaded uninterruptedly with blossoms and fruits. The wealthy Poctor conducted me into one of those gardens which belonged to him. I never found myself before under so delightful a shade. The air was filled with the 
sweetest exhalations, amid which prevailed the exquisite odour of the blossom of the citron-trees, which were there in great numbers.

It was the season when grapes are found in most abundance. Long clusters were filled with large purple fruit, the pulp of which was sweet and aromatic. This is the fruit most esteemed by the opulent, and that which they consider as the most agreeable alleviation of the heat occasioned by the climate. Common and water melons, fruits equally refreshing, filled the market-places and streets of Kous. I there ate of three sorts of melons, the agour, resembling the melon of Europe, but whose form is not always similar, some being round, others oval, and a third sort extremely long; the ahoun, a species of cantaloupe, the rind of which. is yellow, and the pulp of a yellowish white; and lastly, the abdelavoui (the slave of sweetness), which is lengthened out, and remarkable on account of a rounded protuberance which it bears close to the stalk. 'There is no one of all those melons of so good a quality as our choicest European melons. The greater part of them are insipid. The cantaloupe, more famous elsewhere for its flavour, is there very tasteless. That kind, the name of which would seem to indicate the softest and sweetest pulp, is called the slave of sweetness, only because it rcquires a great deal of 
sugar to make it palatable. The water-melons, on the contrary, are exceilent in Upper Egypt, as I have already observed. I found a species or variety of them at Kous, which I had not seen till then; its form is very long, its sides are but slightly marked, and it swells to a very large size. This species, which is not inferior to the rest, the Arabians call nem; it is also the name of the mangouste, the ichneumon of the ancients, a fourfooted animal, celebrated with so little reason.

Dates had begun to ripen; new ones had been eaten from the beginning of the month, but they were still scarce. The palm-tree which produces them, overtops with its shady summit all the places of Egypt; whercas the doum, another species of palm-tree, peculiar to Thebais, more wild, and for which a single slender stem is not sufficient as for the date-tree, loves not to be so close to habitations, but flourishes better in the fields, which it overshadows and adorns.

The real acacia, which distils gum arabic from its trunk and branches*, grows commonly on the parched and almost barren plains of these identical parts of Upper Egypt. Its port, for the most part stunted; its trunk crooked and short; its branches long and few, with narrow and thinly scattered * Mimosa nilorica. Lin. 
foliage almost bare; a very rough bark, and of a deep brown; long white prickles, with which it is beset, give it a harsh and withered look, which induce you to mistake it for one of those leafless trees, and whose sap chilled by the frost, during our winters, reduces to a state approaching death. Very small flowers, white or tinged with yellow, and almost without smell, are but ill qualified to make up for what it wants in point of appearance and foliage. This tree, which the Egyptians call sunth, and not santh, as I observe most authors spell it, will never then be reckoned among the number of ornamental trees, but its usefulness will ever make it considered as one of the most valuable. Its wood, of a deep red colour, is hard, and capable of receiving a beautiful polish. Its seed, enclosed in a husk very like that of a lupin, yields a red colour, which is made use of in dying morocco. The goats are very fond of this fruit, which, in the Arabian tongue, is called karat; pounded together with the husk before it comes to maturity, it affords an astringent in piarmacy, known by the denomination of essence of acacia. But the gum which distils from the numerous crevices of the bark of the acacia, or from incisions made in the trunk and greater branches, is an object of importance in commerce and manufactures, in which great quantitics of it are consumed. Excessive heat is requisite in the production of gum arabic. 
arabic. Indeed, although the acacia thrives in the more northern parts of Egypt, yet it produces no gum; in Thebais, on the contrary, where the temperature of the air is scorching, I have seen it entirely covered with hard and coagulated tears of this mucilaginous juice.

In more skilful hands than those of the Egyptian husbandmen, the acacia might become a powerful mean of restoring to cultivation the lands of Upper Egypt, which sterility has taken possession of, and the soil of which, fit for cultivation, is covered over with vast layers of intrud. ing sand. However dry or clayey the ground concealed by the sand may be, yet the gum-tree may be planted and brought forward there, provided the roots fasten in a bed of vegetable earth; the sandy layer which might surround the bottom of the trunk would not injure its growth. Forests of the acacia-tree would soon bring back vegetation and inhabitants to a soil which different circumstanccs seem to have condemned for ever to a barren depopulation; and during the period till cultivation shall again flourish, the gum arabic would produce so advantageous a revenue, as to leave no room to regret the expense of such a plantation; besides, the excellent wood which it might supply, would be no small indemnification in a country where wood is so very scarce. 
At Kcus I was presented at a dimer, for the first time, with tahiné. It is thus that the Egyptians call the dregs of the oil of the sésame, to which they add honey and citron juice. This ragout is much in vogue, but, in truth, without deserving it ; for, disagreeable to the eye from its colour and its half-liquid consistency, it is still more so to the palate from its tastc. The oil which is extracted from the seed of the sésame, and which is called in Arabic siritch, is also highly valued in Egypt. It is preferred to that of the olive, to which it is greatly inferior; and, in all likelihood, Europeans will never consider it fit for any other use than to employ in the lamp and the frying-pan.

It is not only of late that the sésame and its oil have been held in repute in the East. The Babylonians (the ancient inhabitants of Bagdad), according to Herodotus, made use of no other oil than that which they extracted from the sésame*. Pliny mentions it as being equally unfit to eat or to burn $\gamma$; and Dioscorides says that the Egyptians made many uses of it 4 . It is likely that the present inhabitants of the same country, very igno. rant in the manipulation of oils, since that which they extract from tue olive is very bad, and fit only

* Lib. i. French transłation, and note of Citizen Larcher. † Lib xviii. cap. so. $\ddagger$ Lib. i. cap. $\mathbf{2} \mathrm{s}$.

VUL, III.

Q 
for the composition of soap and the use of manufactures, know not how to impart to the oil of the sésame the qualitics which it is capable of, and which in all probability it formerly possessed.

Natural to the warmest climates of the Old Continent, the plant which was then called semsem is known in Europe by the name of sésame, and sometimes by that of jugcoline, which has no connexion with its original denomination. It resembles the fox-glove in a great measure* IIs cultivation is very general in Egypt, and over several cantons of the Levant; it even begins to flourish in Italy; but I have scen the seeds of the sésame there, which were much smaller and worse filled than those of Africa. This plant also thrives very well in French Guiana, a colony neglected, and of no reputation, but from which, however, France might derive great advantage and considerable wcalth. The negroes there cultivated the sésame in their gardens, and extracted from it an oil, which proved a balm to ivretches equally worn out by excess of labour and by privation of comfort.

Exclusive of their economical properties, the sésame and its preparations are besides in use

* Digitalis orientalis sesamum dicta. Tournef. Inst. Rei herb. Sesámum indicum, Lin. 
amongst the Egyptians as physic and as cosmetics. Their women fancy that nothing is better adapted to give them that embonpoint which they all wish for, to clean their skin, and to give it bloom and freshness; to preserve the beauty of their hair, and also to increase the quantity of thcir milk when they become mothers. Medicine also finds in it real or supposed means of cure in several diseases. If these healing virtues are not more efficacious in other maladies than in the inflammatory ones of the eyes, for which the Egyptian physicians recommend this oil, upon my word they will not acquire much confidence, for there is not a country in the world where the organs of sight are more frequently affected with numerous diseases, to such a degree, that eyes perfectly sound are seldom to be met with, excepting, perhaps, those of the women, which their veils defend against the keen and penetrating impressions of the air.

I have already, in the former part of this work, pointed out some of the causes of those disorders of the eyes really endemical in Egypt, and which render this country, excellent in other respects, an unpleasant and dangerous abode. I have given it as my opinion, that the chief of these causes was the great quantity of water with which the streets and houses of the cities were sprinkled several 
times a ddy, in order to moderate the heat, and to coul the air which was respired. When earth, violently heated, is moistened so plentifully, it sends up a great quantity of nitrous and inflammatory vapours, which cannot fail to impair and injure the sight: but it is impossible to include the custom of the inhabitants, to sleep in the open air, among the many circumstances which make ophthalmy and blindness so common in Egypt, as many persons have supposed and written. Indeed, although the natives of Upper Egypt, where the heat of the sun by day occasions them to sigh for the cooling breczes of the evening, have no other bed than the terrace of their huts, yet they have nothing to fear from that habit, for they wrap up the whole body so carefully, and particularly the head, that you must be an Egyptian to escape stifling under the folds of cloth with which they cover and shut up their face, so as even to intercept respiration. Besides, it is well known that the peopie of ancient Erypt did not in general sleep so much exposed, and nevertheless they were equally subject to blindness and the ophthalmy.

It was now, as I have before observed, the time of the swelling of the Nile. The goutte, that miraculous dew, which, according to the belief of the Egyptians, purifies the atmosphere, and prescrves 
from corruption those seeds and roots which are exposed to be moistened by it, had fallen, and they were still talking at Kous of its wonderful effects. This circumstance gave me an opportunity of cxamining a cuticular disease, attributed to this dew of one night, and which is the natural consequence of an excessive heat at that scason of the year. I saw screral people whose face and body were covered in many places with large pimples, which they call halie Nili (sprouts or seeds of the Nile), and which resemble those of an ordinary eruption, only that they rise much more considerably. This indisposition, which is by no means dangcrous, and which goes off of itsclf, is perhaps the same with the pelegra of the Milanese, and the mal de la Rosa of the Asturias. I have heard it asserted that it attacked strangers more commonly than the natives of the country; notwithstanding, out of four Europeans which formed our party, not one of us was affected by it. 


\section{CHAP. L.}

Treachery of a Copht-Character of the men of that nation-Dangerous underhand dealings which obJige the Author to give up the voyage of the Red Sca-Wasp-New war in Upper Egsp-Westers side of the ancient city of Thebes-GourneiWicked men by whom that village is inhabitedFragments of antiquity-Disagreeable night passed at Gournei-A sick man-Physician of the country - Route from Gournei to Néguadé.

$A_{N}$ inconceivable fatality seemed to detain me in Egypt whenever I attempted to leave it. Already had my journey into Abyssinia miscarried at the moment in which I was entering on it, and similar motives again obliged me to give up my voyage to the Red Sea. I found myself surrounded by villains who conspired to make me their dupe and their victim. The Catholic Copht of Kous, Mallium Poctor, who had so often promised to see me conducted to Cosseir, and who had welcomed me at first with the appearance of cordiality, was, like all his fellow-citizens, nothing else but a traitor, and the more dangerous from inveterate habits of perfidy and dissimulation. The Mameluc who commanded at Kous often cautioned me to 
be upon my guard. He knew Poclor, and looked upon him as a rogue of whom I could not be too distrustful. I here feel it incumbent on me to say, that for the most part I have had better reason to applaud the conduct of the Mamelucs than the natives of Egypt. With a character more rough and unpolished, these strangers possessed a certain pride and a blunt harshness which rendered them indeed formidable to men subject to their despotic sway, but which, by inspiring them with a kind of greatness of soul, gave you full dependance on their protection and promises; whilst the Copht, dark and designing, insinuating and deceitful, distinguished himself by the cringing and submissive deportment of the most abject slave.

The attention which the Kiaschef paid me, was a bridle on the robbers into whose hands I had fallen. But an order from Cairo, in removing him from his command, deprived me of his support, and the same inen, who but a moment before trembled at his feet, no longer paid him any respect when they knew he had lost all authority. Poctor, in order to rob me, had associated with a Turkish merchant, and it must be acknowledged that they were a couple of the most accomplished liars and swindlers. The preparations for my journey to Cosseir afforded them innumerable pretences to ask me for treats and money. The Copht had alrcady received a telescope, 
a pair of pistois, and several bottles of liqueurs, and there was not one of my little moveables which he did not cxpress a desire to have. He boasled greatly to me of the pains which his friend, the Turkish merchant, was taking to expedite my journey, and he made me promise to acknowledge services so important. I sent accordingly to the latter another valuable telescope; but he refused it, giving me to understand that as he was not the captain of a ship, a telescope would be useless to him, but that he would very willingly accept money instead of it.

He had already taken but too much from me. Sometimes he asied it to sccure the hire of the camels which were to carry me, sometimes to make an advance to the guide of the caravan; at another time his exertions required a salary; at length he had choused me out of five and twenty chequins in one way and another, without the slightest appearance of any further preparation to proceed. A caravan was preparing, they told me, to set off; some Arabians dispersed throughout the desert which it was obliged to crose, had retarded its departure; a few days after there was no caravan; and some fleet camels were to convey me very speedily to the flat shore of the Red Sca. But it was requisite, according to this new arrangenent, that I should leave my baggage with the Turkish merchant, who was to forward it to me by a future caravan. 
The snare was a little too gross, and finding it altogrcther impossible to trust to such people, I told them, that, unwilling to submit any longer to their roguery, I had given up all thoughts of my journey to Cosseir. This determination did not at all accord with the views of Poctor and of the Turk, and they did all they could to persuade me from it. But when I reclaimed the money which I had advanced for a journey now given up, they exclaimed bitterly against me. According to their account, I was still indebted to them for what they had done. I threatened to lay my complaints before the Arabian prince, Ismain-Abou-Ali; they then brought me back five chequins. I gave up the remaining twenty rather than continue any longer exposed to the plots of these two rascals, and determined to continue my route towards the ruins of the ancient city of Thebes.

As I was collecting my effects in the sort of chamber which I occupicd, I perceived that a species of large wasp, with violet-coloured wings, had built its nest in the inside of the wooden case of a large mariner's compass; the honey-comb, nearly of an oval form and pierced with a round opening in the middle, was upon the ground; cach cell contained a maggot rescmbling a small worm, of a meadowgreen colour. Around this honey-comb there were others which had been begun and lefi unfinished.

The 
The excessive heat of the sun rendered the country through which I was passing truly a torrid region. During my stay at Kous the thermomcter of Réaumur, placed in the shade, rose to thirty-five degrees.

We left Kous the r $7^{\text {th }}$ July, accompanied by four Arabs. We followed the Nile on the eastern side on horseback. We stopped in the middle of the day at a village, the name of which, Nouzarie, indicates that it is pcopled by Cophts or Christians of Egypt. We soon rcached Karnak, a miserable village, whose cottages would serve to heighten the magnificence of the splendid ruins which surround them, if there were any thing in the world to be compared with the remains of Thebes, that famous city of antiquity which was celebrated by Homer. Luxior, another village, built at the southern extremity of the seat which this illus. trious city held on this side of the river, lies about a leagne farther off. It would have required more time than I had to spare, and more safety than was to be found in this soil, covered over with ruins and lighway robbers, to have minutely examined relics which immortality had preserved amid the shock of ages and the rage of barbarism. It would be no less difficult to describe the sensations which the sight of objects so grand, so majestic, raised within mc. It was not a simple admi. ration 
ration merely, but an ecstacy which suspended the use of all my faculties. I remained for some time immoveable with rapture, and I felt inclined more than once to prostrate myself in token of veneration before monuments, the rearing of which appeared to transcend the strength and genius of man.

Obelisks, colossal and gigantic statues, avenues formed by rows of sphinxes, and which may still be traced, although the greater part of the statues are mutilated or concealed under the sand, porticoes of a prodigious elevation, among which there is one of the height of a hundred and seventy fect by two hundred fcet breadth; immense colonnades, the pillars of which are twenty and some thirty-one feet in circumference; colours sti!l wonderful on account of their brilliancy; the granite and marble lavished on the buildings, stones of high dimensions supported by capitals and forming the roof of these magnificent edifices, in a word, thousands of columns overthrown, occupy a space of a vast extent.

Let the so much boasted fabrics of Grecce and Rome come and bow down before the temples aud the palaces of the Thebes of Egypt. Its lofty ruins are still more striking than their gawdy ornaments; its gigantic wrecks are more majestic than their perfect preservation. The glory of the most celebrated fabrics vanishes before the prodigies of 
Egyptian architccture, and to describe them just\}y a man must possess the genius of those who conceived and executed them, or the eloquent pen of a Bossuct*

The

* Having retired in the eveninz to one of the cottages of Luxor, my imagination still filled with the wonders I had seen, I again read with enthusiasm the passage from Bossuet, in which he draw's, after the narrative of Thevenot, an hasty sketch of the ruins of Thebes. It is impossible to speak in a more tlevated style, of works which command admiration and respect. I thiuk it will gratify the reader to be presented with this passage, which will help to give him an idea of places worthy of the pencil of the French orator.

"The works of the Egyptians were made to resist the effects " of time: their statues were colossal; their pillars were im" mense. Egypt aimed at vast objects, and sought to strike " the eje at a distance, but always gratifying it by justness of " proportion. Temples and palaces, to this day almost entire, " where these pillars and statues are innumerable, have heen " discovered in the Saïd, which you know well is the name of "Thebaïs. One palace above all is admired, whose remains " seem to have subsisted oniy in order to efface the glory of all " the greatest productions of human power and skill. Four " alleys extending firther than the eye can follow them, and " terminating at each end in sphinxes of a composition as rare " as their size is remarkable, serve as avenues to four porticoes " whose height astonishes the beholder. What magnificence " and what extent! Indeed of all those who have described the " prodigious edifice no one has had time to make the tour of it, " nor are they even certain of having seen the half of it; but " all that they dicl see there was surprising.

"A hall which apparently stood in the middle of this superb "palace, 


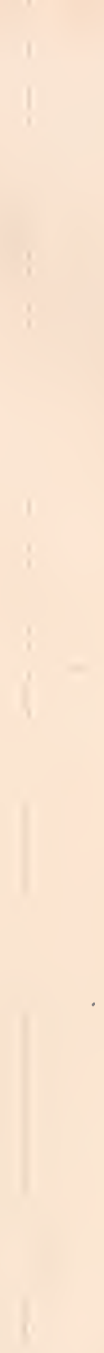




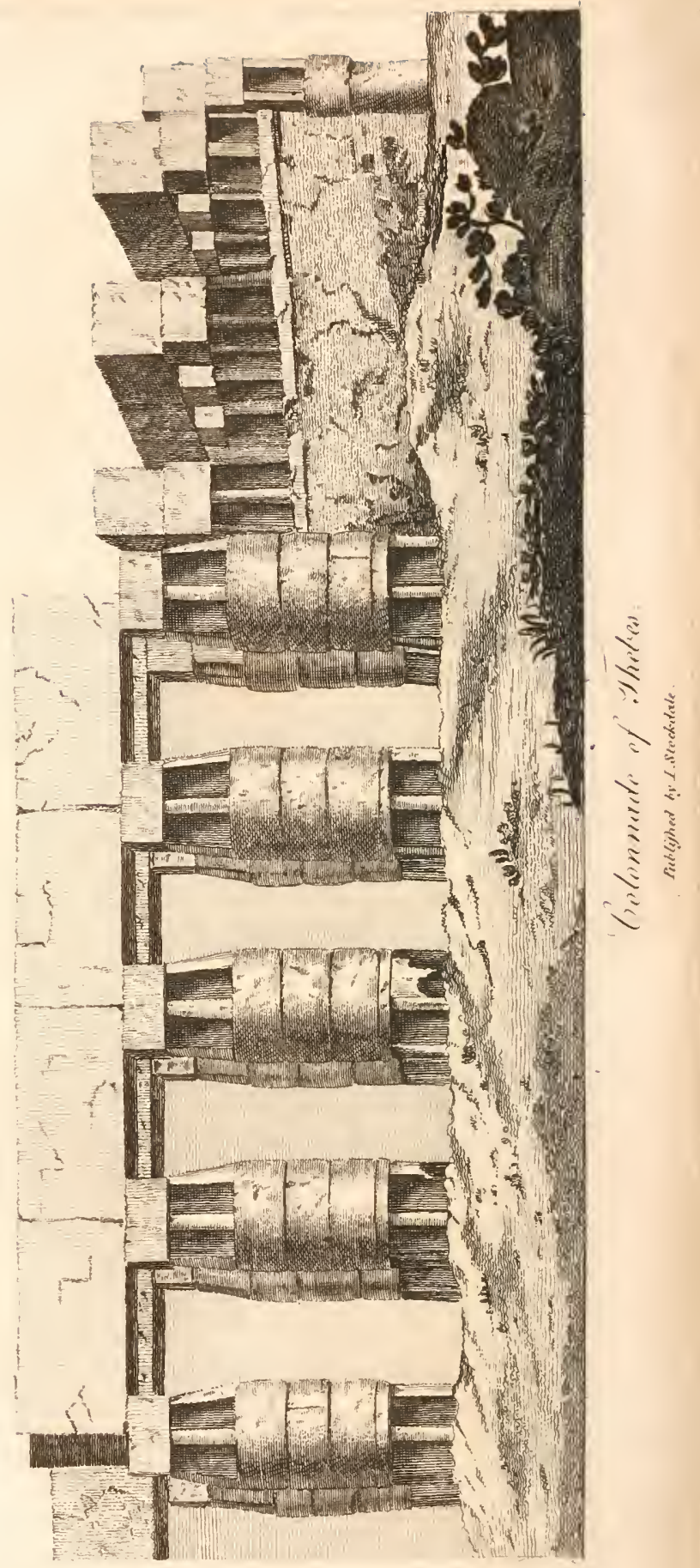


The Arabian who commanded at Luror for Ismazin-Abou-Ali, and to whom I presented a letter from that pince, received me very well. We mounted our horses on the $18 \mathrm{th}$, and made, under his escort, the tour of the ruius of the ancient residence of the kings of Egypt. The magnificence which it displayed, and the extent of its circumference, exceed all belief. But new events occurred to hurry me away from ruins of which I intended to cxamine the most remarkable parts and to take drawings of them. The ouly one which I had time to get delineated is given in plate XXXIII. which represents a singular colonnade of that portion of the ruins which surrounds the village of Luxor. Upper Egypt was again about to become the theatre of a war between the Mamelucs. Some Biys belonging to Ismazir s vanquished party had found means to penetrate into Thebais, as far as the Red Sea, and to acquire a sufficient number of partisans there to occasion some alarm to the victorious Mourat Bey. The latter sent a small army, commanded by a Bey of his own family, to extermi-

\footnotetext{
" palace, was supported by a lundred and twenty columns, ot " six fathoms in thickness, and lofty in proportion, and intcr" mingled with obelisks which so many ages have not been able " to lay low. Even colcurs which yield the soonest to the " power of time still endure an:d the ruins of this wonderful "edifice and preserve their vivacity; so well did Egypt know "how to impress the character of immoriality on all her "works." Disc. on Univ. Hist. part iii. sect. iii.
} 
nate the remainder of his enemies. I was between two bands of combatants, equally undiscipliued and untractable, and both disposed to commit the greatest excesses. The disorder attached to these troops, of which the men who composed them posscssed none of the qualifications of a true soldier but his bravery, infected the districts through which their cohorts passed. Themselves plundering and destroying, they left the country open to plunder and devastation. Robbers stripped travellers by land, and pirates seized the boats on the Nile. Clans of Arabs rencwed ancient quarrels, and had frequent skirmishes together; one village fought against another; in a word, on these occasions, violence, confusion, and licentiousness, werecarried to their highest pitch; and the stranger unprotected, because authority no longer existed, could not fail to fall a victim in the general convulsion.

It was impossible for me to remain any longer in the places which the superb city of Thebes formerly filled. These cantons, very dangerous even during the most tranquil periods, were on the eve of becoming unpassable for every one but robbers. Neither could I think any more of advaucing towards the cataracts. Exclusive of the perils I should run from a more barbarous population in that scuthern country, the enemies of Mourat, into whose hands I might be delivered, would certainly 
certainly have destroyed me, as being one of his creatures. I accordingly took, very much against my inclination, the only step which remained, that of going down the Nile again, the ferocity of the inhabitants softening a little, as well as the darkness of their colour, in proportion as you return towards the north; besides, I had less to fear in falling in with the partisans of Mourat Bey.

The Arabian Scheick of Luxor urged me not to delay my departure, but I wished to go once more to the western bank of the river to Gournei, in order to view the remains of the ancient city of Thebes, which were on that side. This point of Thebaï was considered as the most dificult of approach on account of the multitude of robbers by whom alone it was peopled. I have heard the Kiaschef of Kous say, that he dared not travel there with his small party of Mamelucs and soldicrs. The Scheick of Luxor, one of those whose upright and hospitable behaviour appeared to a greater advantagc in a country where they are accustomed to promise much and to perform nothing; this Scheick, I say, also endeavoured to dissuade me from my plan; and when he saw that I was resolved not to give it up, he pointed out to me, with much polite condescension, the prudential arrangements which might contribute to my safety. This gallant man would accompany me even to the boat which carricd me 
on the morning of the 29 th before Gournei to the west of the Nile.

I was about one hundred and thirty-five or onc hundred and forty leagues from Cairo, when I gave over advancing in a southern direction.

The place where I disembarked was planted with gum acacias. Although the village was not far removed from the river, I rcquested, and this by the advice of the Scheick of Luxor, the Scheick of Gournei, for whom I also had a letter from Ismazin, to come himself to the bank of the Nile. He arrived immediately, and conducted me to the most pitiful, the most frightful place, from its miserable appearance, which I have yet met with. The huts which compose it, vilely constructed of mud, are not higher than a man, and are merely covered with some branches of the palm-tree. And the men! I never had seen any of so dire an aspect. Half black, the body almost entirely naked, their miserable rags covering only a part of it; their physiognomy gloomy and hagard with ferociousness; following no trade, without taste for agriculture, and, like the savage animals of the parched mountains near which they live, appearing to live solely by rapine; their wholc aspect had something terrifying in it. 'The Arab who represented Ismuin there, had no 
great authority, and what he told us of the horde of Gournei was but ill adapted to inspire courage.

My companions, whose imagination had been struck by all that they had heard related of this truly detestable place, appeared very much alarmed ; the Syrian interpreter, as cowardly as villainous, shed tears of dismay; all blamed me severely, and doubted not of our destruction when they saw me seated upon the sand in the midst of a dozen of these rascally fellahs, pulling out my purse every minute, and paying the price of the idols or antique medals to all those who brought me any. I by these means made a tolerably large collection of fragments of antiquity; and I must say, in favour of the inhabitants of Goumei, that they observed the same good faith and precision in these little dealings, which occupied us a great part of the day, as if they had been the most upright people in the world.

Almost all the medals which I purchased were of very small value. The greatest number of them were copper, and Ptolemies. There were three or four golden coins, but they were Arabian. Very beautiful cornelians are commonly found among the ruins, ready cut and fit for the engraver. Amongst the objects of antiquity which were presented to me, a man shewed me one for which he demanded

VOL, III. א

an 
an extravagant pricc, although it was a trifing thing, an arnulet of baked earth representing a figure with two faces. But the possessor had the address to attach an imaginary value to it, and to draw thence a small revenue, founded, like all others of the same sort, on folly and credulity. The women cowsidered this talisman carried about them, as an infallible means of procuring safe deliverance in child-birth, and they even paid thirty medinas for the hire of it for a single day.

The western part of the ancient city of Thebes does not yield in magnificence to that which is separated from it by the Nile; but the monuments are not so well preserved, and the wrecks are there heaped up in the greatest confusion. Some pieces still remain as unshaken witnesses of the astonishing solidity of the edifices which were there constructed. The front of the walls of an ancient temple quite covered over with hieroglyphics is yet to be seen; a superb portico, colossal statues, among which are to be distinguished fragments of the statue of Memnon, which uttered sounds at the rising of the sun, and which was considered in former times as a miracle. I could only hastily view, with looks of admiration, these valuable remains, the greater part of which I only perceived from afar; I shall therefore dwell no longer on them herc, than it was possible for me to remain on the places themselves. 
I was very desirous to visit some spacious grottos, cut in the rock, about a league to the west of Gour nei, the sepulchres of the ancient monarchs of Thebes. But I could find nobody who would undertake to conduct me thither; the Scheick himself assured me, that the people of Goumei being at war with some neighbouring villages, a few of whose inhabitants they had lately killed, it would be imprudent to expose myself with guides taken from among them, who, far from affording me protection, would rather be the cause of bringing down upon my head the effects of an implacable revenge.

If the whole day which we passed in a place of such bad repute was somewhat disagreeable, the night was extremely unpleasant. One of the most spacious, and at the same time one of the least substantial cottages had been assigned us, in which we were very closely confined. We had taken every precaution in our power to guard against surprise or attack from without, but not one of us had thought of another species of mischievous beings within doors. Scarcely had we stretched ourselves along our carpet upon the ground, than a legion of rats, of an extraordinary size, covered our apartment; we felt them continually running over us and biting us every moment. This was not all : a very tempestuous wind had risen; our frail cottage could not resist its violence; every now and then 
it blew down large particles, the greater part of which fell upon our bodies. I in particular received upon me a large iron pike which the shaking of our roost tore from the ceiling. If the point had been turned towards me, it must have pierced my body. At length, in the midst of the noise with which the wind deafened us, we heard the tumbling of a wall of the cottage, which very fortunately burst outwards. Fearful of being crushed by what remained, we hastened out of this place of wretchedness and suffering, and passed hulf of the night walking in the open air, with our muskets upon our shoulders.

The Scheick el Belled of Gournei (who in Egypt is the chief man of the place, and nearly the same as the mayors of the villages were in France) had me called to his house. He was afflicted with a disorder which could not be cured except by a difficult operation. I took care not to confess to him that his cure was beyond my skill; I gave him some medicines which could do him neither good nor harm, but from which, however, it was essential to our safety to promise him the best effects.

I found a physician of the country by the side of the paticnt. He for ever carried his knowledge of physic under his arm. It consisted of a large volume written in the Arabic language, containing receipts 
receipts for every discase. Whenever he was consulted, he turned over his repository, and never gave an answer till he had met with a passage which he thought might appiy to the case of his patient. One of my people who was troubled with ague-fits, seemed to address him with a tone of confidence. After being informed of the symptoms which attended the fever, this unpractised physician sought a long while in his book, which in similar cases prescribed acid fruits, such as lemons, pomegranates, \&xc. \&cc. \&x. and the smoke of a burnt fish bone, which the aguish man ought to inhale. But, shutting the book, he added, from his own stock of science, "There is no remedy " more effectual against fevers than written cha" racters;" that is to say, small billets on which certain words are written, and which are either swadlowed or carried about as a charm.

This quack, who had been brought from a great distance to cure the chief of Goumei, did not so much as know his disease, although he had been with him several days. When I had gone away he followed me to ask what I thought of the case. "Look," said I to him, " in your book under the " article fistulas, and you will discover the nature " of that discase, and perhaps the remedy; but " Jose no time, for the gangrene-begins to appear, "and in a very short period your patient will die, 
"if you do not make haste and stop its progreșs." Upon this my sagacious friend, knowing all the danger to which (in his own country) he was exposed, should he fail of a cure, did not long hesitate about forming the resolution which seemed most likely to secure his safety; he did not even revisit his patient, and disappeared without saying a word to any one, but always taking care to carry his knowledge under his arm.

If it was not prudent to travel to Gournei, it was not easy to get away from it. The boats of the Nile shunned its shore, which was an object of general terror; and the malignity of its inhabitants had involved it in war with its ncighbours, and particularly with the people of Komoule', a village about half way to Néguadé, in which they had very lately murdered onc of the natives. According to the savage custom of the country, it was requisite that blood should flow at Gournei to avenge that of Kamoule', without their caring whether this blood, which a blind vengeance sought to spill, was that of the murderer or of any other person. No one dared to expose himself to bccome the victim of a resentment, which time does not obliterate, and which ran only be extinguished in blood. Thus the whole village refused to officiate as guides, and the Arabian Scheick himself was afraid to undertake to conduct us to Néguadé. At last a man appeared, and 
and undertook to direct our course. The Arab supplied us with horses, and accompanied us about a quarter of a league; but notwithstanding all my importunity, he refused to advance farther. We were then left under the protection of a man half naked, walking a-foot, with no other arms than a stick, and whose unfavourable appearance made us apprehensive that we should meet with more like himself. He took us off the plain in order to avoid the vicinity of Kamoule. We climbed those steep mountains which form a chain of rocks along the cultivated districts of Upper Egypt. We passed by narrow straits and irregular windings, through the wildest of deserts, as no trace was to be secn either of men or of animals; and a pile of rocks heaped upon each other, thoroughly concealed the inhabited part of Egypt. A road like this, difficult, and often dangerous for our horses, was by no means adapted to dispel our fears. Our guide, in conjunction with our hosts at Gournei, might have carried us thither to lead us into some ambuscade; however, after journeying for six hours in these unpleasant roads, we descended into the plain near Néguadé, from whence we passed over to Kous. Our conductor followed us thither, and very well satisfied at having escaped his enemies, he was unwilling to expose himself again in their neighbourhood, but followed the Nile with his horses on the castern side, till hearrived opposite to his habitation.

R. 4 


\section{CHAP. LI.}

Copht of Kous-Sheep of Yemen-Sheep of Egypt-. Goats-Hogs-Motives which have induced the Egyptians to exclude these animals from being a part of their food-Crocodile-Lizard-Fragments of ancient stones and glasses-Sinnes antidotes to poison.

I HAD scarcely returned to the apartment which I had already occupied at Kous when Mallium Poctor called to sec me with all the show of friendship, and to congratulate me on my good fortune in having given up the journey to Cosseir, because, as he told me, the Turkish merchant, to whom he thought he might have trusted, had laid a plan to have me robbed upon the road. I did not pay much attention to the conversation of a man with whose treachery I was so well acquainted. The Turkish merchant was no longer at Kous, and I was very sure that if he had been there, and Poctor ab-ent, he would have told me the self-same story of the other with a view to extract some fresh present out of me. But the Copht introduced one rery probable circumstance into his tale, namely, that my Christian interpreter had engaged in the plot contrived by the 'Turk, and Poctor might have 
have added, by himself. I resolved to dissemble; the Copht had influence in the country, and if I could not depend upon the sincerity of his protestations of devotedness aud service, I had reason to fear that he might become a very dangerous enemy.

On repaying his visit I saw in his court-yard several sheep of Yemen, a species the body of which is slender and very long, the head small in proportion to the body, the forehead arched, the ears depending, and the fleece rather short and silky down than real wool. This sheep, though not precisely the same as the adimain or great sheep of Senegal and the Indies, of which Buffon takes notice*, resembles it in so many respects, that the slight distinctions which subsist between these two animals appear to arise rather from local circumstances than from a perpetual variety. Besides, these sheep of Arabia do not form a part of the flocks of Egypt; those which I saw at Kous had been sent to Poctor as curiosities.

A country whose extent is entirely measured latitudinally, whose climate, soil, and even inhabitants present sensible gradations, will naturally contain productions modified by difference of situations. This impression, occasioned by a tem-

* Natural History of Quadrupeds. Ovis Cruineensis. Lin. 
perature more or less warm, and by its aridity or moisture, will also be perceptible in the animals which man has appropriated to himself. The greater part of those of the same species which the Egyptian reared are not alike in the north and in the south. It has been observed, that the race of sheep in Lower Egypt is remarkable on account of the size of their tails, and that they are known by the title of Barbary sheep*. From a mixture of this latter sort with the common sheep, which is very frequent amongst animals of this species living in a domesticated state, in warm climates, an intermediary race has sprung up, and is scattered over Turkey, Grcece, Provence, \&c. \&x. \&ic.

Above Cairo neither the same rams nor the same sheep are to be seen as in Lower Egypt. The race is much stronger and larger. The head of these animals is there proportionally much greater, and the tail mueh bigger, more flattened above and bare below for about half its length. A large fetlock hangs under the neck; their horns are short and crooked, their legs are not so high, in proportion, as in the other sorts; and the testicles of the male sometimes drag upon the ground. A thick fleece quite loads them. When it is sheared they do not touch the wool upon the head, which is soon

* See page 68 of the second volume of this work. 
covered again to the very tip of the snout. This species of bushy curled hair, through which they see with difficulty, gives them a very singular physiognomy. Their colour for the most part is brown bordering upon red, the shade of which becomes clearer as they grow older. Some are black, and others of a yellowish white.

Although these animals grow to an astonishing size, yet their voice is very feeble, and their bleating is seldom audible; they are, notwithstanding, extremely petulant. The rams are butting continually, and even when there are no females among them. Their skin is used for beds by most of the Egyptians. Besides the thickness of the fleece, which renders this kind of mattress less hard, they believe that in sleeping upon them they are secure against the stings of scorpions, which they say never go upon wool, or apparently they would get entangled by it. One of these skins of a full length, that is to say, long and broad enough to serve man as a mattress, was sold as high as twenty-four franks (a pound sterling), whilst the whole animal alive, but stripped of its fleece, only cost from seven to eight franks, from 5 s. $10 d$. to $6 s .8 d$.

The second race of Egyptian rams, also to be found in Nubia and Abyssinia, is very probably that which Buffon has described under the denomi- 
nation of Ram of Tunis;, which description, it must be observed, wants precision, for he does not stifficiently distinguish the species from that of the Barbary sheep, from which it differs in many respects, although Linnaus, or his editor Gmelin, has confounded them, by denoting both as particularly remarkable for the breadth of the tail th.

Neither are the goats alike in the longitudinal direction of Egypt. In the north the goats with sleck hair and long ears hanging downwards, the Mambrina or broad-tailed goat $*$, is the only species which the Egyptians propagate. The goats of the Saild are much smaller; their horns are thin and handsomely turned; they are very spruce and lively, and besides, uncommonly noisy; you perpetualiy hear their bleating, the sound of which cannot be better compared than to the cries of a child. Their hair is long, very bushy, and nearly as soft as silk. This latter charactcristic, and some other similarities in shape, give it a strong resemblance to the silky haired goat of Angora. It appears that this race of goats is the same with that of the goat of Juido, of which Buffon has made mention in the natural history of the wild goat, and which, according to the report of Bos-

* Supplement to the Naturai History of Quadrupeds.

+ Ovis laticaula:a. ISee page 88 of $2 \mathrm{~d}$ Vol. 
man, is common in Guinea, at Angola, and upon some other of the coasts of Africa *.

You do not see amid these flocks of sheep and goats in Egypt an animal of another species, which, in our country, forms one of the articles of rural wealth as well as one of the most common and savoury viands. The legislators of the East, to begin with the priests of ancient Egypt, agreed to proscribe the flesh of the hog. This animal was considered as unclean by the Egyptians in particular. If any one chanced to touch it, merely in passing, he was obliged to plunge into the Nile with his clothes on. Those who kept herds of them form. ed an isolated class who were excluded from the society of other men; although Egyptians themselves, admission into the temples of Egypt was forbidden them. Nobody would give them their daughters in marriage, nor would any one wed theirs $\uparrow$. Nevertheless, whilst the Jews in Egypt who had taken this aversion to hogs never either sacrificed or ate them; the Egyptians sacrificed them once a year to the Moon, and, on this day only, the day of the feast of the full moon, was it lawful to eat them $t$.

* Natural History of Quadrupeds, and Supplement, art . Buck of Juida. Capra reversa. Lin.

- Herodotus, lib. ii. sect. xlvii. French translation of Larcher.

$\ddagger$ Ibid. Notes of Larcher. 
It is not reasonable to belicre that an areision so general amoing a celebrated nation should have no other foundation, as somc people have imagined, than a natural abhorrence to the voracious appetite which leads these animals to wallow in heaps of the vilcst ordure. It would have been necessary for the same reason to reject the flesh of fowls, which, it is well known, greedily devour the vilest and the most disgusting aliments.

The custom of abstaining from hog's flesh undoubtedly originated from the necessity of a strict regimen, indispensable under a scorching atmosphere; and this will be irresistibly evident, when it is observed, that the race of hogs natural to warm climates rather resemble the hog of China, or of Siam and India, than the European hog *; that these hogs of China, even when brought up in our cold climates, afford food, more delicate indecd, but much fatter, than that of the common hog; that this food, very white and relishing, but so fat in Egypt, in Syria, and even in the southern parts of Grecce, oppresses the most robust appetites; in a word, that for these reasons alone, they were induced to consider this animal as pernicious, on account of the indigestion, and of the unpleasant risings which it occasions in stomachs already in weakened by the excess of heat.

* Buffon, Nat. Hist. of Quadrup, - Sus porcus. 
On the other hand, the vast quantity of fat with which this animal is loaded, obstructing the perspiration in climates where the heat produces it so abundantly, renders the Egyptians more liable than elsewhere to the measles, a disease peculiar to them, and which under a burning sky might easily degenerate into a leprosy. Such a disposition as this was more than sufficient to inspire Egyptians with detestation at a species of animal, which appeared to be itself liable to a disease, and to induce them to shun every tendency toward any thing that could generate this abominable distemper. This was, in fact, the real cause of an aversion, which the stupid superstition of the Jews has retained in colder countries, where the hog is among the number of animals most useful as a nutriment of man. The Egyptians thought, that being constitutionally subject to the leprosy, to ringworms, and other cutancous eruptions, which in these parts assume a more decided degree of virulence, it was absolutely requisite to abstain altogether from this sort of food.

Abstinence from the flesh of the hog has been transmitted to the present race of Egyptians. The Cophts never eat it, any more than the Mahometans; so that nothing is more scarce in the Said than this animal, where there are no Greeks, as in the cities of Lower Egypt, who bring it up clandes. tinely, 
tinely, nor any other Europeans, except seven or eight missionaries scattered up and down. Upon my arrival at the convent of Néguadé, in which hospitality is so treacherous, some Catholic Cophts hastened to inform me that I might see a rare and singular animal there. I hastened, in my turn, to request them to show it me. They conducted me to a corner of the yard, and I was surprised to find nothing in it but a pig which the monks. were rearing, and which the stupid Egyptians looked upon as a very curious animal.

These same Catholics, who concentrate the superstitions of various religions, entertain a belief, the effects of which must frequently prove fatal to themselves. They are persuaded that the crocodile *, connoisseur enough to distinguish the Christian from a Mussulman, only attacks the latter, but respects the worshipper of Christ. They are so much prepessessed in favour of this opinion, that they bathe without fear in the waters of the Nile, where these huge and hideous lizards exist; whilst the Mabometans, whose credulity urges them to acknowledge a predilection miraculously occasioned, dare not expose themselves there. I remember to have read something similar to this in the first vo-

* Crocodile, or the crocodile properly so called, lizard-footed, Nat. Hist. of oviparous Quadrupeds.-Lacerta crocodilus. Lin. In Egypt, timsah, a name approaching to that of chamses, which the crocodile formerly bore there. 
lume of a description of Western Ethiopia. The author affirms that the Christians have nothing to fear from crocodiles, but that they devour many of the negroes. Superstition holds the same language every where, and here people of discernment will distinguish that of missions.

In remote times the crocodile experienced a different treatment in Egypt, according to the place in which it was to be found. In one part it was pursued with fury and destroyed wirlout pity ; in another it was an object of veneration. The in. habitants of the environs of Thebes and of the Lake Nœris, regarded it as a sacred animal. They chose out one from among $\mathrm{tl} \mathrm{em}$ which they tamed; they took the greatest care of it; its food was prescribed and regilated by religious books; they adorned it with ear rings made of gold or of fictitious stones, and with a sort of bracelcts on its fore feet*, an attire far too elegant for an animal so hideous.

At present the crocodile is neither destroyed no: reverenced. They are left in peace to impart their musk smell to the waters of the Nile, and to clear them of fishes. Banished to the most southern part of Egypt, they assemble there in vast numbers. They are to be seen when the sun is at its beight,

* Herodotus, place above quoted, $\$ 69$.

VOL. III. 
their head above the water, immoveable, and ap. pearing at a distance like large pieces of floating wood, gliding slowly down with the current, and basking in the heat, of which they are very fond. I have shot several in that situation, and very close to them; for, not being often disturbed, I could approach them casily. With a coat of mail which resists the ball, it is very difficult to kill them. I was in hopes of being able to fracture their skull by a discharge from my musket loaded with a slug; but whether it be that they were equally impenetrable there, or whether, being wounded only, they retired to die some time aftcr at the bottom of the deep, I know not, but all those I shot made a plunge and disappeared immediately.

In the neighbourhood of Thebes, the small boat in which I sailed up the river, was often surrounded by crocodiles, on a level with the surface; they saw us pass by with indifference; they neither discovered fear nor any crucl intent at our approach. The noise eccasioned by musket-shot was alone able to disturb them in their state of tranquil apathy. They never rise upon vessels, and how little socver they may be lifted above the water, nothing is to be apprehended from their attacks. But you must avoid thrusting your arms or legs into the stream, or you will run the risk of getting.them snapped of by their sharp and pointed teeth. 
Very alert in the water, which they cut with rapidity, they make but slow progress on dry land; and were it not that their slime colour, and the bed of mud with which they cover themselves in walking along the miry shores of the Nile, disguise them so as to render them less perceptible, and thus expose you to be surprised by them; they are by no means so dangerous out of the watery element; in which they are stronger and more at liberty.

It is upon the muddy coast of the Nile that they deposit their eggs; it is there also that they copulate. The female, which in the act of copulation is laid on her back, has much difficulty in rising again; it is even said, that she can neither change her position nor turn without the assistance of the male. Will it be believed, that in Upper Egypt there are men to be found, who, hurried on by the excess of an uncxampled depravation and bestiality, take advantage of this forced situation of the female crocodile, hunt away the male, and replace him in a commerce that shocks humanity? Horrible embraces, frightful enjoyments, the knowledge of which should never have stained the disgusting pages of the history of human perversity!

The fecundity of the crocodile would prove a terrible scourge to the country which it inhabits, did not numerous enemies, among which the tortoise of 
the Nille rutuks the foremost, prevent its multiplication by devouring its egers, and the young ones as soon as they were batched. Seren young crocodiles, liatched two days before, were brought to me at Kous; they were eleven inches long, and their teeth were already very sharp. The Egyptian who took them informed me that there were about fifty of them together, but that it was impossible for him to seize them all, because the mother had arrived unexpectedly, and was eager to fly upon him. These reptiles, already so formidable from their hideous form and their voracity, are still more so from their immense length. I saw at the convent of Fieguadé the skin of a crocodile thirty feet long and four broad. I have been assured that some have been found in the Nile even fifty feet in length.

I have also scen at Néguadé the skin, badly preserved, of another species of lizard, which in that couniry is called ouaral*. It was two feet long, but there are some larger. It is entirely a land animal; it never goes into the water. Many fabulous stories are told about it, in which, perhaps, may be included the expedient it makcs use of, according to the report of Sicard, to draw the milk from sheep and goats, of which it is excessively

* The marbled Lacepedes, Natural History of oviparous Quadrupeds.-Lacerta Nilotica. Hasselquitz, İtin. page $3 \mathbf{3}$. Forskal, Fauna Rigyptiaco Arab, page 13. Lin. Systo of Nature.

fond; 
fond; it takes a strong hold of one of the legs of the sheep, or of the goat, with its long tail, and thus preventing them from walking, it sucks them at its ease *.

I received from the Copht Poctor a small bag filled with the fragments of all sorts of brilliant stones, as well as of vitrified scoria, which had becn found among the rubbish of ancient monuments. In presenting me with this treat, of no great value, Poctor made me cibserve a little round flint of at dark yellow colour, and scattered over with diminutive spots perfectly round, of a white tinged with ycllow, and having in their centre a point of the same colour with the ground of the flint. Its property, real or supposed, of curing the sting of scorpions, occasions it to be much suught alter by the Egyptians. But the most precious thing which the Copht possessed, and which he did not give to me, was a very beautiful ruby that he wore upon his finger, and which had been found in the ruins of Dendera.

The flint of which I have been just speaking, is not the only one to which virtues are antributed, that exist on!y in the imagnation of the Eryptians. A little stone was shown to me, which is called the Stone for poison by way of excellence (hudlsjur sem). Powdered down and taken in a small dose, it is con-

* Memoir of Missions to the Levant, vol. v. page r 94 . 
sidered as an antidote against the poison of serpents and of other venomous animals. The quacks of every country make use of this species of stone to deccive the multitude, and in order to give it greater reputation, they say that they have taken it out of the head of a serpent or of a dragon. It is in reality nothing more than a mineral concretion, which owes all its efficacy to superstition and credulity.

This is also the case with respect to the stone of Benazir (hadzsjar Benazir), which takes its name from a viliage near the place where it is most commonly found. The inhabitants of Egypt look upon it as another precious antidote. When it is rubbed against a vessel containing a few drops of water, it whitens them and makes them like milk.

My medical skill was put to a severe trial before my departure from Kous. The new Kiaschef fell from his horse and dislocated his shoulder. He honoured me with a confidence which could not have been worse bestowed. It was in vain for me to point out the established distinction betiveen physic and surgery; it would not have becin understood, and the confession of my inability to relieve him, would not have been without danger. I was obliged then to bccome surgeon; my companions became my assistants. It was a singular spectacle to see us torment the Mameluc by useless efforts, whilst he, not perceiving 
AND LOWER EGYPT.

perceiving our want of skill, was patiently enduring the pain of an operation ill performed. I had reason to fear that my patient would keep me by him; and from the apprehension that this whim should seize him, I departed that very evening for Kerné, where I arrived on the $23 \mathrm{~d}$ July, at night. 


\section{CHAP. LII.}

\section{Kenné - Koft - Dendera-Kelhé - Commotions -} Surges of the Nile-Pirates-Sahet-BélianéBirds - Girgé - Italian monks - Menshié-Guépiers-Tahta-General rebellion in this districtVenercal diseases-Fevers-Worms-Bloody piles -Flies - I Imeumon fies - Scorpion-LiaardsBoat - Kanu-el Kebir - Weevils - Skirmish between the Arabs-Repairs of the boat-Aboutige -Courtezans-Dirt-eaters-Manfelout.

Kenne', an inconsiderable village, is situated, as well as Kons, towards the east, but farther from the Nile; it is a rendezvous to the caravans which rravel to Cosseir, and return from thence loaded with the costly productions of India and Arabin. Its name is not changed: the ancients called it Cenae and Cenopolis, but it is no longer what it once was. A canal, by which the waters communicated with those of the Arabian gulf, rendered is situation very favourable for commerce. Of this canal not a trace remains; the monumiuts which adurned the ancient city are nu longer to be seen; its commerce is nearly annihilated; its riches have vanished, and nothing 
is left of the industry of its former inhabitants but a wretched manufacture of earthen-ware.

Between Kous and Kenné, Koft is situated, a village on the coast, near the spot on which the ancient town of Cophtos stood, and which the commerce of the Red Sea also rendered a flourishing place. Several authors assert that the canal of the Red Sea, now filled up, terminated here, while others place its boundary in the neighbourhood of Kenné.

This last district is opposite to Dendera, which I visited for the second time. I did not fail again to cast a glance of admiration on the temple which the Tenlyrites had consecrated to Isis, a monument in a higher state of preservation than any other in Egypt. I met the same friendly reception from the Emir as before : he presented me with a very bealbtiful antique head of white marble, but I lust this, with a number of otlser curiosities, which werc taken from me.

Continuing to descend along the Nile, whose waves grew more disturbed, and rose into a greater swell every day, we stopped on the 25 th at Reishie, a village on the western bank of the river, where we purchased some provisions. From thence we proceeded to $K e l h e$, another village on the same side, 
sidc, and about half a league distant from Sahet, where I had so many disputes with the Mameluc who commanded there, and with the master of my boat. This spot had almost proved fatal to me. I found it in the most violent state of commotion. Whole villages, iaking advantage of the confusion caused by the war, which was on the point of bursting out in Upper Egypt, had broken out into open rebellion, and refused to pay their tribute, which, uncertain where victory would incline, they were apprehensive of being twice called upon to discharge. Several of these little colonies had taken up arms to resist the Kiaschef of Basjoura, who was marching against them to reduce them to order: that of Kelhé was among the number. Scarcely had we set foot on his territory, when, deceived by our garb, thirty or forty fellaths, armed with lances and sabres, fell upon us. We had advanced without distrust, and were without the means of sufficient defence to resist so numerous a force. I was reduced to the only alternative which remained, to reason with a people who are little susceptible of understanding the language of reason. However, after having inquired why they treated as enemies a few peaceable strangers, I perceived that they had mistaken us for the followers of the Kiaschef, against whom they were arming; it was no difficult matter to undeceive them, and they consented, though not without some trouble, to release us. 
We immediately re.embarked, but it was only to encounter another species of danger. The wind blew strong from the north; the river, whose course is here confined by a ridge of rocks which projects into its bed, was furrowed by deep surges, particularly in thosc places where the rapidity of the current has to struggle, though with superior force, against the resistance of the wind. Having cndeavoured to gain the thread of the current, we found the billows so high and so boisterous, that our little kanja, which had no ballast, was on the point of being oversel. With much trouble and danger wc reached the foot of the mountain, where we remained, in expectation that towards night the wind would subside, which is generally the case.

We had been forewarned at Kelhe, that this place was reckoned the most dangerous passage for navigation on the Nile. No boat ventured here alone; pirates here exercised a continual trade of plundering both day and night. Before our eyes, we beheld one of their most formidable retreats. Several caverns, hollowed out of the rock, served them for a habitation and an obscrvatory, from whence they took cognizance of vessels at a distance, the attack and plunder of which thcy had time to project. In all probability, they considered their number to be at that time insufficient to cope with us. We continued upon our guard, and they 
did not venture to approach us. As they wereso near, however, we could not quit the shore, and I was unable to visit the caves, which are rut ont of the rock, and which, in all probability, are the labours of antiquity.

Although night approached, the fury of the wind did not abate, and it was impossible for us to remain where we were. We, made a kind of sail with some pieces of blue cloth, part of the dress of our sailors, and stcering our course towards the opposite shore, across a swcll, which threatened destruction to our little bark, we arrived at Sahet, a port of Basjoura, and of Farschout.

The Reis went ashore to the village; he immediately returned to inform us, that, in consequence of the disturbances which raged in this district, he lad been assured that we could not remain before Sakek, without running the risk of being murdered. I ordered him to return to the Scheick el Belled, and to acquaint him that I was a Kiaschef; that I laid my injunctions on him to kcep a strict watch over our safety, or that he should be answerable for the consequences. There was no occasion to repeat this message a sccond time; the chief of the village himself, with a few attendants, kept guard the whole night near my boat. At daybreak he was very assiduous in his inquiries whether I had slept 
siept well, and if my health was perfectly good; he then ordered a light brcakfast and some coffec to be brought me. I took my departure, however, with all possible dispatch, lest it should have been discovered, as the day advanced, that the pretended Kiaschef had no beard.

Béliané, a considerable village to the westward of the Nile, and near which, towards the mountains, are still to be seen, as I have learnt from some of the inbabitants, ruins which occupy a large portion of ground, was the retreat where we passed the night of the 27 th.

Storks and pelicans stood motionless for wholc hours on little islands of sand; kings-fishers, black and white plovers, armed, and those with a ring round the neck, and herons, were here and there to be seen; and cren before Bélicmé, pigeons made a descent upon the river, although rapid and agitated, and remaincd some moments on the surface of the water.

From Béliané we bent our coursc on the 28 th towards Girgé. There was here still another hospital of monks for the propagation of the faith, to which I had also a letter from Cairo. I had some curiosity to see whether they were any better than those of Ectunimm and Nésuudé, and the reception 
I met with satisfied me fully as to this point. I prescuted myself before the supcrior, an old man with a long white beard, and rather of a graceful deportment. He satisfied himself with looking at the date of the letter which I put into his hands, and perceiving it was written some time back, he threw the paper in my face, telling me the letter was worth nothing. I confess 1 had occasion for all my patience to restrain myself from punishing such excessive insolence, and of which several people were the witnesses. The monk perceived my agitation; he took up the letter, read it, and began to pour forth a torrent of apologies, which I received by turning my back upon him, and quitting the house, fully determined never to set foot again within these abodes of folly and impertinence.

Next to Cairo, the city of Girgé, which is situated at about the distance of a hundred leagues from it, built along the Nile, the shore of which is there lofty and steep, may be reckoncd the most considerable in Egypt--It is the capital of the Said. A bey resides in this place, and the Cophts there maintain a bishop. The architecture is modern and irregular, and the stranger meets with nothing to attract his attention.

We departed thence on the morning of the 29th. The north wind, which for several days past 
had blown with unabated fury, raised the waves mountain high, and far beyond any thing that I shonld have expected to have seen on a river. It entirely prevented the navigation of the boats which followed the course of the Nile. With considerable difficulty we arrived at Menshié, a town whose markets are always well supplied, because the vessels which steer for the north of Egypt, generally lay in a stock of provisions there. The pigeonhouses are more bcautiful here than in any other place. A large and populouscity, Ptolemais Hermii, was formerly situated on this spot. A few scattered ruins, and a bank of sione to restrain the waters of the river, are the only relics of the ancient splendour of Menshié.

The Kiaschef of this place wished me to visit him in my medical capacity, and inquired if I was furnished with letters from Mourat Bey; on my replying in the affirmative, he told me that I had but an indifferent recommendation, as Mourat was on the point of being dispossessed of his usurped at:thority. This Kiaschef was on the point of forming a junction with Hussan Bey, who was inimical to Mourat, and whose party was becoming every day more powerful in the Said. But the most unpleasant circumstance to me, was the declaration of his intention to take me wilh him, for the purpose, as he said, of curing the wounds shich Hassan had 
received in his last conflict with Mourat. I did not lose a moment in withdrawing from the execution of a project which would inevitably have proved fatal to me, and I look my departure for Souhaje, where I arrived on the morning of the $30 t h$. In the course of this day we observed the same species of birds that I bave just mentioned.

'The next morning I quitted Souhaje on horseback, accompanied by two Arabs, after having left orders that my boat should proceed to Tahic. I passcd through Kéné, a village at the foot of the western mountain, and under the dominion of the Arab Scheick Ismain-Abou-Ali. I saw in the enrirons, under real acacias, some guépiers *, beautiful birds and rapid in flight, which are continually in pursuit of winged insects. They were not in the least degree wild, and as they hopped along, they uttered a small cry, hilil, and only once at a time.

At 'Tuht, where I arrived on the evening of the 3 ist, I resumed the lodging which I had formerly occupied at the habitation of the Catholic Cophts. Mallium Monreous, the Copht, upon whom I had performed an important cure, was at Cairo; my reputation however was high at Takta, and as soon

* The Guépier. Buffon, Hist. Nat. des Ois. \& pl. etilum. No. 935 . - lierops adicster. Liti. 
as my return was known, I was beset by a multitude of invalids, or persons who supposed themselves to be so.

This district was far from being in a state of tranquillity. The fellalis of the surrounding country had risen in a body, and refused the imposts. Some Arabs also, from whom tribute had been exacted, joined themsel res to the malecontents. The several Kinschefs had united their forces to march against the insurgents, and had just sustained a complete defeat. A victory over authority, or rather over the most detestable despotism, had rendered this country a scene of riot and confusion. The fields were abandoned or laid waste: the husbandman forsook his plough to fly to arms; the flocks were carricd off, or dcstroyed, and every sort of provision became the prey of the enemy or of robbers. The highways, lined with banditti, were shut against communications and intelligence of every kind. In a word, dcsolation raged over a soil, the fertility of which struggled against the ferociousness of the inhabitants. All these circumstances caused devastations, which of necessity would be long in repairing, and far above the value of the impositions which they were desirous to levy. But amid the indignation which is excited by a luatcful tyranny, persons are not always able to reflect coolly upon the consequences. The pcople, vol. III. 
however low they may be reduced, become weary at length of heing at the disposal of unprincipled men; and that power which, stifling the dictates of justice and of conscience, leses sight of the privileges of humanity, and has no other recoursc to attain its object, but the rigour of arbitrary violence, cannot exist long, and must infallibly sink under the weight of its own oppression.

The ferv days I passed at Tahta, during which I did not often quit the house, as I was confined there by the troubles which raged in the country, afforded me an opportunity of making fresh observations on the diseases of the country, and the method of cure which the Egyptian physicians employed. They distinguish several specics of venereal diseases, according to the clifference of the symptoms, and they bestow on them whimsical names, which it is no casy matter to explain. The generical denomination is cmbarek (the blessed). Sometimes it is the diserse of goats, and sometimes the disease of camels. This last description is looked upon as the most dangerons, and the most difficult to cure. Nothing is nore simple than their treatment of the diseases: it usually consists in ealing a great quantity of meat, in drinking strong brandy, and in rubbing the body with oil and sulphur. Others recommend a method of cure fully as simple, but much more disgusting: it is to drink the water in which 
which their women wash themselves after lying-in. A man gave me positive assurance, that he had been freed by this means of several external symptoms which had entirely disappeared; but even if this account had been entitled to credit, it was nevertheless certain that his cure was merely palliative; for this very man was constantly complaining of violent pains in his limbs, and particularly in the joints. At Cairo, and in the other cities of Lower Egypt, the treatment is more methodical: they administer for the space of forty days the decoction of sarsaparilla; the regimen consists in eating nothing during that time, except unleavened bread and honey. After that they prescribe large potations of brandy.

I observed that intermitting fevers were very uncommon in Egypt. When they do appear, the symptoms in general only continue for five or six days, at the expiration of which period they either cease altogether, or they become malignant fevers. The Arabian name for ferer is shone. The unwholesome food of the greater part of the inhabitants generates an immense quantity of worms in the intestines; the Egyptians of the Said call them feisousé. There are few men in this country who are not subject to the bloody piles: when they swell and become very painful, they are 
usually opened with a razor. It is the province of the barbers to perform this operation.

Besides the enormous quantity of common flies, which torment both men and animals in this scorching climate, I observid another species very like the common $\mathrm{fly}$, only smaller; its body is entirely covered with hair, and of a blackish brown colour, deep and shining. These flics were brought to my boat in a basket of fruit.

Another description of flies, whose head and body are of a bright green, with a little black at the extremity of the body, and some small transversal streaks of the same colour under the belly, are frequenily to be seen at Tahta; I observed them since at Rossetta, where they disappear during the winter season. These flies in general remain on the ground, where they feed upon every thing they meet with, fruit, the remains of rictuals, excrement, \&c. \&c.

In Upper Egypt you meet very frequently with a beautiful species of the ichneumon $\mathrm{fly}$, which only appear in the lower country during the sumsner months. Some of these are of a blue and violet colour, with brilliant golden reflexes, and others of a sparkling golden green. A long sharp sting projects from the extremity of the belly. 
These benutiful insects, which I saw again at Rossetta, although ouly in the inild season, enter the houses and take up their abode in litile holes of the wall and in the wood. When they are caught, they discharge a small quantity of a liquid which has the smell of sulphur.

One evening, on the tcrace of a house, at a small distance from my own hahitation, I heard screans of agony which lasted for more than an hour. On inquiry, I learnt that they proceeded from a woman who had just been stung by a scorpion. A female was concerned, and this circtimstance was sufficient to prevent my receiving any intelligence of the consequences of the wound.

At this season little lizarls of uncommon beauty throng on the shorcs of the Nile, and in little pools of water. Gold and azure glitter in long fillets over their whole body, and their tail is of a beautiful sky blue. Those beautiful lizards likewise approach, though not often, the habitations of man. I perceived one on the wall of a house where I lodged at Tahta. Excessive heat is necessary to the propagation of their species, and in fact I never met with them in the north of Egypt. The Egyptians secmed to entertain a kind of veneration for these little animals, for as I endeavoured to catch some of them with a stick 
upon the shore, the sailors of my boat frequently entreated me to desist.

I had discharged the kanja which brought me to Tahta. To prosecute my journey, I waited till some boat should touch in the neighbourhood. I had been informed that there was one at Scheick Zeineiddin, a small village on the banks of the Nile, and a little below Tahta. I proceeded thither, and I confess I was a little alarmed when I beheld the disposition of the machine on which I was about to embark; it was one of those large vesscls which they call masch: its lading was corn for the supply of Cairo, bui it was so full that it lay even with the vater's edge, and in order to prevent the entrance of the water, they had erected on the gunwale a bastion of fascines and of mud. If a journey by land had been practicable, I should have taken good care how I set foot in a vessel, the arangement of which was only suited to persons who had nothing to lose, or to such as possessed unconmon facility in swimming. But the whole country was a scene of tumult, and no person dared venture to travel through it. I departed then, on the 6th of August, in this ressel; its lading, already so heavy, was farther increased by a great quantity of men and of sheep, which they stowed cven on the top of the corn. 
About two lcagues from Scheick Zeineidin, and on the opposite shore, that is to say to the castward of the Nile, the villace of Kan ol Kethir (Kin the great, to distinguish it from the smaller village on the opposite side), which is built upon a lofty promontory, presents to the eye and the regret of the traveller, the ruins of an ancient colonnade, in a good state of preservation. A bank of freestone, half decayed, repels the attacks of the current against the territory of this ancient city, which some steppose to be Antropolis (the city of Antaus), and others Diospolis IIinor (the lesser Diuspolis). At the very point of the cape and before the haven, you may sce the vast rcmains of a mole, which the waters hardly coscr, and which, projecting into the middle of the river, renders this passage extremely dangerous. When the watcr is low, this piece of architecturc, also built of freestone, appears above the surface of the river, and gives an air of probability to the conjecture, that in this spot there was formerly a bridere over the Nile.

The master of the boat was a native of Tomieh; lie did not wish to pass this town without paying a visit to his family and his habuation, and above all, without laying in a stock of com for his own use : he caused a tolerably large proportion to be conveyed to his house; and lest the lading of his vessel should appear diminished, he took care to 
mingle as much dried earth with the mass as he had piliered of the grain.

As I walked by the Nile I discovered on the rocks some wecvils, about ten lines in length and fuur in breadth; their colour is a dark ycllow and tinged with a blackish huc.

We were the spectators of a conflict between two parties of Arabs at a small distance from the Nile. Althongh the fire of masketry continued for a considcrable time, it was by no means fatal. We did not see a single person drop; they fired at a distance, and almost always on full gallop. It was a slight skirmish between bad marksmen, mutually endeavouring to shun each other. After a full hour employed in an exercise, which appeared to be a tilt for amusement rather than a real engagement, we saw one of the parties retire without the shadow of a cause, and as composedly as if they werc rcturning from a fesival.

The Reis appeared to be quitc at his ease, and seemed to give himself very little trouble about the boat, the direction of which was intrusted to him. The anxiety I experienced was extreme; the disorders which raged on land prevented my removing from my present situation, and the numerous assemblage by whom I was surrounded in 
the boat. renclered my situation there neither more secure nor more agrecablc. At length we took our departure on the 8th, carried along by the violence of the wind and waves. The billows dashed with fury against the feeble barrier which they had erected on the bark, and there was every reason to apprehend that by softening the mud which supported it, it would be very soon overset.

At the moment of our departure we saw a village on fire; it was called Koum el Arab. This conflagration was the consequence of a war among the Arabs, in which they discovered neither valour nor generosity, and every act of which was stamped with a treacherous and cruel revenge.

We halted at Alioutigé. Repairs were necessary to our boat. What I foresaw had come to pass. The bastion of mud, which was erected on the edge, had yiclded to the fury of the waves; the earth, entircly softcned, had in scveral places opened a passage to the svater; the fronts of the fascines had fallen down, and if we had proceeded much farther on our voyage, the waves infallibly would have washed over the vessel and sunk her. The sailors began to rebuild this feeble barrier; but as this was a labour which required sume time, I cmbraced an opportunity which presented itself of proceeding to Siout by land.

A Turk, 
A Turk, who was an officer of the houschold of a bey, dispatched to collect his imposts in the country, and forced to return empty handed, in a moment of universal rebellion, offered to conduct me to Sicut. He was obliged to take his departure the day after we arrived at Abouligé. That he might not be detained by me, I passed the night in a caravansera. I had scarcely composed myself to rest, when several discharges from a musket were fired with rapidity in the middle of the building where I was. Every body ran out; for my part I remained perfectly composed, and I was informed that the alarm procecied from robbers, who were endeavouring to break into the house.

I had passed part of the day in a coffec-house at Aloutige, with the Turk, and two Serraths of Cairo, who, contrary to the usual character of peopie of this kind, were courtcons and affable. According to custom, we were entertained with poets and female dancers, equally devoted to the worship of Venus. They formed a kind of corporation, under the inspectivis of a police officer, to whom each member is ubliged to pay ten medinas every Friday. This man, whose Arabian name signifies Commander of the Prostilutes, exercises unl:mited authority over these women; he protects or punishes them according to circumstances. 
Although such as I saw at Allontigé were far from being ugly, they inspired disgust, by the disenses with which they were eaten up, and the traces of which were to be seen even on the faces of many of them.

Between Abnuigé and Siout a canal is to be seen, which the Nile already filicd with its waters. We were on horseback, and our guides had imagined that we might cross it nearer the chains of mountains, where they supposed the water would of course be more shallow. But having found the passage impracticable, we were obliged to return the same way we came, coasting along the canal, as far as the bank of the river. There we found a little boat, constructed of old pieces of wood, joined together with mud, and into which we had considerable trouble in getting cur horses to enter. At length we arrived at Siont about mid-day.

During the journev, I observed that my compa. inion the Turk stoppect from time to time, and gave orders to a servant to pick up some pieces of clirt, which he immediately devoured. I inquired what relish he could possibly have for such a singular repast. He informed me, that an invincible appetite madc it necessary to him, and that nothing in the world could prevent him from gratifying it. This man was about sixiy ycars of age. Allhough 
Although he was corpulent, his colour was yellow; he was fecble and languid, and complained of violent pains in his stomach. Born in Constantinople, and having passed a considerable part of his life in Turkey, he had only felt this inclination to eat dirt, after a pretty long residence in Egypt. I have been since informed, that several persons in the same country were attacked with this malady, for it is of a species which appears peculiar to Africa. It is well known that the negroes who were brought into the American colonics, frequently perished from the consequences of this inordinate appetite, after passing a life of pain, and tortured by unavailing stripes, and barbarous precautions which they found means to elude.

From Siout, where I left the dirt-eater, I proceeded on the evening of the I ith to Manfelout. The next morning the boat, which I had quitted at Aboutigé, made its appearance; my companions and my goods were still in safety; but we were very well plcased to lcave a vessel in which it was both dangerous and unpleasant to procecd. 


\section{CHAP. IIII.}

Turkish Aga-Medicine of the Egyptians-Army of Cairo-Mussulman priests-Bread of lentilsLizards-Boat-Diagon-flies-Gnats and water-spinners-Winds-Eoyptian sailors-Mountains-Unpleasant adventure, and the method by which the author extricated himself-Chains of mountains, and observations respecting themQuarry of white lime-The pelican-PyramidsBirds-Dër Ettin.

While I waited till a boat should make its appearance, less inconvenient than the one we had just quitted, I hired a little house at Manfelout, the rent of which was no higher than at Siout. I had not been here long before I was loaded with disagreeable and troublesome occupations, which it was impossible for me to avoid. A Turkish Aga, who represented the feeble authority of a Pacha of Cairo, resided at Manfelout. He laboured under a languishing disease, and insisted on my visiting him in the capacity of physician. IIe did not seem however to stand in need of persons of this profession, for I saw several at his house, whom he had collected from all quarters, and 
and whose various prescriptions he had the perese. verance to follow one aifter another, and frequently at the same tirne.

Onc of these plysicians ordered him to apply the cast skin of a snalice, under lis turban, a celebrated preservative and specific in Egypt for discases of the head. 'The remedy' which another prescribed for his complaint, was to go out on foot and walk inte the comntry, till he should fall in with a rag, no matter of what sort, which he was to drag along with his naked foot till he reached his housc, where he was to take three sticks and a small quantily of alum, and burning the whole together, to inlale the smoke. A third had assured the Aga, that in three days he would cure him of the complaint in his stomach, under which he laboured. His treatment consisted in mbbing the stomach, and pressing it violently, and alterwards in squeczing it tightly with bandages. I witncssed the resignation of the sick man under this tiresome operation; but the plyysician, very prudently, took his departure before the expiration of the three days which he had required to efiect the curc.

In other respects this over-credulous Aga was of considerable service to me. The army of Mourat Bey, commanded by a bey of his houschold, and along 
along with it the most unbounded licentiousness, entered Munfelout during my residence there. Amid hordes of superstitious and ungoverned barbarians, a Franc ran the greatest risk possible. By one of those abuses of power which civilized nations connive at; by one of those acts of tyranny, too common among men in a state of war, that is to say, in a state of rebellion against nature and the social compact, I was displaced by a detachment of Mamelucs, who took posscssion of my habitation. Omar Aga, so my paticnt was called, as soon as he was informed of my unpleasant situation, caused my effects to be conveyed to his house, and was earnest in providing me with a lodgring there. This Turk was really a good man, but superstitious to an excess. Hc was not satisficd with consulting all the quacks in Egypt, but all clay long there was a number of priests by his side, who read chapters of the Alcorin, or rehearsed prayers. I confesi I was often tempted to laugh, when I observed the astonishment which thesc stupid j) reachers of the Alcoran discovered as they gazed at me. An Europcan, a Franc, was, in their eges, a curiosity; and being an infidel and a reprobate, was supposed, of course, to have something extraordinary about lim. Their looks followed me, and remained invariably fixed upon me. Every siep, erery movement appeared to them wonderfully strange, and thcy could not possibly conceive 
how I came to conduct myself like the true believers. "Sce," said they among themselves, "how he walks, how he moves his hands, how he " eats, \&c. \&xc. IVell, this is truly diverting!"

At the end of a few days, Nanfelout was delivered from the army of Cairo: I saw it embark on the Nile, in a disorder not casy to be described. The bey who commandal was also charged, in his march, with the subjugation of the Arabs, and the fellahs, who had revolted, and refused to pay tribute. The fury of this civil war, laying waste the country, had diminished the sources of abundance: provisions were no longer to be had at the moderate price which was usually paid for them. The poorer classes consumed bread of lentils, to which they added a littic barley; its colou is a golden yellow; it is by no means bad, but it is heavy. They call it betton. Towards the cataracts of the Nile there is scarce any other bread in common use, bccause corn is rery rare in this country, which is the southeria extremity of $\mathrm{Egjpt}$; a little lower, however, it is the sastenance only of the poor.

A multitude of littlc gray lizards * loved to approach the habitations of man. They are to be seen, in a greater quantity than at any other sea-

* Lèzard gris. Lacepede, Hist. Nat. des Quadrup. ovipares. -Lacerta agilis. Lin. 
son of the year, on the walls, and even in the houses. This species is common over all Egypt ; it is there called bourse. Its cry, which is frequently repeated, is not unlike the noise which we make, when we loose the tongue hastily from the roof of the mouth. It is an animal which is sacred both among the Turks and the Egyptians, and the veneration which they entertain for it, doubtless, is connected with the exercise of that hospitality which is now generally adopted in the East. They are unwilling to injure harmless and innocent animals, which approach man with confidence, and which seem to take up their abode with him solely for the purpose of purging his habitation of a sivarm of insects, which constantly torment him in those countries, where the excessive heat renders them more numerous and more troublesome than in other places.

By the attention of Omar Aga I was soon in a condition to pursue my journey. The reader may recollect that, as I proceeded up the Nile, I observed at Manfelout a kind of corvettc, which could only be navigated during the swell of the river. The waters had attained a sufficient height ; they had just finished her lading, and she was on the point of taking her departure for Cairo. This large boat, which they called galioun (vessel), on account of its size, and the port-holes with which VOL. III. 
it was pierced for the reception of cannon, was capable of containing an immense cargo for a river: there were on board two thousand five hundred bags of corn, weighing about two hundred and frity tons, besides a quantity of bales shipped by private hands, at least a hundred men, and sercral head of cattle. On the stern they had erected three beautiful apartments, one of which was much larger than the great cabin of the Alalanta frigate. That on the poop was the most pleasant, and this the Aga had appropriated to my use.

I cmbarked on board this vessel on the evening of the $24^{\text {thi }}$ August. Several dragon-fies*, of a purple colour, flew about the banks of the river, while swarms of gnats and water-spinners, as night approached, tormented us with their number and their stings.

All night long the wind blew strong and cold from the norti. I have read somewhere that no wind is ever felt on the Nile; it is a palpable mistake, for high winds frequently blow there, which swell into tempests and hurricanes dangerous to navigation.

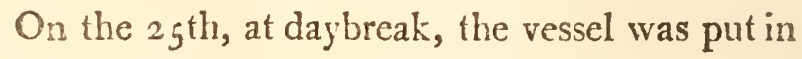
motion, but it did not long continue so; they halted again about two hundred fathoms below * Libellusla. Lin. 
Manfelout, in order to take a quantity of buffaloes on board. I soon perceived the aivkwardness of the crew in mancuvring the vessel. We ran aground near the shore, and they were obliged to labour the remainder of the day, and all night long, before we were clear again. After that, we dropped a little below the spot where we got ashore, in order to take in the buffaloes. We remained here again a complete day and night. In the night, however, our ignorant and improvident seamen having neglected the necessary precautions in mooring the boat, the wind, which blew violently, drove her from her cables, and she floated down the stream at the mercy of the waves. Our danger was imminent; we were close to the mountain of Aboufeda, a complete ridge of rocks on the bank of the river, and against which the current was with violence impelling us. The unskilfulness of our seamen could not fail to make us uneasy: in effect it was after many awkward manœuvres, that we were fortunate cnough to rcgain the shore from which we had broke loose.

At length, after the expiration of several days which had interrupted my voyage, we took our departure on the morning of the $27^{\text {th }}$. Our vessel requiring a great depth of water, we lay close in with the chain of rocks of Aboufeda, in order to have the advantage of the greatest draught, the 
river being confined in its current to this particular spot, it flows along with great rapidity, and the greatest precaution is requisite in stcering the boats along. If they are untortunate enough to split against these rocks, which are more than perpendicular, as the mass is hollowed in the declivity, it is impossible for the crew to escape. Besides the catacombs which I have mentioned, I observed, at the extremity of the mountain of Aboufeda, the ruins of buildings cut out in the rock, and which I had not rcmarked on my first excursion. Several wild geese were perched on the protuberances of the rocks.

Among those persons whom the Reis had put on board, there were four soldier's servants who had Itun away from the army. Well pleased at escaping from the toils of war, their insolence had no bounds. Having been informed that we were Europeans, their insults and impertivence were parficularly pointed at us. I had determined to chastise them at the first town where we should stop; but having arrived at Mellavoui in the night, I was obliged still to restrain myself. The four unruly gentlemen continued their invectives the following day. They carried their audacity so far as to strike two of my companions; the latter were not long in returning the blow; the engagement began, and guessing from the noise what had happened, 1 hastened 
hastened to the spot with my sabre in my hand, and applied a ferv strokes to the shoulders of the aggressors with the flat side. They immediately quitted their hold; but an exclamation was heard over all the boat. An infidel to strike a Mussulman! It was an offence unpardonable, and which threatened me with instant death. They were talking of throwing me overboard. The Reis, instead of appeasing the tumult, as great a fanatic as the rest, cried louder than any of them. I retired with my companions into the chamber which we occupied, and we entrenched ourselves as well as we could, fully expecting to be attacked. The fire-arms, however, with which we were supplied, appeared to the desperadoes who surrounded us, formidable enough to prevent their approach, and they contented themselves with murmuring and concerting plans of revenge.

Through the lattice of my chanhlor, I perceived at Sineick Abadé, the ruins of Anlinoe, and on the same castern coast, Benihassan, a village at the foot of a mountain of rock, rising perpendicularly, in which the ancients have hollowed out sepulchral caverns. A little tower and a forest of palm-trees form a beauliful contrast with the rugged aspect of the rocks which border this bank of the Nile. The village of Savouadi succeeds to this. There the ruins of several ancient buildings are perceptibie. 
The rock has been carved and hollowed in various places; the entrances of a vast quantity of catacombs are arranged over the front of the mountain, and rear them I observed hierogiyphics and symbolical figures.

The vessel dropt anchor at Miniet. The Reis immediately disembarked with about twenty of the passengers, and made the best of his way to the Kiaschef, in order to prefer a complaint against me, for having had the audacity to strike a Mussulman. 'These wicked people took care to relate every fact, and to represent it in the worst light possible. The populace of Miniet thronged in crowds; a flock of fanatical barbarians demanded the head of the $\log$ who had abosed a favourite of Mahomet. I had dispatched my two Egyptian servants after the Reis, in order to observe what might come to pass. They returned to acquaint me with the ferment which the accusation of the Reis had raised in the minds of the people; they had advanced into the court of the house of the Kiaschef, where an assembled mob were calling for vengeance, and they had heard it reported, that I was to undergo the punishment of the bastinado on the soles of the feet. I had not a moment to lose after this information. It was necessary, they said, either to conceal myself or to make my escape. I could not, with propriety, have 
have chosen either of these alternatives: I trok a resolution directly opposite. I determined to face the danger, and to present myself openly, in order to avert it. I quitted the boat immediately with one of my attendants; my habit prevented me from being recoguised. We passed through scveral streets. Every where the topic of conversation was the Franc who had beaten a Mus. sulman. I arrived at the house of the Kiaschef; I penetrated through the crowd, who little supposed that the person on whom their thoughts were employed was in the midst of them; at length I stood before the Kiaschef. An imminse number of persons surrounded him. The Reis and my other accusers stoud forward and pointed me out to the commandant. "Is it you, then," said the Kiaschef to me in the most angry tone imaginable, "who was audacious enough to offer vioJence to a believing Mussulman ?" "Give no heed, I replied, in a determined tone, "to the vain clamour of these paltry fellahs, to whom, for the honour of a valiant Mameluc, you have already paid but too much attention. You are the slave of Mourat Bey; you know very well that I am his friend; I have some important intelligence to communicate to you from him ; attend." I immediately approached, and pretending to whisper in his car, I slipped a few chequins into his hand, which I held ready in my own. 
The Kiaschef, who had raised himself a little from his cushion to hear what I had to say, now took his seat again, and darted menaring glances at the Reis. "You know not," said he to him, with anger feigned, or at leat purchased, what a Frane is." He then pronounced a long and absurd encomium on the qualitics and the power of the Francs, which he knew nothing at all about. The Reis wished to reply; but the Kiaschef rose, and bestowed on him a hearty box on the ear, and then ordered him to receive several blows with a canc. In an instant this mob, ignorant and foolishly habituated to despotism, after having regarded me as the greatest criminal, dispersed, crying up the justice of the Kiaschef, and extolling the excellent qualities of the Francs.

Corruption in men of exalted stations, which is an undeniable tcsimony of the clepravity of manners, and a certain presage of the fall of empires, and the dissolution of the bonds of socicty, appeared among the despots of Egypt to be customary, and a system universally adopted. They were unanimous in opinion, that with the assistance of money crery thing might be obtained * Too great sacrifices, even in this respect, were not requisite to obtain the object desired. It is only in those countries, where they are continually

* Pretio tutum iter et fatens. 
speaking of virtue and of honour, and where, in fact, they do not ?exist, that the price of corruption is an effect of a considerable commerce to which ferv people can attain; but it is moderate in those places where honour not being in common use, it is unnecessary to distribute gold to purchase silence. I had just experienced a signal act of justice, which, considering the manners of the people of Egypt, and the circumstances under which I had obtained it, might have passed for injustice. A single minute lhad proved sufficient to appease the most furious anger, and to make its effects recoil on those who had provoked it; and, nevertheless, it had only cost me from seven to eight chequins.

Whatcver protection I had reccived from the Kiaschef in public, I did not conceive it prudent to place myself again at the mercy of the rabble on board the boat. The four runaways who had oceasioned the disturbance and made the greatest uproar, in truth were no longer in the vessel; the Kiuschef had arrested them. Nevertheless there still remained the Reis and several othersentirely devoted to him, who might have assisted him in taking vengeance for the well-merited chastisement he had just received. I had accordingly made my arrangements for quitting so vile a society, and for waiting another opportunity. The Kinschef to whom 
I had impartcd my resolution, opposed the ezeed tion of my plan with all his might; he enjoined me not to derange myself in the slightest clegree, assuring me by the Prophet that nothing unpleasant should befall me. Tivo officcrs of his househola? were charged with conducting rae back to the boat. As I walked along to reach my chamber at the poop, the Reis and Egyptian passcngers kept a profound silence, but there was no difficulty in dis. cerning that it was the silence of fear and of rage. The two Mamelnes passed the night with me, and, according to their instructions, signified to the $R$ is that he was to look upon me as a man under the protection of Mourat Bey, and that he should answer with his head for my safety and tranquillity, both to the Bey and to the Kiaschef. At the same time, in the name of the latter, they orderedseveral Mameluc officers on board another boat which sailed in company with us, to take care that no insult should be oifered to me. It was agreed, that, in case of any improper procecdings, I should display my schale at the poop, and that they should instantly come to my assistance. I had no occasion, for the remainder of my voyage, to have reconrse to cxternal force. A few murmurs excepted, which I cared not for, my tranquillity was not at all disturbed, and I conld cojoy in peace the satisfaction which I felt in having extricated myself, with so much success, from an adventure which might 
have proved fatal to me, and in having: escaped a punishment which once appeared unavoidable.

At some distance below Miniet, the chain of mountains to the eastward of the Nile, projects into the river, in a mass of rocks lofty and perpendicular, and causes in the waters a confined and rapid current. It is the mountain of birds, which I have already taken notice of *. On the summit of one of the piles of rock of which it is formed, some solitary Cophts have established a monastery but little calculated to soften its rugged and wild appearance.

An immense cut separates this file of rocks from another which they callDsjebel Keranat (mountain of piles), because in truth the masses of stone appear to be piled one above another.

We halted on the evening of the 3 oth near a district covered with date-trees. This natural grove would have appearcd beautiful in any situation; but in the neighbourhood of barren mountains, which weary the sight, and scare the imagination, it appeared truly delightful. As soon as we had dropped anchor, the Mamelucs who sailed in company with us, came to inquire if I had any ground of complaint; they obliged the Reis to

* See page 35 of this volume. 
apologize to me for the insolent remarks which he still allowed to be made. I rer eived his excuses with contempt; but I "as not sorry to see this man, after endeavouring to do me so much mis. chief, completely humbled in my presence.

We weighed anchor early in the morning of the following day. Towards noon, bowever, the wind blew so violently from the north, and the river became so agitated, that the two boats were obinged to seek shelter near an island called Hadsjar Salamé. I had never before seen the waves of the Nile swell so high: breaking short, they even threatencd danger to small decked boats. These boats have no other resource, when overtaken by these tempests, but to present their poop to the surge, and to endeavour to kecp in this situation, which does not always prevent them from being upset.

Continuing on the 3 rst to descend the Nile, we sailed again by a chain of rocks, which the waters touch for a considerable space, and which appear to have experienced some convulsion. At the summit, a chapel indicates the burying-place of a holy Mussulman, universally revered under the name of Siheice Embarek. All the mountains to the eastward of the Nile are more clevated than those to the westward; they are also much nearer the river, the shore of which they frequently form of them- 
selves: but toward the west, the mountains are much farther removed, and sometimes to so great a distance, that they are scarcely perceptible from the river. The former, that is to say, those which are washed by the Nile, project above, while the middle and lower parts retire, being furrowed lengthwise over the whole front which borders the Nile to the very summit, as if the waters had flowed to this height against their declivity, and had there marked the successive diminution of the elevation of their course. Another general observation which the navigation of the Nile enabled me to make, is, that when these mountains, or rather these masses of rock toward the east, confine the current of the Nile, the shallows or sands on the opposite shore advance also to a point, and leave a very narrow channel to the river, which is exceedingly formidable to navigators.

The Nile began to diffuse over the plains her fertilizing waters. The canals were successively filling. The part of Egypt where I then was, may be reckoned the most beautiful country in nature; that where the eye embraces situations the most picturesque, and contrasts the most striking. Towards the west, the country produces an abundance, which ages of cultivation have not zhausted. Villages upon eminences surrounde: with water, appear with the trees which 
which encompass them, like so many verdant islands, floating on the surface of a tranquil bason. Towards the east, barren mountains, masses of rock, heaped one above another, and devoted to cternal sterility, present a forbidding uniformity, unless where their clefts display little cottages situated at small distances, and spots of ground covered with various kinds of plants, particularly with the sugar-cane, whose green and beautiful colour is very plcasant to the sight.

We sailed past Feshne, a market-town on the western shore, which gives its name (Dsjebel Feshné, mountain of Feshré) to a mountain, not so high as those which I liave just mentioned, but longer. It also renders the navigation more dangerous, because having undergone some commotion, several fragments of the rock have loosened and rolled into the river.

The ist of September a dead calm kept us the wholc day before Bébé; we departed thence on the $2 \mathrm{~d}$. The chain of mountains of Feshné, whieh had diminished into little hills of sand, rises again below Bébé, and forms a very high and rounded cape, which confines the course of the river : they call it the mountain of Abounour, from the name of a saint, whose burying- $\mathrm{p}^{\prime}$ the base. We passed $B e$ 
Here the Nilc extends itself to a vast distance, and forms an immense sheet of water, above which habitations and pieces of cultivated ground appear to fioat.

Before Bousch, the chain of mountains toward the east is rounded into a.projecting point, and higher than the adjacent masses in the same chain. This point is white, particularly in those parts which have been worn by the current of the water, and where the surface is of a dazzling whitc. It is called Dsjebel Guypsè (mountain of plaster). A considerable quantity of plaster is, in fact, extracted from it, which they convey to Cairo in long barges, extremely well constructed, and carrying only one square sail.

On the approach of night the vessel was moored opposite to a village called Meimoum, built at some distance from the shore. I observed some pelicans skimming along the surface of the water, and I remarked that the flight of this bird is interrupted; that is to say, it flaps its wings from eight to ten times in succession; then it hovers in the air; again it beats its wings, and so alternately during the whole of its flight.

Opposite to Meimoum, on the eastern coast, there is an old convent of Cophts; and somewhat 
what lower a point of rocks, known by the name of Dsjebel Nouti (the sailor's mountain), because of an Egyptian mariner who is buried there, and whom his companions have canonized.

Riha was our last station before we arrived at Cairo. The inundation was extending itself to the westivard, as far as the base of the immense pyramid, which is risible several leagues from Rilu. As far as I could form a judgment at the distance I then was, it appeared to be erected upon a hill, which was itself of a pyramidical form. The summit appears to be broken. There is also a little village on one side.

Water-fowl seemed to be less common than in that season when the Nile returns to its bed. But if they do not appear so frequently on the river, it is doubtless because the plains being inundated, they extend themselves over a greater space. Above the tops of lofty mountains, birds of prey are secn hovering in great numbers; these are peaceable retreats to them, where they build their nests in the holes of the rock.

Scarcely had the morning of the $4^{\text {th }}$ begun to dawn, when the eagerness of the crew to arrive at Cairo urged them to sprcad two immense sails on the boat. 
boat. We dropped anchor in the evening, about half a league's distance from Old Cairo, before a Cophtish monastery, called Dër Ettin (monastery of figs). It is there that the vessels which come from the Saïd disembark their passengers and their cattle, in order that they may appear in the ports of Cairo with nothing but their cargo. 


\section{CIIAP. LIV.}

Glance on the expedition of the French into EgsptJourney from Cairo to Rossetta-Watering-machines-Loss of several amimals-Altack on the consul of Rossetta by the Bedouins-Birds of pas. sage-Hedge-hog - Frogs - Receds - Mastich Ramadan-Departure from Alexandria.

More than five months spent in travelling over Upper Egypt, that is to say, an extent in latitude. of about a hundred and eighty lcagues, watered by the Nile above Cairo, and tcrminating at the Cataracts, or at the Tropic, and a frequent residence in the principal parts of this country, may have given me sufficient information to deliver my opinion on the late expedition of the French. There are so many people who speak on this subject, with out knowing any thing of the nature of the soil and of the climate of Egypt, or of the manners of its inhabitants; there are so many eulogists, as insipid as they are ignorant; there are so many detractors of a dishonest character, that perhaps some degree of interest will be excited by the frank and open declaration of an observer, jealous of the glory and the power of his country, to whom slavish adulation, and the gloomy sourness of the malecontent, are equally 
equally unknown, and who cannot be denied the privilege, whether he be attended to and consulted or not, at least of speaking out with some confidence on a subject of which he has taken pains to make himself master.

It may have been observed in the course of this work, that I looked upon the project of substituting in room of our distant and perhaps insecure colonies, anothcr colony whose proximity to the mother-country, the almost miraculous fertility of the soil, its adaptation to agriculture, its singularly favolirable situation which renders it the medium of the commerce of the wealthiest nations, its vicinity to countries abounding in the most costly productions; in a word, whose speedy means of communication render it of far higher importance; I say, it may have been observed that I looked upon this project as a sublime thought, as the happiest of conceptions, and its execution as one of those uncommon acts which shed a lustre on nations, and which hears upon itself the evident stamp of immortality.

Infallibly the possession of Egypt will secure to an enlightened and industrious nation the commerce of the Levant and of Barbary, and that of the wealthy land of Yemen. The Indian seas, rolling their waters with violence across its sands, display the practicability of a navigation, and of a 
commerce, the sources of wealth incalculable, particularly when the canal of junction between the Nile and the Arabian gulf, one of the most considcrable and useful labours of the kings of ancient Egypt, shall be discovered and dug upafresh. The river itsclf, better known in its course, will see all the obstacles which impede its navigation disappear, and will waft along without danger, and at a small expense, gold, and the other productions which nature forms under the burning climate of the interior of Africa; whilst the Moor, with his scorched visage, the univearied broker of those sultry regions, shall quit the route of the coasts of Africa, and conduct his caravans into Egypt, as soon as he is certain of being in safety there, of finding protection as well as abundance of the objects of which he makes his refums. Connexions founded on commerce and on interest, but disengaged from all ambition of religious conquest, the pious mania of indiscreet missionaries, and which has excluded the natives of Europe from an immense and important country, may be formed with the Abyssinians, whose possessions are watered by the same river. New accumulations of wealth will discover themselves with new nations; and extending these connexions by degrees, the knowledge of a part of the globe will be attained, into the bosom of which the herocs of antiquity, as well as the most daring modern adventurers, have been hitherto unable to penetrate. 
In speaking of discoveries, I have pointed out the only species of conquest which philosophy adopts, and which neither occasions the shedding of blood nor of tears; that alone which produces pure en. joyment, and which an enlightened nation places in the first rank. The scicnces and the arts also shall find in Egypt a repository, a nursery; and the riches which shall flow trom thence will have a destination more ample, more generous, since their distribution will extend to every nation of the globe.

Agriculture will assume a new form ; and being better understood, it will add the treasures of abundance to the accumulation of wealth alrcady so consider.:ble. I have enumerated its principal productions; I have pointed out such as may be cultivated with success, and the reunion of which promises to eclipse the most valuable commodities of the wealthiest colony. The limits of fertility will be enlarged at least as far as to the chains of mountains which scem to mark its boundary on both sides of the Nile. Nay, perhaps, industry, guided by science, may discover the means of raising vegetation on the sandy and desert plains, which behind these mountains extend themselves to the east and to the west. 
But the consequences which would infallibly ensue, under farourable circumstanees, have becn prerented uuder those which have accompanied the French expedition into Egypt. War is universally allowed to be the greatest impediment to the establishment of colonics. Like a devouring conflagration, it consumes, it destroys every thing which it approaches; commerce, agriculture, every source of public prosperity, is dried up or annibilated; the bright flame of the torch which the genius of the arts and sciences displays to enlighten mankind, grows pale at the spectacle of public calamity, and is at length extinguished in the tears which misfortune crery where causes to flow. The pestilential breath of ambitions passions stifles the voice of philosophy; all good vanishes; every species of woe accumulates. Instead of waters producing fruitfulness, the earth is inundated with blood, the fertility of which is dreadful. Ravage succeeds to cultivation, and famine takes the place of abundance. Misfortunes of every kind throng the stage of the theatre of desolation and blood which war rears; and the man of scnsibility, with a wounded spirit and a heart oppressed with sorrow, feels his indignation roused against atrocious wretches, who in the pursuits of ambition make a cruel sport of the life of men, and whose ferociousness has no counterpart in nature; the ifigers at least never revel in the blood of their cwn species. 
No real happiness can exist independent of peace; svithout it no society can prosper. If these incontestable truths are applied to the expedition into Egypt, it will be an easy matter to discern that the new colony, desolated by the double plague of an intestine and external war, can never attain a flourishing condition. The various tribes which inhabit it, and which perhaps ought to have been disposed for revolution rather than attacked as cnemies; animated by a fanaticism extravagant, because it is founded on the grossest ignorance, and inflamed besides by the enemies of France and of the general repose, abandon the cultivation of the ground or lay waste the crops, if any have been produced. The fields are trampled under the fect of warriors, and all the horrid preparatives for carnage; plains, which a succession of ages had seen arrayed in haryests the most copious, with wonder behold themselves overshadowed by tents. The labours which the military art requircs operate only to the detriment of that of agriculture. Scveral points on the surface of the earth change their appearance and their nature, and it is easy to conceive how prejudicial these partial dcrangements must be in a country where fertility is, if I may use the expression, merely factitious, and where it cannot exist at all without the aids which the people of ancient Egypt have multiplicd with so much skill and judgment.

$$
x 4
$$

The 
The devastation which the necessities of a large army must require, and military labours of every kind, are su many wounds given to agriculture. The trees, which are so valuable in Egypt, where wood of every description is extremely scarce, will fall beneath the hatchet of necessity or of malevolence; the destruction will ensue of the ancient plantations, a necessary asylum against the heat of the climate, and of groves always verdant, and loaded with sweet and refreshing fruits. . By this means, at a moment when peace shall be restored, it will be requisite to repair the ravages of war and of barbarism, before any plans of improvement can be carried into execution; an immense undertaking, but not too difficult for the courage and activity of the French.

An excessive heat, particularly in the southern extremity of Egypt; the hurricanes of the south rolling along clouds of dust and of flames, may appear inconveniences sufficicntly serious to deter individuais from an inclination to inhabit the new colony. But the coolness of the night relieves the scorching heat of day, and the southern impetuous gusts, which are certainly attended with danger, very seldom arise. There is no ancient colony but what presents greater discouragements; but there is no one which possesses more numerous advantages. The climate is by no means unhealthy. 
With a litlle precaution, a person has the prospect of living to a great age, and free from complaints of every description, excepting the diseases of the cyes, which are in a great measure unavoidable.

In Lower Egypt the climate is not so severe. Rains and waters diffused in the greatest abundance, produce more freshness over the immense and humid plains, than the barren mountains either contract or dry up with a scorching reverberation. The manners of the people, like the climate, are less harsh, and the traveller is there exposed to far less danger.

With what satisfaction did I find myself again in this country, which appeared in my eyes a tranquil abode, when compared with the Said, and in which commerce had induced several Europeans to fix their residence! I did not however see again my fellow-countrymen at Cairo; 1 had too strong an impression on my mind of the anxiety which I experienced in the narrow limits to which fear confined them. Besides, the neighbourhood of Cairo was in the greatest agitation; the beys had cncamped in the environs, and were preparing to march their forces against the enemy who threatened an attack from Upper Egypt. I hastened orer the spots which were occupied by a horde of soldiers, under no discipline whatever, and favoured 
by my disguise, I passed through the middle of them without attracting their attention. Leaving Cairo on the right, I proceeded to Boulac, in the expectation of finding a boat to convey me to Rossetta; but they had all been retained for the service of the army. I fell in with a reis however, the same who brought me from Rossetta. He had left his kanja at Beissous, a village below Boulice, bing apprehensive that it would have been taken from him. We travelled by land as far as Schoubri, another village between Boulac and Beissous, and departed thence in a small shallop to join the boat.

We quitted Beissous on the 6th September, at eight o'cleck in the evening, by the unclouded light of the moon. It was something new to us to enjoy tranquillity again, afier having been deprived of it for so many months. IVe were no longer torn with the decp anxiety which never ceased to prey upon our minds during our journey through the Said. There were, it is true, several pirates of the Nile in these latitudes also; but besides the smallness of their number, they were exceedingly thinorous, and hardly cver ventured to attack vessels when they suspected Europeans were on board, being apprehensive of their fire-arms. The masters of the boats, accustomed to navigate for the commerce of Europe, were in general persons worthy of confidence; and the waters of the river, unconfined 
by a steep shore or mountains of rocks, are never agitated by the conflict of a rapid current and the impetuosity of the wind, but flow along smoothly and unimpeded, between two low and slimy banks, against which the boats are in no danger of being dashed to pieces.

The farmers of this part of Egypt never employed for the watering of their land the same swipelevers which are to be seen above Cairo. Industry has there made a greater progress. They make use of a sort of wheel with a chain-pump, which is turned by oxen, and which, raising the waters of the Nile, diffuse them over the plains or the adjacent gardens. But whether it be that the construc. tion of these hydraulic machines, although exceedingly simple, appears too expensive to be undertaken by husbandmen in general, or whether they are unwilling to multiply them, being only employed for temporary waterings; I saw them put in practice besides another sufficiently singular mode of conducting the water over the cultivated lands. Two men seated on the bank of the river, at a certain distance from one another, hold each the cnd of a rope, in the middle of which is fixed a couffe or basket of rushes; by means of a constant balancing motion which they give the cord, the basket is filled with water, and at the extremity of 
the arch which they make it describe, it empties itself into the furrow prepared to receive and con. duct it.

The passage from Beissous to Rosselta was not long; we arrived there on the 7 th, at six o'clock in the morning. I found again the persons who had shewn me so much friendship, during my former residence in that city, but none of the animals which I had left there were alive. I was informed that they had all perished sereral days before my arrival, excepting one antelope, which seemed to have escaped solely to enable them to exact the amount of the hire of the place where these animals had been shut up, as it was necessary that they should have died but a little before, in order that it might be in their power to make me pay for the expense of feeding them.

Some time after my departure from Rossetta, the consul, whose polite attention to me was uniform, had been attacked on his return from Alexandria by the Bedouins. They were not content with plundering him; they offered violence besides, and more than once threatened to murder him. They kept him till the erening, as well as his servant, stretched upon the sand, and exposed to the scorching heat of day. It was suspected that 
these Bedouins belonged to the tribe of Hussein, the very one which had conducted me, with so much good faith through the desert of Nitria, and defended me with such valour against the attacks of another tribe. The precaution which they took of tying a bandage across the eyes of the consul's servant, who had accompanied me in my journey over the desert, was a presumption of some weight, and which perfectly coincides with what I have mentioned respecting the customs of this wandering and extraordinary nation, with whom virtue is allied to plunder, and who pillage and protect alternately, according to circumstances.

I: was the season for the passage of those birds which at the approach of the frosts quit our icy countries, during a part of the year when nature is in a state of torpor or of death, in scarch of climates less severe, and of a plentiful supply of nourishment. From the month of August, they catch near the coasts of Egypt, and particularly in the neighbourhood of Alexandria, an immense quantity of fig-peckers *. The passage of these little birds

* Becfigue, Buffon, Hist. Nat. des Ois. et pl. enlun. No. 668. fig. I.-M Motacilla ficedula. Lin. It is not to be supposed that all the birds which are taken in large quantities on their arrival at Egypt, are real fig.peckers; there are to be found among them stveral little birds of different species, such as the fauvette, which is frequently mistaken for the fig-pecker. 
lasts about three months, during which period the Egyptians catch them in great quantities, by rub. bing bird-lime on the trees and bushes upon which they settle. They sell them either alive or plucked. In order to strip them of their feathers, they bury them for a moment in the sand, the heat of which, by melting their fat, renders it an easy matter to pull out the feathers, and prepares them to become a very delicate repast.

I remarked more particularly at Rossetta and at Alexandria, some other species of birds of passage during the month of September, the period when the absence of these new guests of a country more mild, transforms our naked forests into gloomy solitudes. The bird which fills our groves with his shrill whistling, as it cmbellishes them with his brilliant plumage, the loriot * perches himself, from preference, on the mulberry-trees of the gardens in the environs of inhabited places; but he does not utter his sonorous roice; he is silent in Egypt; he has not there to sing his lores. He serves for food, and his passage is little more than fifteen days. They likewise eat guépiers † (wasp-eaters), which the Provençals name sirenes, and the Grceks

* Loriot, Buffon, Iist. Nat. des Ois. et pl. enium. No. 26 . -Oriolus galbula. Lin.

† Guépier, Buffon, Hist. Nat. des Ois, et pl. enlum. No. 938.-Merops agiaster. Lin. 
melisò orglï, (bec's enemy). But this is not a highly esteemed species of food. There are likewise flycatchers*, which are caught with a net or with bird-lime. Another bird, less delicate still than those of which I have been just spcaking, and which is not less the victim of the voracity of man on its arrival on the coasts of Egypt, is the red speckled magpie + , called by the Arabs dagnousse. and by the Provençals darnagua. They are caught in nets in pretty large numbers. They are sold alive, as wcll as all those birds which the law of Mahomet forbids to be strangled, and which must not be used for food till after they have been bled. But as these latter are very vicious, and as they cruelly nip the fingers, the bird-catchers take care to tie together the two ends of their beak with one of their feathers. You see there likewise rolliers + , which the Provençals call blurets, woodpeckersई, \&zc. \&ic.

But there is no passage of birds more considerable, and at the same time more unaccountable,

* Gobe inouche, première espèce, Buffon, Hist. Nat. des Ois. et pl. enlun. No. $5^{6} 5$, fig. 1.-Muscicapa grisola. Lin.

$\dagger$ Pie griêche rousse, Buffon, Hist. Nat. des Ois. enlum. Nos. 9 et 3:-Lanius colurio. Lin.

¥ Rollier d'Europe, Butron, Hist. Nat, des Ois.-Coracias garrula. Lin.

$\S$ Pic-vert, Buffon, Hist. Nat.des Oir. er pl, enlum. Nos. 37 t et $879 .-1$ 'icus virilis. Lin. 
than that of the quails. They arrive and re-assemble on the sandy shores of Egypt in very numerous companies. It is difficult to conceive how a bird, whose flight is heavy, and which cannot long continue on the wing, which we see alight in our fields almost as soon as in motion, should venture to traverse so vast an extent of sea. The islands which are scattered over the Mediterranean, the vessels which sail along its surface, serve them indeed for resting-places and for shelter when the winds become stormy or contrary to their direction. But even these asylums, which the quail has not always strength enough to reach, and the distance of which frequently occasions its loss, prove also places of destruction to it. Too much fatigued to escape, they permit themselves to be taken easily upon inhospitable shores; they are caught without difficulty by the hand on the rigging of ships; and when excess of weariness prevents them from rising high enough to perch upon it, they dash violently against the hull, fall back, stunned by the shock, and disappear in the waves. Whatever may be the dangers of a long voyage, which these birds seem unqualified to perform, whatever diminution of number the troops of these feeble travellers may undergo in the passage, there arrives, notwithstanding, so great a multitude in the neighbourhood of Alexandria, that the quantity to be seen there is really past belief. 
The forvlers of Egypt catch them in nets. During the first days after their passage, such numbers are on sale in the markets of Alexandria, that threc, and sometimes four, may be bought for a medina, or for fifteen or sixteen deniers (not three farthings). The creirs of merchantships were fed upon them; and there existed at the consul's office at Alexandria several complaints preferred by marincrs against their captains, for giving them nothing but quails to cat.

In walking over the gardens of Rossetta, a hedge-hog was pointed out to me, which in Arabic is called confhess: This quadruped is common in Lower Egypt, but in Upper Egypt it is not to be met with. The neighbouring pools were filled with thousands of frogs, which make a terrible noise. The reeds among which these reptiles conceal themselves at the bottom of the water, serve to make ropes, which are in general use.

I found the same idea prevailed at Rossetta as in the Said, respecting the property ascribed to the smoke of mastich: but with this citference, that in Upper Egypt it was considered as being absolutely mortal to the sick who inhaled it; -whereas at Rossetta it was only looked upon as

* Erinaceus Ezroficús.

VOL. III. 
being pernicious to them. For this reason, the sick, in order to avoid the danger of breathing this fume in a country where mastich is frequently burnt, are careful to hold an onion constantly under their nose, the odour of which, if it be more wholesome than that of mastich, is undoubtedly much less agreeable. All the mastich which is consumed in Egypt is brought from the island of Scin, in the Archipelago. The women con: stantly eat small pieces of it melted with wax, they mingle it in ragouts, and they perfume with it those vessels which are set apart to cool water in, as well as almost every houșehold utensil.

The Ramadan or fast of the Mussulmans began this year on the $22 \mathrm{~d}$ September. In the evening I saw the ceremony of its opening at Rossetta: all the tradesmen assenble together in companies, and march in procession through the city, lighted from iron pois carried upon the point of long sticks, in which chips of resinous wood are kindled. The chicf of each of these corporations of mechanics, ncunted upon a beautiful horse, is decked in an cxtraordinary garb: several of them also wear vizors. The people grcatly applauded this masquerade, but expressions of joy and approbation were particularly audible when the chicf nightman appeared disguised as an European. This fact may convey a 
proper conception of the respect in which we are held in this part of the world.

It is not only unlawful cither to eat or drink during the month which the Ramadan lasts, from the rising to the setting of the sun, but it is as strictly forbidden to chew or even to smoke tobacco. The labouring man, overcome by fatigue and by the heat, parched with thirst, is yet farther reduced by cmpliness. But the severity of a long fast has nothing oppressive to the man of wealth; he can in every place elude the laws; the poor man aione is oppressed to the full exient of their exectition. If the Ramadan is a period of fasting very difficult to be borne by him who is supported by his labour, it is an era of pleasure to the opulent; they make a lent aud a carnival of it at one and the same time. As soon as the sun is set, feasting, dancing, music, spectacles throughout the strects succeed to the rigid abstinence of the day. The idle and useless man thus passes the night amilst diversions, and sleep prevents him from perceiving the lapse of time.

After having rested a few days at Rossetta I returned to Alexandria, where I resumed my ordinary clothing, to which it was some time before I could again accustom myself. A vessel of the number of those appropriatcal to supply caravans, 
or to the coasting trade along the scas of the Le. vant, was preparing to sail for Smyrna: I took this opportunity of finding, my way into Greece and Turkey. I separated from all my companions, whose task was to finish with the expedition through Egypt, excepting him who was particularly attached to me. The vessel on board which I cmbarked sailed from the new port of Alexandria on the 17 th of October 1778 , and I soon lost sight of the flat and naked regions of a country, where the prodigies of art seemed to vie with the wonders of nature.

THE END. 


\section{UNIVERSITY OF CALIFORNIA LIBRARY}

\section{Los Angeles}

This book is DUE on the last date stamped below.

\section{DISCHARIGE-URI}

MOY
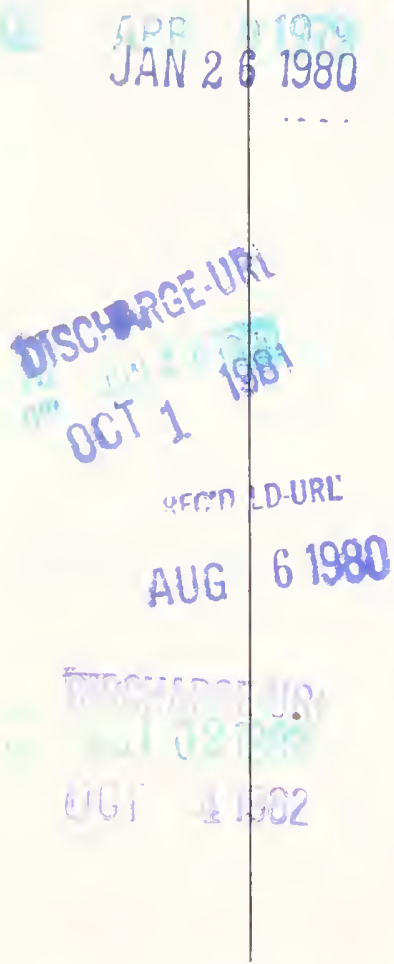

DHE 2 WKS FROM OATE RECEIVED

OCT \& 01990 kistontand NOV $281990: 11^{7}$
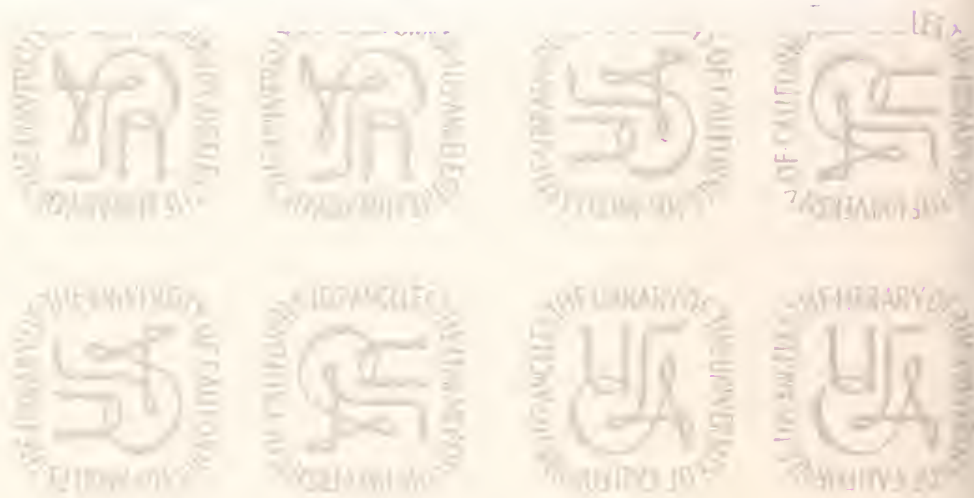
